\title{
MCNP-4B Validation for the DFS System at SRS
}

by

A. Blanchard

Westinghouse Savannah River Company

Savannah River Site

Aiken, South Carolina 29808

O. Rivera

WSMS

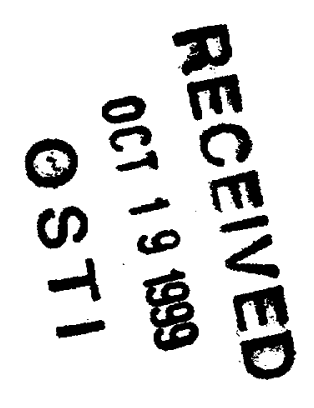

This paper was prepared in connection with work done under the above contract number with the U.S. Department of Energy. By acceptance of this paper, the publisher and/or recipient acknowledges the U. S. Government's right to retain a nonexclusive, royalty-free license in and to any copyright covering this paper, along with the right to reproduce and to authorize others to reproduce all or part of the copyrighted paper. 


\section{DISCLAIMER}

This report was prepared as an account of work sponsored by an agency of the United States Government. Neither the United States Government nor any agency thereof, nor any of their employees, makes any warranty, express or implied, or assumes any legal liability or responsibility for the accuracy, completeness, or usefulness of any information, apparatus, product, or process disclosed, or represents that its use would not infringe privately owned rights. Reference herein to any specific commercial product, process, or service by trade name, trademark, manufacturer, or otherwise does not necessarily constitute or imply its endorsement, recommendation, or favoring by the United States Government or any agency thereof. The views and opinions of authors expressed herein do not necessarily state or reflect those of the United States Government or any agency thereof.

This report has been reproduced directly from the best available copy.

Available to DOE and DOE contractors from the Office of Scientific and Technical Information, P.O. Box 62, Oak Ridge, TN 37831; prices available from (615) 576-8401.

Available to the public from the National Technical Information Service, U.S. Department of Commerce, 5285 Port Royal Road, Springfield, VA 22161. 


\section{DISCLAIMER}

Portions of this document may be illegible in electronic image products. Images are produced from the best available original document. 
Westinghouse Safety Management Solutions

Criticality Technology Group

July 6,1999

\section{MCNP-4B Validation for the DFS System at SRS (U)}

Manager:
Originators:

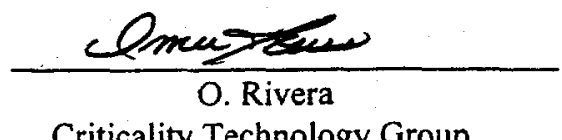

Criticality Technology Group

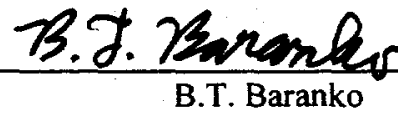

Criticality Technology Group

Technical Reviewer:

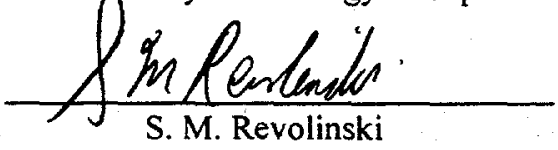

Radiological \& Spent Fuel Engingering

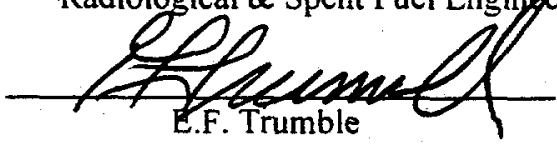

Criticality Technology Group
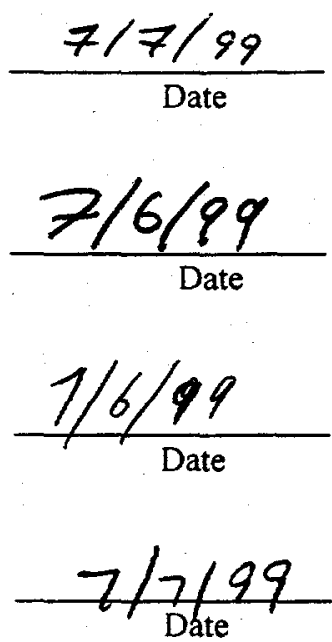

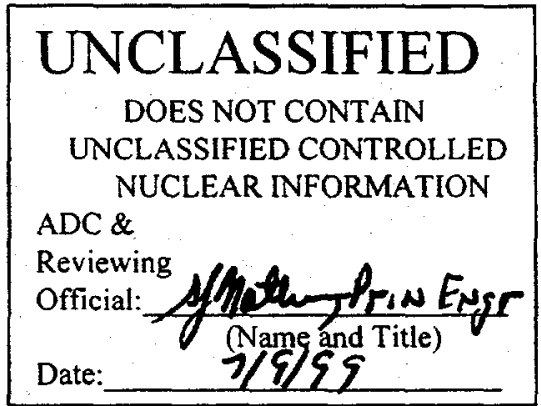

Distribution
C.E. Apperson CCC-3
L.A. Hedlund 707-F
F. Beranek $\mathrm{CCC}-3$
WSMS/CRT Files
B.T. Baranko CCC-3
S. Revolinski CCC-3
K. Yates
730-2B
Records 773-51A
D. Biswas
$\mathrm{CCC}-3$
O. Rivera
$\mathrm{CCC}-3$
A. Blanchard
M.A. Rosser 703-F
J. Bryce
707-C
J. Brotherton
730-B
B.R. Kerr
M. Harris 707-C
D.Dolin
$\mathrm{CCC}-3$
E.F. Trumble $\mathrm{CCC}-3$
N.J. Jordan 707-C
M. Nadeau 707-C 


\section{$\begin{array}{ll}4.0 \text { PLUTONIUM SYSTEMS } & 7\end{array}$}

4.1 PLUTONIUM METAL

4.1.1 Area of Applicability

4.1.2 System Description

4.1.2.1 Single Unit Plutonium Spheres

4.1.2.2 Arrays of Plutonium Metal Cylinders

4.1.2.2.1 Unmoderated Button Array

4.1.2.2.2 Unmoderated Cylinders Array

4.1.2.2.3 Moderated Cylinders Array

1.2.3 Flooded Arrays of Plutonium Metal Cylinders

4.1.2.3.1 Flooded Array of Cylinders (Phase I)

4.1.2.3.2 Flooded Array of Cylinders (Phase II)

4.1.3 Bias and Uncertainty

4.1.4 Limitations

4.2 PLUTONIUM SOLUTION 16

4.2.1 Area of Applicability 16

4.2.2 System Description $\quad 16$

$\begin{array}{ll}\text { 4.2.2.1 Unreflected Spheres } & 16\end{array}$

4.2.2.1.1 Unreflected 16-Inch Diameter Spheres 16

4.2.2.1.2 Unreflected 18-Inch Diameter Spheres 18

4.2.2.1.3 Unreflected 48-Inch Diameter Spheres 18

4.2.2.2 Water Reflected Spheres 19

4.2.2.2.1 Water Reflected 11.5-Inch Diameter Spheres 19

4.2.2.2.2 Water Reflected 11.5-Inch Diameter Spheres Partly Filled 21

4.2.2.2.3 Water Reflected 12-Inch Diameter Spheres $\quad 22$

4.2.2.2.4 Water Reflected 13-Inch Diameter Spheres 23

4.2.2.2.5 Water Reflected 14-Inch Diameter Spheres $\quad 25$

4.2.2.2.6 Water Reflected 14-Inch Diameter Spheres with $4.05 \%$ and
$4.40 \%{ }^{240} \mathrm{Pu}$

4.2.2.2.7 Water Reflected 15-Inch Diameter Spheres $\quad 27$

4.2.2.3 Water Reflected 9, 10, 11, and 12-Inch Cylinders 28

4.2.2.4 Reflected Slabs of Plutonium Nitrate $\left(\mathrm{Pu}\left(\mathrm{NO}_{3}\right)_{4}\right)$ Solutions $\quad 30$

4.2.3 Bias and Uncertainty $\quad 32$

4.2.4 Limitations $\quad \cdot \quad 35$ 
5.1 URANIUM METAL

5.1.1 Area of Applicability 36

5.1.2 System Description 36

5.1.2.1 Single Unit Systems.

$\begin{array}{ll}\text { 5.1.2.1.1 Unreflected HEU Spheres } & 37\end{array}$

5.1.2.1.2 Natural Uranium-Reflected Pseudosphere, Pseudocylinder, and Parallelepipeds

5.1.2.1.3 Unmoderated, Reflected HEU Spheres $\quad 39$

5.1.2.1.4 Water-Reflected HEU Spheres 44

5.1.2.1.5 Moderated, Reflected and Unreflected HEU Slabs 45

5.1.2.2 Multiple Unit Systems

5.1.2.2.1 Hemicylinders $\quad 47$

$\begin{array}{ll}5.1 .2 .2 .2 \text { Tinkertoy } 1 & 49\end{array}$

5.1.2.2.3 Tinkertoy $2 \quad 50$

5.1.3 Bias and Uncertainty 51

5.1.4 Limitations $\quad 52$

\subsection{RESEARCH REACTOR FUEL}

5.2.1 Area of Applicability $\quad 53$

5.2 .2 System Description $\quad 53$

5.2.3 Bias and Uncertainty 53

5.2 .4 Limitations $\quad 55$

5.3 URANIUM SOLUTION $\quad 56$

5.3.1 Area of Applicability $\quad 56$

5.3.2 System Description $\quad 56$

5.3.2.1 Single Unit Unreflected Cylinders of Uranyl Nitrate 56

5.3.2.2 Single Unit Concrete-Reflected Cylinders of Uranyl Nitrate

5.3.2.3 Single Unit Plexiglas-Reflected Cylinders of Uranyl Nitrate

5.3.2.4 Concrete-Reflected Arrays of Uranyl Nitrate Cylinders 60

5.3.2.5 Plexiglas-Reflected Arrays of Uranyl Nitrate Cylinders 60

5.3.2.6 Uranium Oxyfluoride $\left(\mathrm{UO}_{2} \mathrm{~F}_{2}\right)$ Solution Experiments $\quad 61$

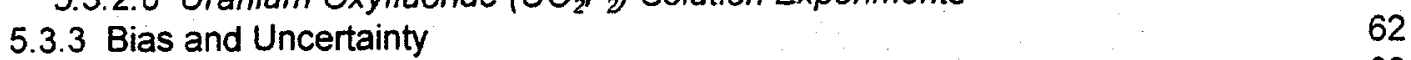

5.3.4 Limitations 63

5.4 URANIUM COMPOUNDS (LOW ENRICHMENT)

5.4.1 Area Of Applicability 64

5.4.2 System Description $\quad 64$

5.4.2.1 $\mathrm{UO}_{2}$ Rods at $2.35 \%$ and $4.31 \% \cup-235 \quad 64$

5.4.2.2 $\mathrm{UO}_{2} \mathrm{~F}_{2}$ Solutions at $5 \% \quad 65$

5.4.2.3 Uranium Nitrate Solutions at $10 \quad 65$

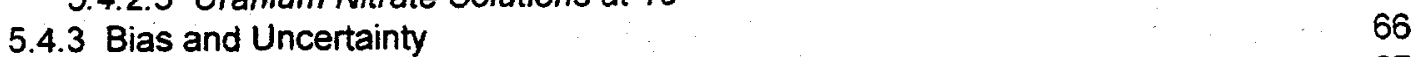

$\begin{array}{ll}5.4 .4 \text { Limitations } & 67\end{array}$

6.0 REFERENCES $\quad 68$

APPENDIX A: WSMS MCNP-4B Validation Results

APPENDIX B: Comparison of WSRC and WSMS MCNP-4B Validation Results 85 


\subsection{INTRODUCTION}

ANSI/ANS Standard $8.1^{1}$ requires that computer codes and methods used to determine limits for criticality safety be validated against experiments. This document provides the current work to date on the validation of the WSRC certified ${ }^{9}{ }^{10}$ MCNP-4B code, and is the last stage of the WSRC Validation Plan $^{3}$ that was drafted to guide the validation effort.

\subsection{WSRC MCNP-4B Validation}

Given the fact that MCNP-4B has been validated on the WSMS DEC Alpha machines in the Centennial Complex, it was desirable to determine if such validation could be used to efficiently document the SRS MCNP-4B validation on their RS/6000 workstations. For this, a representative sample of input files from each of the major fissile types and forms were run under the SRS certified MCNP-4B code and subsequently compared to their WSMS counterpart. The results of these comparisons demonstrate that the two platforms provide statistically similar $\mathrm{k}_{\text {eff }}$ and uncertainty values without the introduction of a bias. This gives sufficient certification that the validation for MCNP-4B under the WSMS system is directly compatible as the MCNP-4B validation for the WSRC system. Table 1 in Appendix B shows the results of this comparison. Based on this comparison, it is appropriate to use the bias and bias uncertainties generated by the WSMS workstation when evaluating corresponding cases generated by the WSRC system.

The input files for the SRS MCNP-4B validation experiments can be found in the $/$ raidl/packages/crit/Validation/Mcnp4b directory on the WSMS DEC Alpha workstation platform, while the output files are saved on a compact disk held by the owner of the WSRC MCNP-4B Certification Notebook'. The remainder of this document (with the exception of Appendix $B$, and formatting such as page numbering) is identical to the WSMS MCNP-4B validation document, authored by N. J. Jordan and M. N. Eakin.

\subsection{WSMS MCNP-4B Validation}

This validation utilized the MCNP-4B control sequence, with the ENDF/B-V cross section library, running on the WSMS Digital Equipment Alpha Processors (DEC Alpha) UNIX workstation cluster under the Network File System (NFS). The values of bias and bias uncertainty are presented for uranium and plutonium systems. For each fissile system, the area of applicability of the validation is presented, followed by a brief description of the benchmarks that was used in the determination of the bias. Following this is a discussion of the bias and bias uncertainty and the limitations of the validation. This document does not present values of $\mathrm{k}_{\text {safe }}{ }^{4}$, as these are system dependent. The limits presented in this document encompass the bias, the uncertainty due to reported experimental parameters, the statistical uncertainties in the calculation of the experiments, and the uncertainty associated with geometrical or modeling uncertainties in the computational method. 
When used with a margin for Area of Applicability, and an appropriate subcritical margin, the value of $\mathrm{k}_{\text {safe }}$ for a particular application can be determined ${ }^{4}$.

Table 1.A presents a quick reference guide for the complete list to date (as of 5/19/99) of technical reports and calculation notes.

Table 1.A Technical Report and Calculation Note List.

\begin{tabular}{|c|c|c|c|}
\hline \multicolumn{2}{|c|}{ Experiments } & Tech Report / Calc Note & Originator \\
\hline$\overline{P U-M E T-F A S T}$ & $\begin{array}{c}001-006,008-011 \\
016-017,022-023,037\end{array}$ & $\begin{array}{l}\text { Contained within this } \\
\text { document. }\end{array}$ & - \\
\hline PU-SOL-THERM & $001-007,009-012$ & $\begin{array}{l}\text { Contained within this } \\
\text { document. }\end{array}$ & - \\
\hline HEU-MET-FAST & $\begin{array}{l}001-004,007,012,013 \\
021-024,026,033-035\end{array}$ & WSMS-CRT-98-0063 & G. Kessler \\
\hline IEU-MET-FAST & 005,006 & WSMS-CRT-98-0063 & G. Kessler \\
\hline HEU-MET-THERM & 006 & $\begin{array}{l}\text { Contained within this } \\
\text { document. }\end{array}$ & \\
\hline HEU-SOL-THERM & $001-003,007-012$ & WSMS-CRT-98-0070 & G. Kessler \\
\hline HEU-COMP-THERM & $011-014$ & WSMS-CRT-98-0070 & G. Kessler \\
\hline LEU-COMP-THERM & $001,002,010,017$ & N-CLC-H-00314 & T. G. Williamson \\
\hline
\end{tabular}

Section 2 provides an overview of the calculational methods used in computing the $k_{\text {eff }}$ values for the critical benchmarks and the MCNP-4B analytical sequence. Section 3 provides an overview of the methodology used in the validation and in the generation of the bias and uncertainty. Sections 4 and 5 provide detailed discussions of bias and bias uncertainty for each fissile material. Appendix A provides the calculated $\mathrm{k}_{\text {eff }}$ and statistical deviation as well as validation parameters for each critical experiment. The input files are not included in this compilation. For input files and a more detailed description of the experiments and statistical analyses, refer to the individual calculation notes and/or to the International Handbook of Evaluated Criticality Safety Benchmark Experiments. The input/output files for the systems compiled in this validation document can be found in the /raidl/packages/crit/Validation/Mcnp $4 b$ directory.

\subsection{CALCULATION METHODOLOGY}

MCNP-4B is a general-purpose, continuous-energy (or multi-group), generalized geometry, neutral particle and electron Monte Carlo transport code developed at the Los Alamos National Laboratory. The code is applicable in two modes: criticality and external source modes (the source mode is primarily for shielding evaluations). Monte Carlo can be used to calculate the system multiplication factors $\left(k_{\text {eff }}\right)$, the energy spectrum 
for neutrons and photons, and the reaction rate distribution. This validation incorporates the criticality mode to calculate $\mathrm{k}_{\text {eff }}$.

\subsection{BIAS AND UNCERTAINTY METHODOLOGY}

The methods used in this document to determine the value of bias and bias uncertainty for a particular area of applicability are given in Chapter 6 of the Criticality Methods Manual $^{4}$. In Chapter 6, the bias methodology is subdivided into different approaches depending on the amount of data and its characteristics. In this report, the upper subcritical limit and lower tolerance limit are used.

The upper subcritical limit (USL) is determined from a non-parametric analysis of a nonnormal distribution of data. The USL is a limit determined from the smallest observed value in which a certain fraction of the true population of data is expected to lie above for some degree of confidence. A lower tolerance limit (LTL), on the other hand, assumes that the distribution of the data is normal, and thus a single value of $\mathbf{k}_{\text {eff }}$ can be determined, above which a specified percent of the data will fall with some confidence. A LTL cannot be extrapolated, and thus is only valid within the range of the experimental data. A LTL is typically used when a good fit (or correlation) cannot be found between an independent parameter and the calculated $k_{\text {eff }}$ values.

For all reported LTL values in this report, a confidence and population level have been set at 95 percent. Thus the LTL's represent values that 95 percent of the population will lie above with 95 percent confidence. For USL's, the percent of the of the population that will lie above with 95 percent confidence will be determined by the number of data points. Table 1.B contains a summary of the biases for each set of experiments.

Table 1.B Summary of limits for each system.

\begin{tabular}{|c|c|c|c|}
\hline EXPERIMENT (\# OF CASES) & TYPE OF LIMIT & LIMIT VALUE & PAGE \\
\hline PU-MET-FAST (5I) & Lower Tolerance Limit & 0.990 & 13 \\
\hline PU-SOL-THERM (91) & Upper Subcritical Limit & 0.994 & 32 \\
\hline $\begin{array}{c}\text { HEU-MET-FAST \& } \\
\text { IEU-MET-FAST (130) }\end{array}$ & Upper Subcritical Limit & 0.984 & 51 \\
\hline$H E U-M E T-T H E R M(14)$ & Lower Tolerance Limit & 0.976 & 53 \\
\hline$H E U-S O L-T H E R M 1-3,7-12(85)$ & Lower Tolerance Limit & $0.994^{\mathrm{A}}$ & 63 \\
\hline $\begin{array}{c}\text { LEU-COMP-THERM \& } \\
\text { LEU-SOL-THERM (71) }\end{array}$ & Lower Tolerance Limit & 0.986 & 69 \\
\hline
\end{tabular}

\footnotetext{
${ }^{A}$ See system description (Section 5.3.2) and bias and uncertainties (Section 5.3.3).
} 


\subsection{PLUTONIUM SYSTEMS}

\subsection{Plutonium Metal}

\subsection{Area of Applicability}

This section presents the MCNP validation analysis for plutonium metal systems. The result from this analysis is a lower tolerance limit (LTL) for the MCNP code system with the ENDF/B-V cross section library. The MCNP user should employ the F-4 flux tally to obtain the average energy to assure that the evaluated system is contained within the applicable neutron spectrum. Key areas of applicability for these experiments include:

1. Fuel:

2. Moderation:

3. Pu-240 Content:

4. Moderating Material:

5. Reflecting Material:

6. Geometry:

7. Neutron Spectrumc:
Plutonium Metal System

$\mathrm{H} / \mathrm{Pu}-239: \sim 0.0$

$1.8-20.1 \mathrm{Wt} \% \mathrm{Pu}-240^{\mathrm{B}}$

None or Slight (Polymer Mock Explosive)

Bare, Thorium, Beryllium, Graphite, Tungsten, Gallium, Polyethylene, Aluminum, Uranium, or Hydrogenous

Single Spheres and Cylindrical Arrays

Fast; $2.5 \mathrm{keV}-1.8 \mathrm{MeV}$

AEG: 4.22-10.04

\subsubsection{System Description}

\subsubsection{Single Unit Plutonium Spheres}

Ten experiments, extracted from the International Handbook of Evaluated Criticality Safety Benchmark Experiments, have been evaluated and documented. These experiments utilized spheres of plutonium metal with different compositions and reflectors. A summary of the experimental parameters is provided in Table 2.

\footnotetext{
${ }^{B}$ See limitations (Sect. 4.1.4).

${ }^{c}$ The neutron-spectrum represents the average energy of the neutrons causing fission.
} 
Table 2. Pu Metal Sphere Experiment Critical Parameters.

\begin{tabular}{|c|c|c|c|c|c|c|c|}
\hline \multirow[t]{2}{*}{ Benchmark Descriptor } & \multirow[t]{2}{*}{ Fuel Alloy } & \multicolumn{4}{|c|}{$\begin{array}{c}\text { Pu Isotopic Composition } \\
\text { (wt \%) }\end{array}$} & \multirow{2}{*}{$\begin{array}{l}\text { Sphere } \\
\text { Radius } \\
(\mathrm{cm})\end{array}$} & \multirow{2}{*}{$\begin{array}{c}\text { Reflector } \\
\& \\
\text { Thickness } \\
\text { (cm) }\end{array}$} \\
\hline & & 239 & 240 & 241 & 242 & & \\
\hline PU-MET-FAST- $001^{5}$ & $\begin{array}{c}98.98 \% \text { o-phase } \\
\mathrm{Pu}, 1.02 \% \mathrm{Ga}\end{array}$ & 95.2 & 4.5 & 0.3 & 0.0 & 6.3849 & None \\
\hline PU-MET-FAST- $002^{5}$ & $\begin{array}{c}98.99 \% \delta \text {-phase } \\
\text { Pu, } 1.01 \% \mathrm{Ga}\end{array}$ & 76.4 & 20.1 & 3.1 & 0.4 & 6.6595 & None \\
\hline PU-MET-FAST- $005^{5}$ & $\begin{array}{c}99.00 \% \delta \text {-phase } \\
\mathrm{Pu}, 1.00 \% \mathrm{Ga}\end{array}$ & 94.77 & 4.92 & 0.31 & 0.0 & 5.0419 & W, 4.699 \\
\hline PU-MET-FAST-006 & $\begin{array}{c}98.90 \% \delta \text {-phase } \\
\mathrm{Pu}, 1.10 \% \mathrm{Ga}\end{array}$ & 93.8 & 4.80 & 0.30 & 0.0 & 4.5332 & $\mathrm{U} ; 19.6088$ \\
\hline PU-MET-FAST-008 ${ }^{5}$ & $\begin{array}{c}98.99 \% \delta \text {-phase } \\
\mathrm{Pu}, 1.01 \% \mathrm{Ga}\end{array}$ & 94.55 & 5.15 & 0.30 & 0.0 & 5.310 & $\mathrm{Th}, 24.57$ \\
\hline PU-MET-FAST- $009^{5}$ & $\begin{array}{c}99.00 \% \delta \text {-phase } \\
\mathrm{Pu}, 1.00 \% \mathrm{Ga}\end{array}$ & 94.8 & 4.90 & 0.30 & 0.0 & 5.5118 & $\mathrm{Al}, 7.9248$ \\
\hline PU-MET-FAST-010 & $\begin{array}{c}99.00 \% 8 \text {-phase } \\
\mathrm{Pu}, 1.00 \% \mathrm{Ga}\end{array}$ & 94.79 & 4.90 & 0.31 & 0.0 & 5.0419 & $\mathrm{U}, 4.699$ \\
\hline PU-MET-FAST-011 ${ }^{5}$ & $\begin{array}{c}100 \% \delta \text {-phase } P u, \\
0 \% \mathrm{Ga}\end{array}$ & 94.48 & 5.20 & 0.30 & 0.02 & 4.1217 & $\mathrm{H}_{2} \mathrm{O}, 25 . \overline{40}$ \\
\hline PU-MET-FAST-022 ${ }^{5}$ & $\begin{array}{c}98.00 \% \delta \text {-phase } \\
\mathrm{Pu}, 1.00 \% \mathrm{Ga}\end{array}$ & 98.2 & 1.8 & 0.00 & 0.0 & $\begin{array}{c}6.67 \\
\text { (Hollow) }\end{array}$ & None \\
\hline PU-MET-FAST-0235 & Varied by layer & 98.2 & 1.8 & 0.00 & 0.0 & Layered & $\begin{array}{l}\text { Graphite, } \\
2.35\end{array}$ \\
\hline
\end{tabular}

\subsubsection{Arrays of Plutonium Metal Cylinders}

Three sets of benchmark experiments have been evaluated. Experimental arrays were constructed from canned plutonium metal cylinders. Alpha phase plutonium with the composition specified in Table 3 was used for these experiments. Specific details on the experiments are provided in the following sections.

Table 3. Plutonium Isotopic Composition, Arrays of Cylinders.

\begin{tabular}{|c|c|c|c|c|}
\hline Benchmark Descriptor & \multicolumn{4}{|c|}{$\begin{array}{c}\text { Isotopic Composition } \\
\text { (Wt \%) }\end{array}$} \\
\hline & 239 & $\mathbf{2 4 0}$ & $\mathbf{2 4 1}$ & $\mathbf{2 4 2}$ \\
\hline $\begin{array}{c}\text { PU-MET-FAST-003 } \\
\text { 004, and 017 }\end{array}$ & 93.56 & 5.97 & 0.46 & 0.01 \\
\hline
\end{tabular}




\subsection{Unmoderated Button Array}

Four experiments involving arrays of plutonium metal cylinders were evaluated. Plutonium cylinders were contained within aluminum cans with steel lids. Square pitched arrays were constructed using single $(3 \mathrm{~kg})$ and double $(6 \mathrm{~kg})$ parts. Spacing between arrays was maintained by use of aluminum support tubes and spacers fastened to an experimental table by means of a support shoe. Benchmark specifications for these experiments did not include an experimental room. A summary of the experimental parameters for these experiments is provided in Table 4.

Table 4. Reported Parameters for PU-MET-FAST-003.

\begin{tabular}{|c|c|c|c|c|}
\hline $\begin{array}{c}\text { Experiment } \\
\text { Descriptor }\end{array}$ & $\begin{array}{c}\text { Array \& Unit } \\
\text { Size }\end{array}$ & $\begin{array}{c}\text { Vertical CTC } \\
\text { Spacing (cm) }\end{array}$ & $\begin{array}{c}\text { Horizontal CTC } \\
\text { Spacing (cm) }\end{array}$ & Reflector \\
\hline 101 & $\begin{array}{c}2 \times 2 \times 2 \\
3 \mathrm{~kg} \mathrm{Cyl.}\end{array}$ & 5.40 & 7.30 & None \\
\hline 102 & $\begin{array}{c}2 \times 2 \times 2 \\
3 \mathrm{~kg} \mathrm{Cyl} .\end{array}$ & 5.74 & 7.64 & Polyethylene \\
\hline 103 & $\begin{array}{c}3 \times 3 \times 3 \\
3 \mathrm{~kg} \mathrm{Cyl} .\end{array}$ & 7.71 & 9.60 & None \\
\hline 105 & $\begin{array}{c}2 \times 2 \times 1 \\
6 \mathrm{~kg} \mathrm{Cyl.}\end{array}$ & $\mathrm{N} / \mathrm{A}$ & 7.59 & None \\
\hline
\end{tabular}

\subsection{Unmoderated Cylinders Array}

Nine experiments involving three-dimensional arrays of plutonium metal cylinders were evaluated. These experiments are similar to the experiments described in section 4.1.2.2.1 with the exceptions noted in the following paragraph.

Square pitched arrays were constructed using single and double parts. Spacing between arrays was maintained by use of aluminum support tubes and spacers fastened to an experimental table by means of a support shoe. A summary of the experimental parameters for these experiments is provided in Table 5.

\footnotetext{
${ }^{D}$ Center-to-center spacing measured from centers of double and single parts.
} 
Table 5. Reported Parameters for PU-MET-FAST-004.

\begin{tabular}{|c|c|c|c|c|}
\hline $\begin{array}{c}\text { Experiment } \\
\text { Descriptor }\end{array}$ & $\begin{array}{c}\text { Array \& Unit } \\
\text { Size }\end{array}$ & $\begin{array}{c}\text { Vertical CTC } \\
\text { Spacing (cm) }\end{array}$ & $\begin{array}{c}\text { Horizontal CTC } \\
\text { Spacing (cm) }\end{array}$ & Reflector \\
\hline 207 & $4 \times 4 \times 4$, bare $3 \mathrm{~kg}$ & $7.86 \pm 0.01$ & $12.51 \pm 0.01$ & None \\
\hline 208 & $4 \times 4 \times 4$, bare $6 \mathrm{~kg}$ & $17.12 \pm 0.02$ & $17.28 \pm 0.01$ & None \\
\hline 209 & $4 \times 4 \times 4$, bare $6 \mathrm{~kg}$ & $32.12 \pm 0.02$ & $13.09 \pm 0.01$ & None \\
\hline 210 & $4 \times 4 \times 4$, bare $6 \mathrm{~kg}$ & $47.12 \pm 0.02$ & $11.93 \pm 0.01$ & None \\
\hline 211 & $4 \times 4 \times 4$, bare $6 \mathrm{~kg}$ & $22.12 \pm 0.02$ & $15.23 \pm 0.01$ & None \\
\hline 212 & $4 \times 4 \times 4$, bare $6 \mathrm{~kg}$ & $13.12 \pm 0.02$ & $20.19 \pm 0.02$ & None \\
\hline 213 & $4 \times 4 \times 1$, bare $6 \mathrm{~kg}$ & $\mathrm{~N} / \mathrm{A}$ & $10.91 \pm 0.02$ & None \\
\hline 214 & $3 \times 3 \times 3$, bare $6 \mathrm{~kg}$ & $13.68 \pm 0.02$ & $14.51 \pm 0.03$ & None \\
\hline 215 & $2 \times 2 \times 2$, bare $6 \mathrm{~kg}$ & $11.98 \pm 0.02$ & $9.76 \pm 0.03$ & None \\
\hline
\end{tabular}

\subsection{Moderated Cylinders Array}

Five experiments involving three-dimensional arrays of moderated plutonium metal cylinders were evaluated. These experiments were conducted using the same support apparatus as the experiments in section 4.1.2.2.1. Moderator jackets and end disks were added to the outside of the support tube and above or below heat sinks, respectively. These disks were made of a mock explosive material. A polymer material consisting primarily of carbon, hydrogen, and oxygen was used for the mock explosive moderator disks. Three sizes of moderator jackets and end disks were used. The dimensions of these moderator pieces are provided in Table 6 .

Table 6. Moderator Dimensions For PU-MET-FAST-017.

\begin{tabular}{|c|c|c|}
\hline Case \# & Thickness $(\mathrm{cm})$ & Jacket Height $(\mathrm{cm})$ \\
\hline 201 & 1.2707 & 13.493 \\
\hline 202 & 2.5487 & 16.049 \\
\hline 203 & 3.8163 & 18.5842 \\
\hline 204 & 1.2707 & 8.3964 \\
\hline 205 & 2.5487 & 10.9524 \\
\hline
\end{tabular}




\subsubsection{Flooded Arrays of Plutonium Metal Cylinders (Phases I \& II)}

Two sets of benchmark experiments have been evaluated. A total of thirty-eight experiments were extracted from the International Handbook of Evaluated Criticality Safety Benchmark Experiments. Experimental arrays constructed from plutonium metal cylinders were flooded with water. Alpha phase plutonium in varying compositions was used for these experiments. Details on the experiments are provided in the following sections.

\subsection{Flooded Array of Cylinders (Phase I)}

Thirteen experiments involving water reflected arrays of plutonium metal cylinders were conducted at the Rocky Flats Critical Mass Laboratory (CML). Plutonium metal cylinders were assembled into a $3 \times 3 \times 3$ array and flooded with water. For each of the thirteen experiments, horizontal and vertical spacings were chosen and water was added until the array was critical. However, three of the measurements remained subcritical on full reflection and are not considered acceptable benchmark experiments. Four of the remaining ten experiments were repeated measurements and were not considered valid. Five out of the remaining six experiments were evaluated and considered valid as benchmark experiments. Plutonium cylinders were contained within aluminum cans with steel lids. Square pitched arrays were constructed using twenty-seven $3-\mathrm{kg}$ plutonium metal parts. Spacing between arrays was maintained by the use of aluminum support tubes and spacers. Specific details on the benchmark specifications for these experiments can be found in Reference 7. A summary of the experimental parameters for these experiments is provided in Table 7 .

Table 7. Reported Parameters for PU-MET-FAST-016 ${ }^{5}$ (CTC Spacing and Critical Water Heights).

\begin{tabular}{|c|c|c|c|c|}
\hline $\begin{array}{c}\text { Benchmark } \\
\text { Case \# }\end{array}$ & $\begin{array}{c}\text { Experiment } \\
\text { Number }\end{array}$ & $\begin{array}{c}\text { Lateral Spacing } \\
\Delta \mathrm{X}=\Delta \mathrm{Y}(\mathrm{cm})\end{array}$ & $\begin{array}{c}\text { Vertical Spacing } \\
\Delta \mathrm{Z}(\mathrm{cm})\end{array}$ & $\begin{array}{c}\text { Water Height } \\
(\mathrm{cm})\end{array}$ \\
\hline 2 & 2 & 12.70 & 12.75 & 58.40 \\
\hline 3 & 3 & 12.90 & 12.75 & 60.60 \\
\hline 4 & $6-9$ & 13.00 & 12.75 & 62.78 \\
\hline 5 & 10 & 13.05 & 12.75 & 65.80 \\
\hline 6 & 13 & 12.80 & 13.10 & 65.60 \\
\hline
\end{tabular}


Table 8 lists the atom densities for the plutonium isotopes.

Table 8. Atom Densities for Plutonium Metal.

\begin{tabular}{|c|c|}
\hline Isotope & Atoms/barn-cm \\
\hline $\mathrm{Pu}-239$ & $4.6054 \times 10^{-2}$ \\
\hline $\mathrm{Pu}-240$ & $2.9264 \times 10^{-3}$ \\
\hline $\mathrm{Pu}-241$ & $9.9882 \times 10^{-5}$ \\
\hline $\mathrm{Pu}-242$ & $4.8613 \times 10^{-6}$ \\
\hline $\mathrm{Am}-241$ & $1.2467 \times 10^{-4}$ \\
\hline
\end{tabular}

\subsection{Flooded Array of Cylinders (Phase II)}

Sixteen experiments were conducted at the Rocky Flats Critical Mass Laboratory (CML) and used for this evaluation. These experiments (PU-MET-FAST-037 ) are similar to the experiments described in section 4.1.2.3.1. The plutonium cans were placed on aluminum trays instead of inside aluminum sleeves. Plutonium cylinders were assembled into $2 \times 2 \times N$ arrays ( $\mathrm{N}$ is the height in number of cylinders; 2, 3, 4, or 5) and flooded with water. The horizontal and vertical spacing varied between the experiments. The arrays were assembled and water was added until the critical water height could be determined. These sixteen experiments are considered valid for use as benchmark experiments. 


\subsubsection{Bias and Uncertainty}

A computational bias is determined by statistically analyzing the (normalized) calculated $\mathrm{k}_{\text {eff }}$ values from the benchmark experiments. In accordance to Reference 4 , a ShapiroWilk test is performed to determine if the data are normally distributed The data was proven to have a normal distribution. The plot of the $\mathrm{k}_{\mathrm{eff}}$ values versus the average energy group is shown in Figure 1.

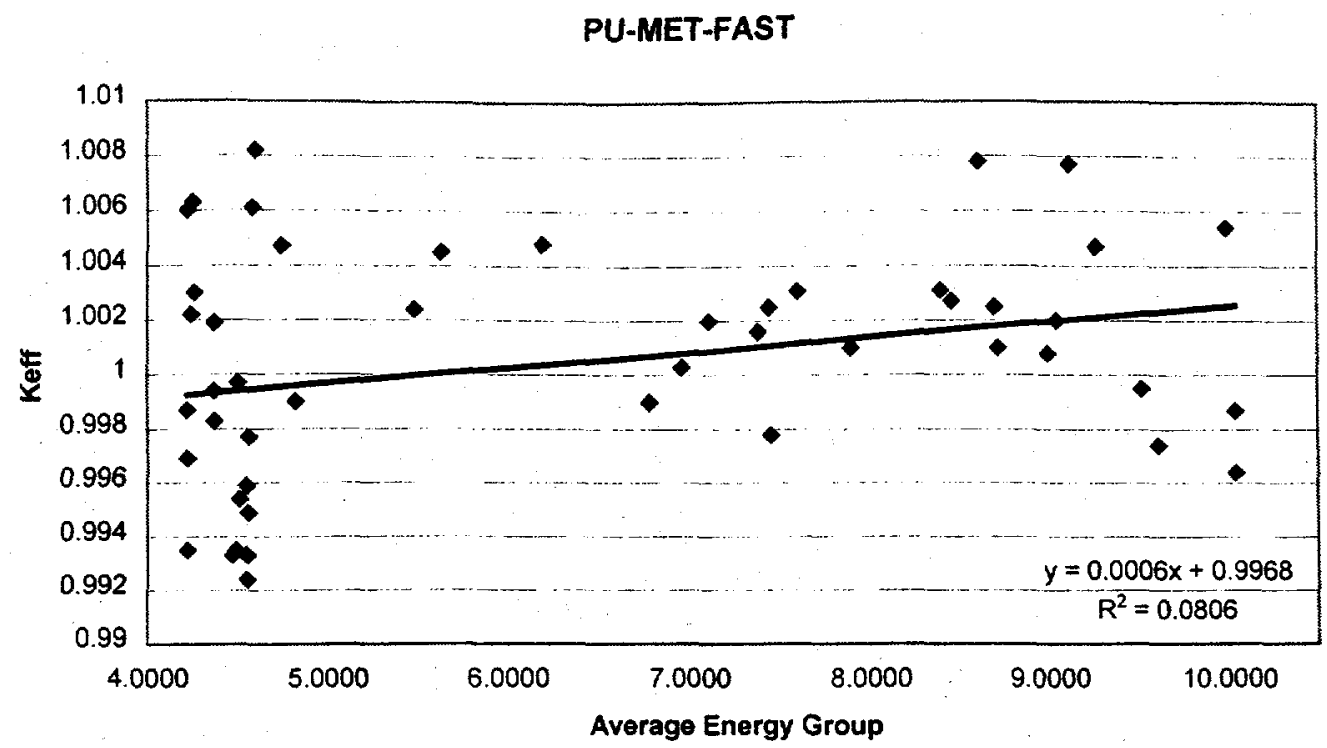

Figure 1. Keff versus Average Energy Group.

The linear correlation coefficient, $\mathrm{R}^{2}$, determines how closely the dependent values fit the least squares regression of the data. A value of one signifies an exact match; compared to zero if there is no correlation. For this data set, there is little correlation between the data and the linear fit. An attempt to fit this data to the curves specified in Reference 4 also failed. Therefore, a lower tolerance limit was calculated using all 49 experimental cases and Equation 1 below.

$$
\mathrm{LTL}=\mathrm{k}_{\mathrm{eff}}-\mathrm{U}^{*} \mathrm{~S}_{\mathrm{p}}
$$

where $\quad k_{\text {eff }}$ is the weighted mean $k_{\text {eff }}$ value

$\mathrm{S}_{\mathrm{p}}$ is the pooled variance, and

$\mathrm{U}$ is the one-sided lower tolerance factor 
Table 9 summarizes the results of the statistical analysis for this data set.

Table 9. Results from Statistical Analysis.

\begin{tabular}{|l|c|}
\hline & $\begin{array}{c}\text { All 49 Experiments } \\
\text { (WEIGHTED DATA) }\end{array}$ \\
\hline One-sided Lower Tolerance Factor (U) & $2.092^{*}$ \\
\hline Sqrt of Pooled Variance $(\mathrm{Sp})$ & $5.279 \mathrm{E}-03$ \\
\hline Variance About the Mean $\left(\mathrm{S}^{2}\right)$ & $2.037 \mathrm{E}-05$ \\
\hline Average Uncertainty $\left(\sigma^{2}\right)$ & $7.503 \mathrm{E}-06$ \\
\hline Average $\mathrm{k}_{\text {eff }}$ & 1.0015 \\
\hline Lower Tolerance Limit & 0.990 \\
\hline
\end{tabular}

\footnotetext{
* This is the tolerance factor for $\mathbf{4 5}$ data points; therefore, it is conservative for this data set.
} 


\subsubsection{Limitations}

The evaluated experiments utilized the following reflector types: aluminum, beryllium, uranium, graphite, gallium, tungsten, polyethylene, water, and thorium. Thus, the results obtained from this analysis are applicable only to plutonium reflected by these reflector types with the average energy of the fissioning neutrons from $2.5 \mathrm{keV}$ to $1.8 \mathrm{MeV}$ using MCNP 4B running on the WSMS DEC Alpha workstation. Many of these reflector types had only a single experimental point, so care should be taken when evaluating systems with those reflectors, due to the scarcity of data. These results are not applicable to thermal systems, or systems containing significant interstitial moderation (i.e., H/Pu-239 ratio $\neq 0$ ).

The data used in this validation covers a broad spectrum of materials with various Pu-240 contents. The $\mathrm{Pu}-240$ content ranged from 1.8-20.1\%. There was one experiment with $\mathrm{Pu}-240$ content of $20.1 \%$ and two experiments with $\mathrm{Pu}-240$ content of $1.8 \%$. The majority of the experiments, however, had Pu-240 content near $5 \%$. Therefore, a subcritical margin as low as 0.02 may be appropriate for those experiments having $\mathrm{Pu}$ 240 content near $5 \%$. The use of this bias with cases having $\mathrm{Pu}-240$ content significantly different from $5 \%$ requires the use of the area of applicability margin (AOA) ${ }^{4}$. 


\subsection{Plutonium Solutions}

\subsubsection{Area of Applicability}

This section presents the MCNP validation analysis for plutonium nitrate solution systems. The result from this analysis is an upper subcritical limit for the MCNP code system with the ENDF/B-V cross section library. The MCNP user should employ the F4 flux tally to obtain the average energy to assure that the evaluated system is contained within the applicable neutron spectrum. Key areas of applicability for these experiments include:

1. Fuel:

2. Moderation:

Plutonium Nitrate $\left(\mathrm{PU}\left(\mathrm{NO}_{3}\right)_{4}\right)$ Solution

3. Pu-240 Content:

$\mathrm{H} / \mathrm{Pu}-239: 300$ to 1200

4. Moderating Material:

$0.54-18.91$ wt $\% \mathrm{Pu}-240^{\mathrm{E}}$

5. Reflecting Material:

Hydrogenous Material

6. Geometry:

Bare or Water Reflected

7. Neutron Spectrum ${ }^{\mathrm{F}}$ :

Single Spheres or Slabs

Thermal; $0.062-0.30 \mathrm{eV}$

\subsection{2 - System Description}

Ninety-six critical experiments involving unreflected and water reflected spheres, slabs, and also cylinders were extracted from the International Handbook Of Evaluated Criticality Benchmark Experiments for this evaluation. The experimental configurations for these experiments are described in the following sections.

\subsubsection{Unreflected Spheres}

\subsection{Unreflected 16 Inch Diameter Spheres}

Five of the experiments utilized a single unreflected 16-inch diameter sphere of plutonium nitrate $\left(\mathrm{Pu}\left(\mathrm{NO}_{3}\right)_{4}\right)$ solution. The isotopic distribution of the plutonium is given in Table 10. The plutonium used in these experiments was $95.83 \mathrm{wt} \% \mathrm{Pu}-239$ and 4.17 wt $\%$ Pu-240.

\footnotetext{
${ }^{E}$ See limitations (Sect. 4.2.4).

F The neutron spectrum represents the average energy of the neutrons causing fission.
} 
Table 10. Pu Isotopic Distribution for PU-SOL-THERM-011 ${ }^{5}$.

\begin{tabular}{|c|c|c|}
\hline Isotope & $\begin{array}{c}\text { Wt \%, 16" } \\
\text { Spheres }\end{array}$ & Wt \%, 18" Spheres \\
\hline${ }^{239} \mathrm{Pu}$ & 95.83 & 95.80 \\
\hline${ }^{2+0} \mathrm{Pu}$ & 4.17 & 4.20 \\
\hline
\end{tabular}

The geometry data are given in Table 11 .

Table 11. Geometry Data for PU-SOL-THERM-011.

\begin{tabular}{|c|c|c|}
\hline Parameter & $\begin{array}{c}\text { 16" } \\
\text { Sphere } \\
\text { Dimension } \\
\text { s, cm }\end{array}$ & $\begin{array}{c}\text { 18" } \\
\text { Sphere } \\
\text { Dimension } \\
\text { s, cm }\end{array}$ \\
\hline Solution Outer Radius & 20.1206 & 22.6974 \\
\hline Sphere Outer Radius & 20.2476 & 22.8244 \\
\hline Cadmium Outer Radius & N/A & 22.8752 \\
\hline
\end{tabular}

A summary of the reported experimental parameters is provided in Table 12 .

Table 12. Reported 16-Inch Sphere Experiment Parameters (Fuel Material Atom Densities (atoms/barn-cm) for PU-SOL-THERM-011, 16" Cases).

\begin{tabular}{|c|c|c|c|c|c|}
\hline Case $\rightarrow$ & $16-1$ & $16-2$ & $16-3$ & $16-4$ & $16-5$ \\
\hline$H$ & $6.4544 \mathrm{E}-02$ & $6.4357 \mathrm{E}-02$ & $6.3652 \mathrm{E}-02$ & $6.2803 \mathrm{E}-02$ & $6.0233 \mathrm{E}-02$ \\
\hline $\mathrm{O}$ & $3.4983 \mathrm{E}-02$ & $3.5017 \mathrm{E}-02$ & $3.5976 \mathrm{E}-02$ & $3.5964 \mathrm{E}-02$ & $3.7178 \mathrm{E}-02$ \\
\hline $\mathrm{N}$ & $1.0140 \mathrm{E}-03$ & $1.0625 \mathrm{E}-03$ & $1.5831 \mathrm{E}-03$ & $1.7482 \mathrm{E}-03$ & $2.7369 \mathrm{E}-03$ \\
\hline $\mathrm{Pu}-239$ & $8.4397 \mathrm{E}-05$ & $8.7439 \mathrm{E}-05$ & $9.2050 \mathrm{E}-05$ & $9.2122 \mathrm{E}-05$ & $1.0484 \mathrm{E}-04$ \\
\hline $\mathrm{Pu}-240$ & $3.6572 \mathrm{E}-06$ & $3.7890 \mathrm{E}-06$ & $3.9888 \mathrm{E}-06$ & $3.9919 \mathrm{E}-06$ & $4.5432 \mathrm{E}-06$ \\
\hline $\mathrm{Fe}$ & $1.1215 \mathrm{E}-06$ & $1.2940 \mathrm{E}-06$ & $1.3371 \mathrm{E}-06$ & $1.9194 \mathrm{E}-06$ & $1.9302 \mathrm{E}-06$ \\
\hline
\end{tabular}




\subsection{Unreflected 18 Inch Diameter Spheres}

Seven of the experiments utilized a single unreflected 18-inch diameter sphere of plutonium nitrate $\left(\mathrm{Pu}\left(\mathrm{NO}_{3}\right)_{4}\right)$ solution. A thin cadmium shell $(0.02$ inches thick) was placed on the outside of the spherical reactor tank. A summary of the reported experimental parameters is provided in Table 13. The plutonium used in these experiments was $95.8 \mathrm{wt} \% \mathrm{Pu}-239$ and $4.2 \mathrm{wt} \% \mathrm{Pu}-240$.

Table 13. Reported 18-Inch Sphere Experiment Parameters (Fuel Material Atom Densities (atoms/barn-cm) for PU-SOL-THERM-011, 18" Cases).

\begin{tabular}{|c|c|c|c|c|c|c|c|}
\hline Case $\rightarrow$ & $18-1$ & $18-2$ & $18-3$ & $18-4$ & $18-5$ & $18-6$ & $18-7$ \\
\hline $\mathrm{H}$ & $6.5147 \mathrm{E}-02$ & $6.4659 \mathrm{E}-02$ & $6.4569 \mathrm{E}-02$ & $6.3220 \mathrm{E}-02$ & $6.3180 \mathrm{E}-02$ & $6.0264 \mathrm{E}-02$ & $6.3701 \mathrm{E}-02$ \\
\hline $\mathrm{O}$ & $3.4534 \mathrm{E}-02$ & $3.4820 \mathrm{E}-02$ & $3.5018 \mathrm{E}-02$ & $3.5333 \mathrm{E}-02$ & $3.6553 \mathrm{E}-02$ & $3.7209 \mathrm{E}-02$ & $3.5021 \mathrm{E}-02$ \\
\hline $\mathrm{N}$ & $7.3930 \mathrm{E}-04$ & $9.4957 \mathrm{E}-04$ & $1.0468 \mathrm{E}-03$ & $1.4414 \mathrm{E}-03$ & $1.9343 \mathrm{E}-03$ & $2.7753 \mathrm{E}-03$ & $1.2199 \mathrm{E}-03$ \\
\hline $\mathrm{Pu}-239$ & $5.3938 \mathrm{E}-05$ & $5.6159 \mathrm{E}-05$ & $5.5748 \mathrm{E}-05$ & $5.7486 \mathrm{E}-05$ & $6.0816 \mathrm{E}-05$ & $6.6343 \mathrm{E}-05$ & $5.7776 \mathrm{E}-05$ \\
\hline $\mathrm{Pu}-240$ & $2.3549 \mathrm{E}-06$ & $2.4518 \mathrm{E}-06$ & $2.4339 \mathrm{E}-06$ & $2.5097 \mathrm{E}-06$ & $2.6552 \mathrm{E}-06$ & $2.8964 \mathrm{E}-06$ & $2.5224 \mathrm{E}-06$ \\
\hline $\mathrm{Fe}$ & $1.2940 \mathrm{E}-06$ & $1.3587 \mathrm{E}-06$ & $1.4557 \mathrm{E}-06$ & $1.3263 \mathrm{E}-06$ & $1.4773 \mathrm{E}-06$ & $1.5204 \mathrm{E}-06$ & $4.1947 \mathrm{E}-07$ \\
\hline
\end{tabular}

\subsection{Unreflected 48-Inch Diameter Sphere}

This validation contains three experiments consisting of bare, type 1100 aluminum spheres filled with highly enriched $(97.386 \% \mathrm{Pu}-239)$ plutonium nitrate solutions. The plutonium concentration in the solution is varied $(9.457$ to $10.020 \mathrm{~g} / 1)$, as is the height of solution in the spherical tank. The $\mathrm{H} / \mathrm{Pu}-239$ ratio varied between 2648.2 and 2802.8 . The isotopic distribution of the plutonium is given in Table 14.

Table 14. Pu Isotopic Distribution for PU-SOL-THERM-0095.

\begin{tabular}{|c|c|}
\hline Isotope & $\begin{array}{c}\text { Weight } \\
\text { Percent }\end{array}$ \\
\hline${ }^{238} \mathrm{Pu}$ & 0.004 \\
\hline${ }^{239} \mathrm{Pu}$ & 97.386 \\
\hline${ }^{240} \mathrm{Pu}$ & 2.521 \\
\hline${ }^{241} \mathrm{Pu}$ & 0.075 \\
\hline${ }^{242} \mathrm{Pu}$ & 0.014 \\
\hline
\end{tabular}


The geometry data are given in Table 15. In addition, the heights of the solution above the midline of the spherical tank are 15.9558 and $45.3705 \mathrm{~cm}$, respectively, for cases 1 and 2 . In case 3 , the tank was completely full.

Table 15. Geometry Data for PU-SOL-THERM-009.

\begin{tabular}{|c|c|}
\hline Parameter & $\begin{array}{c}\text { Dimension } \\
(\mathbf{c m})\end{array}$ \\
\hline Solution Outer Radius & 60.964 \\
\hline Tank Outer Radius & 61.734 \\
\hline
\end{tabular}

The material data for the plutonium solution given in PU-SOL-THERM-009/Table 4 of Reference 5 are used to calculate the weight fractions for the isotopes in the solution, for input into MCNP. Note that two classes of material specifications are provided: one modeling the impurities and one ignoring the impurities. In the validations performed in this document, the impurities are disregarded, since Reference 5 indicates that they have a very small reactivity effect $(\Delta \mathrm{k}=\sim 0.0003)$. This effect is included in the experimental $\mathrm{k}_{\mathrm{eff}}$ 's. The resulting weight fractions are given in Table 16, and are consistent with the atom densities presented in PU-SOL-THERM-009/Table 6 of Reference 5.

Table 16. Fuel Material Weight Fractions for PU-SOL-THERM-009.

\begin{tabular}{|c|c|c|c|c|c|c|c|c|c|}
\hline Case & $\rho(g / c c)$ & ${ }^{238} \mathbf{P u}$ & ${ }^{239} \mathbf{P u}$ & ${ }^{240} \mathbf{P u}$ & ${ }^{241} \mathbf{P u}$ & ${ }^{242} \mathbf{P u}$ & $\mathbf{N}$ & $\mathbf{H}$ & $\mathbf{O}$ \\
\hline $\mathbf{1}$ & 1.055 & $3.7991 \mathrm{E}-07$ & $9.2494 \mathrm{E}-03$ & $2.3944 \mathrm{E}-04$ & $7.1232 \mathrm{E}-06$ & $1.3297 \mathrm{E}-06$ & $1.6830 \mathrm{E}-02$ & $1.0343 \mathrm{E}-01$ & $8.7027 \mathrm{E}-01$ \\
\hline $\mathbf{2}$ & 1.053 & $3.6236 \mathrm{E}-07$ & $8.8221 \mathrm{E}-03$ & $2.2837 \mathrm{E}-04$ & $6.7942 \mathrm{E}-06$ & $1.2682 \mathrm{E}-06$ & $1.6755 \mathrm{E}-02$ & $1.0352 \mathrm{E}-01$ & $8.7071 \mathrm{E}-01$ \\
\hline $\mathbf{3}$ & 1.053 & $3.5924 \mathrm{E}-07$ & $8.7462 \mathrm{E}-03$ & $2.2641 \mathrm{E}-04$ & $6.7358 \mathrm{E}-06$ & $1.2573 \mathrm{E}-06$ & $1.6804 \mathrm{E}-02$ & $1.0351 \mathrm{E}-01$ & $8.7071 \mathrm{E}-01$ \\
\hline
\end{tabular}

\subsubsection{Water Reflected Spheres}

\subsection{Water Reflected 11.5-Inch Diameter Sphere}

This validation contains six experiments consisting of water reflected, type $304 \mathrm{~L}$ stainless steel spheres partially filled with highly enriched $(95.011 \% \mathrm{Pu}-239)$ plutonium nitrate solutions. The plutonium concentration in the solution is varied ( 73.0 to $268.7 \mathrm{~g} / \mathrm{l})$, as is the height of solution in the spherical tank. The $\mathrm{H} / \mathrm{Pu}-239$ ratio varied between 91.2 and 371.3. The isotopic distribution of the plutonium is given in Table 17. 
Table 17. Pu Isotopic Distribution for PU-SOL-THERM-001 ${ }^{5}$.

\begin{tabular}{|c|c|}
\hline Isotope & $\begin{array}{c}\text { Weight } \\
\text { Percent }\end{array}$ \\
\hline${ }^{238} \mathrm{Pu}$ & 0.006 \\
\hline${ }^{239} \mathrm{Pu}$ & 95.011 \\
\hline${ }^{240} \mathrm{Pu}$ & 4.668 \\
\hline${ }^{241} \mathrm{Pu}$ & 0.305 \\
\hline${ }^{242} \mathrm{Pu}$ & 0.009 \\
\hline
\end{tabular}

The geometry data are given in Table 18. In addition, the heights of the solution above the midline of the spherical tank are 12.9807, 13.3995, 12.9091, 13.2170, 13.2170, and $13.0555 \mathrm{~cm}$ for the six cases respectively.

Table 18. Geometry Data for PU-SOL-THERM-001.

\begin{tabular}{|c|c|}
\hline Parameter & $\begin{array}{c}\text { Dimension } \\
\text { (cm) }\end{array}$ \\
\hline Solution Outer Radius & 14.5603 \\
\hline Tank Outer Radius & 14.6848 \\
\hline Reflector Outside Radius & 34.6848 \\
\hline
\end{tabular}

The material data for the plutonium solution given in PU-SOL-THERM-001/Table 2 of Reference 5 are used to create weight fractions for the fuel solution constituents for input into MCNP. The resulting weight fractions are given in Table 19, and are consistent with the atom densities presented in PU-SOL-THERM-001/Table 6 of Reference 5.

Table 19. Fuel Material Weight Fractions for PU-SOL-THERM-001.

\begin{tabular}{|c|c|c|c|c|c|c|c|c|c|}
\hline Case & $\rho(\mathrm{g} / \mathrm{cc})$ & $238 \mathrm{Pu}$ & ${ }^{239} \mathrm{Pu}$ & $240 \mathrm{Pu}$ & $241 \mathrm{Pu}$ & $242 \mathrm{Pu}$ & $\mathbf{N}$ & $\mathbf{H}$ & $\mathbf{0}$ \\
\hline 1 & 1.130 & $3.8761 \mathrm{E}-06$ & $6.1379 \mathrm{E}-02$ & $3.0156 \mathrm{E}-03$ & $1.9704 \mathrm{E}-04$ & $5.8142 \mathrm{E}-06$ & $1.7612 \mathrm{E}-02$ & $9.6101 \mathrm{E}-02$ & $8.2169 \mathrm{E}-01$ \\
\hline 2 & 1.219 & $4.7252 \mathrm{E}-06$ & $7.4824 \mathrm{E}-02$ & $3.6762 \mathrm{E}-03$ & $2.4020 \mathrm{E}-04$ & $7.0878 \mathrm{E}-06$ & $3.7637 \mathrm{E}-02$ & $8.5664 \mathrm{E}-02$ & $7.9793 \mathrm{E}-01$ \\
\hline 3 & 1.270 & $5.6220 \mathrm{E}-06$ & $8.9026 \mathrm{E}-02$ & $4.3740 \mathrm{E}-03$ & $2.8579 \mathrm{E}-04$ & $8.4331 \mathrm{E}-06$ & $4.4005 \mathrm{E}-02$ & $8.1023 \mathrm{E}-02$ & $7.8128 \mathrm{E}-01$ \\
\hline 4 & 1.293 & $6.1253 \mathrm{E}-06$ & $9.6995 \mathrm{E}-02$ & $4.7655 \mathrm{E}-03$ & $3.1137 \mathrm{E}-04$ & $9.1879 \mathrm{E}-06$ & $4.8831 \mathrm{E}-02$ & $7.7878 \mathrm{E}-02$ & $7.7122 \mathrm{E}-01$ \\
\hline 5 & 1.307 & $6.4269 \mathrm{E}-06$ & $1.0177 \mathrm{E}-01$ & $5.0002 \mathrm{E}-03$ & $3.2670 \mathrm{E}-04$ & $9.6404 \mathrm{E}-06$ & $4.8671 \mathrm{E}-02$ & $7.7309 \mathrm{E}-02$ & $7.6692 \mathrm{E}-01$ \\
\hline 6 & 1.484 & $1.0864 \mathrm{E}-05$ & $1.7203 \mathrm{E}-01$ & $8.4521 \mathrm{E}-03$ & $5.5225 \mathrm{E}-04$ & $1.6296 \mathrm{E}-05$ & $5.2806 \mathrm{E}-02$ & $6.6142 \mathrm{E}-02$ & $6.9999 \mathrm{E}-01$ \\
\hline
\end{tabular}




\subsection{Water Reflected 11.5-Inch Diameter Spheres Partly Filled}

This validation contains 11 experiments consisting of water reflected, type 304L stainless steel spheres partially filled with plutonium nitrate solutions with $95.011 \% \mathrm{Pu}-239$. As described in Reference 5, however, only eight of these are considered acceptable for validation purposes (cases 1, 4, and 11 are eliminated). The plutonium concentration in the solution is varied $(93.5$ to $232.0 \mathrm{~g} / 1)$, as is the height of solution in the spherical tank. The $\mathrm{H} / \mathrm{Pu}-239$ ratio varied between 109.6 and 285.0. The isotopic distribution of the plutonium is given in Table 20.

Table 20. Pu Isotopic Distribution for PU-SOL-THERM-0075.

\begin{tabular}{|c|c|}
\hline Isotope & $\begin{array}{c}\text { Weight } \\
\text { Percent }\end{array}$ \\
\hline${ }^{238} \mathrm{Pu}$ & 0.006 \\
\hline${ }^{239} \mathrm{Pu}$ & 95.011 \\
\hline${ }^{240} \mathrm{Pu}$ & 4.668 \\
\hline${ }^{241} \mathrm{Pu}$ & 0.305 \\
\hline${ }^{242} \mathrm{Pu}$ & 0.009 \\
\hline
\end{tabular}

The geometry data are given in Table 21 . In addition, the heights of the solution above the midline of the spherical tank are $10.8373,10.8373,10.9741,10.6720,10.9741$, $10.9051,10.4503$, and $10.8373 \mathrm{~cm}$ for the eight cases respectively.

Table 21. Geometry Data for PU-SOL-THERM-007.

\begin{tabular}{|c|c|}
\hline Parameter & $\begin{array}{c}\text { Dimension } \\
\text { (cm) }\end{array}$ \\
\hline Solution Outer Radius & 14.5603 \\
\hline Tank Outer Radius & 14.6848 \\
\hline Reflector Outside Radius & 34.6848 \\
\hline
\end{tabular}

The material data for the fuel solution given in PU-SOL-THERM-007/Table 2 of Reference 5 are used to calculate the weight fractions for the isotopes in the fissile solution for input into MCNP. The resulting weight fractions are given in Table 22, and are consistent with the atom densities presented in PU-SOL-THERM-007/Table 5 of Reference 5. 
Table 22. Fuel Material Weight Fractions for PU-SOL-THERM-007.

\begin{tabular}{|c|c|c|c|c|c|c|c|c|c|}
\hline Case & $\rho(\mathrm{g} / \mathrm{cc})$ & $238 \mathrm{Pu}$ & $239 \mathrm{Pu}$ & $240 \mathrm{Pu}$ & $24 \mathrm{Pu}$ & $242 \mathrm{Pu}$ & $\mathrm{N}$ & $\mathrm{H}$ & $\mathbf{O}$ \\
\hline 2 & 1.409 & $9.8793 \mathrm{E}-06$ & $1.5644 \mathrm{E}-01$ & $7.6861 \mathrm{E}-03$ & $5.0220 \mathrm{E}-04$ & $1.4819 \mathrm{E}-05$ & $4.3448 \mathrm{E}-02$ & $7.2261 \mathrm{E}-02$ & $7.1964 \mathrm{E}-01$ \\
\hline 3 & 1.386 & $9.5671 \mathrm{E}-06$ & $1.5150 \mathrm{E}-01$ & $7.4432 \mathrm{E}-03$ & $4.8633 \mathrm{E}-04$ & $1.4351 \mathrm{E}-05$ & $4.3729 \mathrm{E}-02$ & $7.2800 \mathrm{E}-02$ & $7.2402 \mathrm{E}-01$ \\
\hline 5 & 1.180 & $5.0949 \mathrm{E}-06$ & $8.0679 \mathrm{E}-02$ & $3.9638 \mathrm{E}-03$ & $2.5899 \mathrm{E}-04$ & $7.6424 \mathrm{E}-06$ & $2.3451 \mathrm{E}-02$ & $9.1005 \mathrm{E}-02$ & $8.0063 \mathrm{E}-01$ \\
\hline 6 & 1.180 & $5.1610 \mathrm{E}-06$ & $8.1726 \mathrm{E}-02$ & $4.0153 \mathrm{E}-03$ & $2.6235 \mathrm{E}-04$ & $7.7415 \mathrm{E}-06$ & $2.4791 \mathrm{E}-02$ & $9.0286 \mathrm{E}-02$ & $7.9891 \mathrm{E}-01$ \\
\hline 7 & 1.179 & $5.0941 \mathrm{E}-06$ & $8.0667 \mathrm{E}-02$ & $3.9632 \mathrm{E}-03$ & $2.5895 \mathrm{E}-04$ & $7.6412 \mathrm{E}-06$ & $2.4889 \mathrm{E}-02$ & $9.0385 \mathrm{E}-02$ & $7.9983 \mathrm{E}-01$ \\
\hline 8 & 1.179 & $5.1705 \mathrm{E}-06$ & $8.1875 \mathrm{E}-02$ & $4.0226 \mathrm{E}-03$ & $2.6283 \mathrm{E}-04$ & $7.7557 \mathrm{E}-06$ & $2.7207 \mathrm{E}-02$ & $8.9224 \mathrm{E}-02$ & $7.9740 \mathrm{E}-01$ \\
\hline 9 & 1.184 & $5.1486 \mathrm{E}-06$ & $8.1530 \mathrm{E}-02$ & $4.0056 \mathrm{E}-03$ & $2.6172 \mathrm{E}-04$ & $7.7230 \mathrm{E}-06$ & $2.7207 \mathrm{E}-02$ & $8.9270 \mathrm{E}-02$ & $7.9772 \mathrm{E}-01$ \\
\hline 10 & 1.165 & $4.8155 \mathrm{E}-06$ & $7.6253 \mathrm{E}-02$ & $3.7464 \mathrm{E}-03$ & $2.4479 \mathrm{E}-04$ & $7.2232 \mathrm{E}-06$ & $2.3365 \mathrm{E}-02$ & $9.1633 \mathrm{E}-02$ & $8.0475 \mathrm{E}-01$ \\
\hline
\end{tabular}

\subsection{Water Reflected 12-Inch Diameter Spheres}

Seven experiments consisting of water reflected, type 347 stainless steel spheres filled with plutonium nitrate solutions $(96.88 \mathrm{wt} \% \mathrm{Pu}-239)$ were evaluated. The plutonium concentration in the solution is varied from 49.84 to $77.09 \mathrm{~g} / 1$. The $\mathrm{H} / \mathrm{Pu}-239$ ratio varied between 309 and 524. The isotopic distribution of the plutonium is given in Table 23.

Table 23. Pu Isotopic Distribution for PU-SOL-THERM-0025

\begin{tabular}{|c|c|}
\hline Isotope & Wt \% \\
\hline & 96.88 \\
\hline${ }^{239} \mathrm{Pu}$ & 3.12 \\
\hline
\end{tabular}

The geometry data are given in Table 24.

Table 24. Geometry Data for PU-SOL-THERM-002.

\begin{tabular}{|c|c|}
\hline Parameter & $\begin{array}{c}\text { Dimension } \\
\text { (cm) }\end{array}$ \\
\hline Solution Outer Radius & 15.3399 \\
\hline Sphere Outer Radius & 15.4669 \\
\hline Reflector Outside Radius & 45.4669 \\
\hline
\end{tabular}


The material data for the fuel solutions given in PU-SOL-THERM-002/Table 3 of Reference 5 was used to calculate atom density values for the fuel solution constituents for input into MCNP. The calculated values were identical to those presented in PUSOL-THERM-002/Table 5 of Reference 5 and are reproduced below as Table 25.

Table 25. Fuel Material Atom Densities (atoms/barn-cm) for PU-SOL-THERM-002.

\begin{tabular}{|c|c|c|c|c|c|c|}
\hline Case & $\mathrm{Pu}-239$ & $\mathrm{Pu}-240$ & $\mathrm{~N}$ & $\mathrm{H}$ & $\mathrm{O}$ & $\mathrm{Fe}$ \\
\hline $\mathbf{1}$ & $1.2164 \mathrm{E}-04$ & $3.9010 \mathrm{E}-06$ & $1.3452 \mathrm{E}-03$ & $6.3772 \mathrm{E}-02$ & $3.5500 \mathrm{E}-02$ & $2.0380 \mathrm{E}-06$ \\
\hline $\mathbf{2}$ & $1.2549 \mathrm{E}-04$ & $4.0246 \mathrm{E}-06$ & $1.5831 \mathrm{E}-03$ & $6.3356 \mathrm{E}-02$ & $3.5895 \mathrm{E}-02$ & $2.9330 \mathrm{E}-06$ \\
\hline $\mathbf{3}$ & $1.3689 \mathrm{E}-04$ & $4.3902 \mathrm{E}-06$ & $2.0104 \mathrm{E}-03$ & $6.1779 \mathrm{E}-02$ & $3.6198 \mathrm{E}-02$ & $2.6419 \mathrm{E}-06$ \\
\hline $\mathbf{4}$ & $1.4555 \mathrm{E}-04$ & $4.6680 \mathrm{E}-06$ & $2.3018 \mathrm{E}-03$ & $6.1211 \mathrm{E}-02$ & $3.6660 \mathrm{E}-02$ & $2.0704 \mathrm{E}-06$ \\
\hline $\mathbf{5}$ & $1.5456 \mathrm{E}-04$ & $4.9568 \mathrm{E}-06$ & $2.6223 \mathrm{E}-03$ & $6.0707 \mathrm{E}-02$ & $3.7228 \mathrm{E}-02$ & $2.1243 \mathrm{E}-06$ \\
\hline 6 & $1.7111 \mathrm{E}-04$ & $5.4875 \mathrm{E}-06$ & $3.1274 \mathrm{E}-03$ & $5.8902 \mathrm{E}-02$ & $3.7623 \mathrm{E}-02$ & $2.3507 \mathrm{E}-06$ \\
\hline 7 & $1.8814 \mathrm{E}-04$ & $6.0338 \mathrm{E}-06$ & $3.4867 \mathrm{E}-03$ & $5.8109 \mathrm{E}-02$ & $3.8160 \mathrm{E}-02$ & $2.5556 \mathrm{E}-06$ \\
\hline
\end{tabular}

Also included in the MCNP models are water for the reflector and type 347 stainless steel for the sphere material. Water is modeled as a combination of hydrogen and oxygen with atom fractions of 2 and 1 , respectively, and a density of $0.99651 \mathrm{~g} / \mathrm{cc}$. The material composition of type 347 stainless steel is taken from Reference 5 and is reproduced as Table 26. The density is assumed to be $7.92 \mathrm{~g} / \mathrm{cc}$.

Table 26. Type 347 Stainless Steel Weight Fractions.

\begin{tabular}{|c|c|}
\hline Element & $\begin{array}{c}\text { Weight } \\
\text { Fraction }\end{array}$ \\
\hline $\mathrm{Fe}$ & 0.685 \\
\hline $\mathrm{Cr}$ & 0.180 \\
\hline $\mathrm{Ni}$ & 0.105 \\
\hline $\mathrm{Mn}$ & 0.020 \\
\hline $\mathrm{Si}$ & 0.010 \\
\hline
\end{tabular}

\subsection{Water Reflected 13-Inch Diameter Spheres}

This validation contains eight experiments consisting of water reflected, type 347 stainless steel or type 2 S aluminum spheres filled with highly enriched ( 96.88 to $98.24 \%$ $\mathrm{Pu}$-239) plutonium nitrate solutions. The plutonium concentration in the solution is varied ( 33.32 to $44.09 \mathrm{~g} / \mathrm{l}$ ), with the tanks completely full. The H/Pu-239 ratio varied between 562.8 and 788.0 . The isotopic distributions of the plutonium are given in Table 27. 
Table 27. Pu Isotopic Distribution for PU-SOL-THERM-0035.

\begin{tabular}{|c|c|c|}
\hline Isotope & $\begin{array}{c}\text { Weight } \\
\text { Percent } \\
\text { (Cases 1-2) }\end{array}$ & $\begin{array}{c}\text { Weight } \\
\text { Percent } \\
\text { (Cases 3-8) }\end{array}$ \\
\hline${ }^{239} \mathrm{Pu}$ & 98.24 & 96.88 \\
\hline${ }^{240} \mathrm{Pu}$ & 1.76 & 3.12 \\
\hline
\end{tabular}

The geometry data are given in Table 28. The steel tank is used in cases 1 through 6 , while the aluminum tank is used in cases 7 and 8 .

Table 28. Geometry Data for PU-SOL-THERM-003.

\begin{tabular}{|c|c|c|}
\hline Parameter & $\begin{array}{c}\text { Steel Tank } \\
\text { Dimension } \\
(\mathbf{c m})\end{array}$ & $\begin{array}{c}\text { Aluminum } \\
\text { Tank } \\
\text { Dimension } \\
\text { (cm) }\end{array}$ \\
\hline Solution Outer Radius & 16.5156 & 16.2487 \\
\hline Tank Outer Radius & 16.6426 & 16.3777 \\
\hline Reflector Outside Radius & 46.6426 & 46.3777 \\
\hline
\end{tabular}

The material data for the plutonium solution given in PU-SOL-THERM-003/Table 3 of Reference 5 are used to calculate the weight fractions for the isotopes in the solution, for input into MCNP. The resulting weight fractions are given in Table 29, and are consistent with the atom densities presented in PU-SOL-THERM-003/Table 5 of Reference 5.

Table 29. Fuel Material Weight Fractions for PU-SOL-THERM-003.

\begin{tabular}{|c|c|c|c|c|c|c|c|}
\hline Case & $\rho(\mathbf{g} / \mathrm{cc})$ & ${ }^{239} \mathrm{Pu}$ & $240 \mathrm{Pu}$ & $\mathbf{N}$ & H & Fe & \\
\hline 1 & 1.0853 & $3.0161 \mathrm{E}-02$ & $5.4034 \mathrm{E}-04$ & $1.8046 \mathrm{E}-02$ & $1.0020 \mathrm{E}-01$ & $8.5094 \mathrm{E}-01$ & $1.1425 \mathrm{E}-04$ \\
\hline 2 & 1.1009 & $3.0626 \mathrm{E}-02$ & $5.4867 \mathrm{E}-04$ & $2.3905 \mathrm{E}-02$ & $9.7614 \mathrm{E}-02$ & $8.4720 \mathrm{E}-01$ & $1.0628 \mathrm{E}-04$ \\
\hline 3 & 1.1107 & $3.2648 \mathrm{E}-02$ & $1.0514 \mathrm{E}-03$ & $2.6440 \mathrm{E}-02$ & $9.6201 \mathrm{E}-02$ & $8.4356 \mathrm{E}-01$ & $9.2734 \mathrm{E}-05$ \\
\hline 4 & 1.1279 & $3.2743 \mathrm{E}-02$ & $1.0545 \mathrm{E}-03$ & $3.1244 \mathrm{E}-02$ & $9.4113 \mathrm{E}-02$ & $8.4072 \mathrm{E}-01$ & $1.2501 \mathrm{E}-04$ \\
\hline 5 & 1.1548 & $3.4103 \mathrm{E}-02$ & $1.0983 \mathrm{E}-03$ & $4.0101 \mathrm{E}-02$ & $9.0103 \mathrm{E}-02$ & $8.3438 \mathrm{E}-01$ & $2.2255 \mathrm{E}-04$ \\
\hline 6 & 1.1908 & $3.5870 \mathrm{E}-02$ & $1.1552 \mathrm{E}-03$ & $5.1125 \mathrm{E}-02$ & $8.5116 \mathrm{E}-02$ & $8.2651 \mathrm{E}-01$ & $2.2338 \mathrm{E}-04$ \\
\hline 7 & 1.0910 & $3.1950 \mathrm{E}-02$ & $1.0289 \mathrm{E}-03$ & $1.9277 \mathrm{E}-02$ & $9.9382 \mathrm{E}-02$ & $8.4826 \mathrm{E}-01$ & $1.0449 \mathrm{E}-04$ \\
\hline 8 & 1.1106 & $3.2110 \mathrm{E}-02$ & $1.0341 \mathrm{E}-03$ & $2.5425 \mathrm{E}-02$ & $9.6707 \mathrm{E}-02$ & $8.4461 \mathrm{E}-01$ & $1.1525 \mathrm{E}-04$ \\
\hline
\end{tabular}




\subsection{Water Reflected 14-Inch Diameter Spheres}

This validation contains 13 experiments consisting of water reflected, type 347 stainless steel spheres filled with plutonium nitrate solutions (96.57 to $99.46 \% \mathrm{Pu}-239$ ). The plutonium concentration in the solution is varied from 26.27 to $39.38 \mathrm{~g} / \mathrm{l}$. The H/Pu-239 ratio is varied between 592 and 987 . The isotopic distributions of the plutonium are given in Table 30.

Table 30. Pu Isotopic Distribution for PU-SOL-THERM-004 ${ }^{5}$.

\begin{tabular}{|c|c|c|c|c|}
\hline Isotope & $\begin{array}{c}\text { Wt \% } \\
(\text { Cases 1-4) }\end{array}$ & $\begin{array}{c}\text { Wt \% } \\
\text { (Case 5) }\end{array}$ & $\begin{array}{c}\text { Wt \% } \\
\text { (Cases 6-12) }\end{array}$ & $\begin{array}{c}\text { Wt \% } \\
\text { (Case 13) }\end{array}$ \\
\hline${ }^{239} \mathrm{Pu}$ & 99.46 & 98.24 & 96.88 & 96.57 \\
\hline${ }^{240} \mathrm{Pu}$ & 0.54 & 1.76 & 3.12 & 3.43 \\
\hline
\end{tabular}

The geometry data are given in Table 31 .

Table 31. Geometry Data for PU-SOL-THERM-004.

\begin{tabular}{|c|c|}
\hline Parameter & $\begin{array}{c}\text { Dimension } \\
\text { (cm) }\end{array}$ \\
\hline Solution Outer Radius & 17.7865 \\
\hline Sphere Outer Radius & 17.9135 \\
\hline Reflector Outside Radius & 47.9135 \\
\hline
\end{tabular}

The material data for the fuel solution given in PU-SOL-THERM-004/Table 3 of Reference 5 are used to calculate atom density values for the fuel solution constituents for input into MCNP. The calculated values were identical to those presented in PU-SOLTHERM-004/Table 5 of Reference 5 and are reproduced below as Table 32. 
Table 32. Fuel Material Atom Densities (atoms/barn-cm) for PU-SOL-THERM-004.

\begin{tabular}{|c|c|c|c|c|c|c|}
\hline Case & Pu-239 & Pu-240 & $\mathrm{N}$ & $\mathrm{H}$ & $\mathrm{O}$ & Fe \\
\hline 1 & & & & & & \\
\hline 2 & $6.5821 \mathrm{E}-05$ & $3.5587 \mathrm{E}-07$ & $7.5562 \mathrm{E}-04$ & $6.4964 \mathrm{E}-02$ & $3.4503 \mathrm{E}-02$ & $1.5636 \mathrm{E}-06$ \\
\hline 3 & $6.8151 \mathrm{E}-05$ & $3.6847 \mathrm{E}-07$ & $1.3354 \mathrm{E}-03$ & $6.3697 \mathrm{E}-02$ & $3.5324 \mathrm{E}-02$ & $1.6822 \mathrm{E}-06$ \\
\hline 4 & $7.0381 \mathrm{E}-05$ & $3.8053 \mathrm{E}-07$ & $1.8211 \mathrm{E}-03$ & $6.2562 \mathrm{E}-02$ & $3.5975 \mathrm{E}-02$ & $1.7684 \mathrm{E}-06$ \\
\hline 5 & $6.8256 \mathrm{E}-05$ & $1.2177 \mathrm{E}-06$ & $1.0635 \mathrm{E}-03$ & $6.4299 \mathrm{E}-02$ & $3.4947 \mathrm{E}-02$ & $1.0136 \mathrm{E}-06$ \\
\hline 6 & $6.9800 \mathrm{E}-05$ & $2.2385 \mathrm{E}-06$ & $8.4885 \mathrm{E}-04$ & $6.4732 \mathrm{E}-02$ & $3.4632 \mathrm{E}-02$ & $1.1862 \mathrm{E}-06$ \\
\hline 7 & $7.2167 \mathrm{E}-05$ & $2.3144 \mathrm{E}-06$ & $1.0635 \mathrm{E}-03$ & $6.4353 \mathrm{E}-02$ & $3.4984 \mathrm{E}-02$ & $1.3803 \mathrm{E}-06$ \\
\hline 8 & $7.3095 \mathrm{E}-05$ & $2.3442 \mathrm{E}-06$ & $1.3889 \mathrm{E}-03$ & $6.3518 \mathrm{E}-02$ & $3.5382 \mathrm{E}-02$ & $1.2185 \mathrm{E}-06$ \\
\hline 9 & $7.7122 \mathrm{E}-05$ & $2.4733 \mathrm{E}-06$ & $2.0202 \mathrm{E}-03$ & $6.2101 \mathrm{E}-02$ & $3.6260 \mathrm{E}-02$ & $1.2940 \mathrm{E}-06$ \\
\hline 10 & $8.6298 \mathrm{E}-05$ & $2.7676 \mathrm{E}-06$ & $3.0060 \mathrm{E}-03$ & $5.9494 \mathrm{E}-02$ & $3.7440 \mathrm{E}-02$ & $1.5636 \mathrm{E}-06$ \\
\hline 11 & $9.6109 \mathrm{E}-05$ & $3.0823 \mathrm{E}-06$ & $3.9626 \mathrm{E}-03$ & $5.6870 \mathrm{E}-02$ & $3.8540 \mathrm{E}-02$ & $1.5851 \mathrm{E}-06$ \\
\hline 12 & $7.1850 \mathrm{E}-05$ & $2.3043 \mathrm{E}-06$ & $1.1169 \mathrm{E}-03$ & $6.4144 \mathrm{E}-02$ & $3.5013 \mathrm{E}-02$ & $1.2185 \mathrm{E}-06$ \\
\hline 13 & $7.1207 \mathrm{E}-05$ & $2.5186 \mathrm{E}-06$ & $1.0810 \mathrm{E}-03$ & $6.4304 \mathrm{E}-02$ & $3.5002 \mathrm{E}-02$ & $1.5096 \mathrm{E}-06$ \\
\hline
\end{tabular}

Also included in the MCNP models are water for the reflector, and type 347 stainless steel for the sphere material. Water is modeled as a combination of hydrogen and oxygen with atom fractions of 2 and 1 , respectively, and a density of $0.99651 \mathrm{~g} / \mathrm{cc}$. The material composition of type 347 stainless steel is taken from Reference 3. The density is assumed to be $7.92 \mathrm{~g} / \mathrm{cc}$.

\subsection{Water Reflected 14-Inch Diameter Spheres with 4.05\% and 4.40\% $240 \mathrm{Pu}$}

This validation contains nine experiments consisting of water reflected, type 347 stainless steel spheres filled with highly enriched (95.6 to $95.95 \% \mathrm{Pu}-239)$ plutonium nitrate solutions. The plutonium concentration in the solution is varied $(29.65$ to $40.91 \mathrm{~g} / \mathrm{l})$, with the tanks completely full. The $\mathrm{H} / \mathrm{Pu}-239$ ratio varied between 580.6 and 902.8 . The isotopic distributions of the plutonium are given in Table 33.

Table 33. Pu Isotopic Distribution for PU-SOL-THERM-0055.

\begin{tabular}{|c|c|c|}
\hline Isotope & $\begin{array}{c}\text { Weight } \\
\text { Percent } \\
\text { (Cases 1-7) }\end{array}$ & $\begin{array}{c}\text { Weight } \\
\text { Percent } \\
\text { (Cases 8-9) }\end{array}$ \\
\hline${ }^{239} \mathrm{Pu}$ & 95.95 & 95.60 \\
\hline${ }^{240} \mathrm{Pu}$ & 4.05 & 4.40 \\
\hline
\end{tabular}


The geometry data is given in Table 34 .

Table 34. Geometry Data for PU-SOL-THERM-005.

\begin{tabular}{|c|c|}
\hline Parameter & $\begin{array}{c}\text { Dimension } \\
\text { (cm) }\end{array}$ \\
\hline Solution Outer Radius & 17.7865 \\
\hline Tank Outer Radius & 17.9135 \\
\hline Reflector Outside Radius & 47.9135 \\
\hline
\end{tabular}

The material data for the plutonium solution given in PU-SOL-THERM-005/Table 3 of Reference 5 are used to calculate the weight fractions for the isotopes in the solution, for input into MCNP. The resulting weight fractions are given in Table 35, and are consistent with the atom densities presented in PU-SOL-THERM-005/Table 5 of Reference 5 .

Table 35. Fuel Material Weight Fractions for PU-SOL-THERM-005.

\begin{tabular}{|c|c|c|c|c|c|c|c|}
\hline Case & $\rho(\mathrm{g} / \mathrm{cc})$ & ${ }^{239} \mathrm{Pu}$ & ${ }^{240} \mathrm{Pu}$ & $\mathrm{N}$ & $\mathbf{H}$ & $\mathbf{O}$ & $\mathrm{Fe}$ \\
\hline 1 & 1.0777 & $2.6398 \mathrm{E}-02$ & $1.1142 \mathrm{E}-03$ & $1.8339 \mathrm{E}-02$ & $1.0048 \mathrm{E}-01$ & $8.5355 \mathrm{E}-01$ & $1.1877 \mathrm{E}-04$ \\
\hline 2 & 1.0967 & $2.6719 \mathrm{E}-02$ & $1.1278 \mathrm{E}-03$ & $2.4573 \mathrm{E}-02$ & $9.7752 \mathrm{E}-02$ & $8.4976 \mathrm{E}-01$ & $7.2034 \mathrm{E}-05$ \\
\hline 3 & 1.1117 & $2.7127 \mathrm{E}-02$ & $1.1450 \mathrm{E}-03$ & $2.9830 \mathrm{E}-02$ & $9.5430 \mathrm{E}-02$ & $8.4639 \mathrm{E}-01$ & $7.7359 \mathrm{E}-05$ \\
\hline 4 & 1.1496 & $2.7994 \mathrm{E}-02$ & $1.1816 \mathrm{E}-03$ & $4.1403 \mathrm{E}-02$ & $9.0321 \mathrm{E}-02$ & $8.3901 \mathrm{E}-01$ & $8.4377 \mathrm{E}-05$ \\
\hline 5 & 1.1826 & $2.9241 \mathrm{E}-02$ & $1.2342 \mathrm{E}-03$ & $5.2033 \mathrm{E}-02$ & $8.5569 \mathrm{E}-02$ & $8.3183 \mathrm{E}-01$ & $8.7942 \mathrm{E}-05$ \\
\hline 6 & 1.2172 & $3.0341 \mathrm{E}-02$ & $1.2807 \mathrm{E}-03$ & $6.2209 \mathrm{E}-02$ & $8.1032 \mathrm{E}-02$ & $8.2503 \mathrm{E}-01$ & $1.0352 \mathrm{E}-04$ \\
\hline 7 & 1.2405 & $3.1643 \mathrm{E}-02$ & $1.3356 \mathrm{E}-03$ & $7.0091 \mathrm{E}-02$ & $7.7460 \mathrm{E}-02$ & $8.1937 \mathrm{E}-01$ & $1.0157 \mathrm{E}-04$ \\
\hline 8 & 1.1019 & $2.6531 \mathrm{E}-02$ & $1.2211 \mathrm{E}-03$ & $2.5933 \mathrm{E}-02$ & $9.7174 \mathrm{E}-02$ & $8.4904 \mathrm{E}-01$ & $9.8013 \mathrm{E}-05$ \\
\hline 9 & 1.1205 & $2.7174 \mathrm{E}-02$ & $1.2507 \mathrm{E}-03$ & $3.1853 \mathrm{E}-02$ & $9.4536 \mathrm{E}-02$ & $8.4510 \mathrm{E}-01$ & $9.1031 \mathrm{E}-05$ \\
\hline
\end{tabular}

\subsection{Water Reflected 15-Inch Diameter Spheres}

This validation contains three experiments consisting of water reflected, type 347 stainless steel spheres filled with plutonium nitrate solutions $(96.88 \% \mathrm{Pu}-239)$. The plutonium concentration in the solution is varied from 24.80 to $26.97 \mathrm{~g} / \mathrm{l}$. The $\mathrm{H} / \mathrm{Pu}-239$ ratio varied between 940 and 1061 . The isotopic distributions of the plutonium are given in Table 36.

Table 36. Pu Isotopic Distribution for PU-SOL-THERM-0065.

\begin{tabular}{|l|l|}
\hline Isotope & Wt \% \\
\hline
\end{tabular}




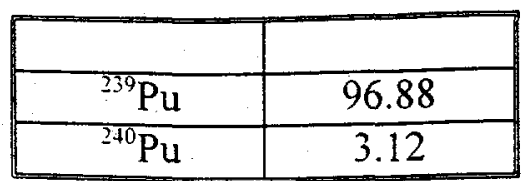

The geometry data are given in Table 37.

Table 37. Geometry Data for PU-SOL-THERM-006.

\begin{tabular}{|c|c|}
\hline Parameter & $\begin{array}{c}\text { Dimension } \\
(\mathrm{cm})\end{array}$ \\
\hline Solution Outer Radius & 19.0416 \\
\hline Sphere Outer Radius & 19.1686 \\
\hline Reflector Outside Radius & 49.1686 \\
\hline
\end{tabular}

The material data for the fuel solution given in PU-SOL-THERM-006/Table 3 of Reference 5 are used to calculate atom density values for the fuel solution constituents for input into MCNP. The calculated values were identical to those presented in PU-SOLTHERM-006/Table 5 of Reference 5 and are reproduced below as Table 38 .

Table 38. Fuel Material Atom Densities (atoms/barn-cm) for PU-SOL-THERM-006.

\begin{tabular}{|c|c|c|c|c|c|c|}
\hline Case & Pu-239 & Pu-240 & N & H & O & Fe \\
\hline 1 & $6.0526 \mathrm{E}-05$ & $1.9411 \mathrm{E}-06$ & $1.1266 \mathrm{E}-03$ & $6.4225 \mathrm{E}-02$ & $3.5054 \mathrm{E}-02$ & $9.4892 \mathrm{E}-07$ \\
\hline 2 & $6.2381 \mathrm{E}-05$ & $2.0006 \mathrm{E}-06$ & $1.4277 \mathrm{E}-03$ & $6.3492 \mathrm{E}-02$ & $3.5444 \mathrm{E}-02$ & $1.0136 \mathrm{E}-06$ \\
\hline 3 & $6.5822 \mathrm{E}-05$ & $2.1109 \mathrm{E}-06$ & $2.0590 \mathrm{E}-03$ & $6.1880 \mathrm{E}-02$ & $3.6223 \mathrm{E}-02$ & $1.0352 \mathrm{E}-06$ \\
\hline
\end{tabular}

Also included in the MCNP models are water for the reflector and type 347 stainless steel for the tank material. Water is modeled as a combination of hydrogen and oxygen with atom fractions of 2 and 1 , respectively, and a density of $0.99651 \mathrm{~g} / \mathrm{cc}$. The material composition of type 347 stainless steel is taken from Reference 5 . The density is assumed to be $7.92 \mathrm{~g} / \mathrm{cc}$.

4.2.2.3 Water Reflected 9-, 10-, 11-, and 12-Inch Diameter Cylinders 
This validation contains 14 experiments consisting of water reflected, type 347 stainless steel cylinders filled with plutonium nitrate solutions at 97.10 to $97.15 \% \mathrm{Pu}-239$. The plutonium concentration in the solution is varied $(31.14$ to $99.09 \mathrm{~g} / \mathrm{l})$, the diameter of the cylindrical tanks are varied ( 9 to 12 in), and the critical solution heights are varied $(8.80$ to $17.55 \mathrm{in}$ ). The $\mathrm{H} / \mathrm{Pu}-239$ ratio varied between 266.9 and 849.7 . The isotopic distributions of the plutonium are given in Table 39.

Table 39. Pu Isotopic Distribution for PU-SOL-THERM-010.

\begin{tabular}{|c|c|c|}
\hline Isotope & $\begin{array}{c}\text { Weight } \\
\text { Percent } \\
\text { (Cases 1-8) }\end{array}$ & $\begin{array}{c}\text { Weight } \\
\text { Percent } \\
\text { (Cases 9-14) }\end{array}$ \\
\hline${ }^{239} \mathrm{Pu}$ & 97.15 & 97.10 \\
\hline${ }^{240} \mathrm{Pu}$ & 2.85 & 2.90 \\
\hline
\end{tabular}

The type 347 stainless steel tanks are $0.1575 \mathrm{~cm}$ thick. Immediately above the critical liquid surface in the tanks, a tamper is positioned to provide reflection. The tamper is a type 347 stainless steel cylinder (with no top) containing a $30.48 \mathrm{~cm}$ height of water. An empty, type 347 stainless steel tube runs through the middle of the tamper with inner and outer radii of 1.0465 and $1.3335 \mathrm{~cm}$, respectively. The tank itself extends $97.9488 \mathrm{~cm}$ above the inner surface of the floor of the tank. Above the tamper, the tank is empty. Surrounding the tank and this empty region radially is at least $30 \mathrm{~cm}$ of water, providing infinite reflection. An identical amount of water is present below the tank, as well. Geometry data on critical heights, tank radii, and tamper radii are presented in Table 40.

Table 40. Geometry Data for PU-SOL-THERM-010.

\begin{tabular}{|c|c|c|c|c|c|}
\hline Case & Critical & \multicolumn{2}{|c|}{ Tamper } & \multicolumn{2}{c|}{ Tank } \\
\hline & Height (cm) & IR (cm) & OR (cm) & OR (cm) \\
\hline 1 & 30.7086 & 11.1419 & 11.2994 & 11.4264 & 11.5839 \\
\hline 2 & 35.4076 & 11.1419 & 11.2994 & 11.4264 & 11.5839 \\
\hline 3 & 44.5770 & 11.1419 & 11.2994 & 11.4264 & 11.5839 \\
\hline 4 & 25.6032 & 13.6839 & 13.8414 & 13.9684 & $14.2910^{\mathrm{G}}$ \\
\hline 5 & 28.1686 & 13.6839 & 13.8414 & 13.9684 & $14.2910^{\mathrm{G}}$ \\
\hline 6 & 27.0764 & 13.6839 & 13.8414 & 13.9684 & 14.1259 \\
\hline 7 & 32.6390 & 13.6839 & 13.8414 & 13.9684 & 14.1259 \\
\hline 8 & 43.0022 & 13.6839 & 13.8414 & 13.9684 & 14.1259 \\
\hline 9 & 22.8092 & 13.6839 & 13.8414 & 13.9684 & 14.1259 \\
\hline 10 & 25.9588 & 13.6839 & 13.8414 & 13.9684 & 14.1259 \\
\hline 11 & 22.3520 & 14.9545 & 15.1120 & 15.2390 & 15.3965 \\
\hline 12 & 25.2476 & 14.9545 & 15.1120 & 15.2390 & 15.3965 \\
\hline
\end{tabular}

G In these two experiments, a $0.065^{\prime \prime}$ layer of stainless steel is placed around the cylindrical tank. The ends of the tank are not affected. 


\begin{tabular}{|l|l|l|l|l|l|}
\hline 13 & 28.4734 & 14.9545 & 15.1120 & 15.2390 & 15.3965 \\
\hline 14 & 33.4264 & 14.9545 & 15.1120 & 15.2390 & 15.3965 \\
\hline
\end{tabular}

The material data for the fuel solution given in PU-SOL-THERM-010/Table 3 of Reference 5 . are used to create weight fractions for the fuel solution constituents for input into MCNP. The resulting weight fractions are given in Table 41 , and are equivalent to the atom densities presented in PU-SOL-THERM-010/Table 5 of Reference 5.

Table 41. Fuel Material Weight Fractions for PU-SOL-THERM-010.

\begin{tabular}{|c|c|c|c|c|c|c|c|}
\hline Case & $\rho(\mathrm{g} / \mathrm{cc})$ & $239 \mathrm{Pu}$ & $240 \mathrm{Pu}$ & $\mathrm{N}$ & $\mathrm{H}$ & $\mathbf{O}$ & $\mathrm{Fe}$ \\
\hline 1 & 1.1997 & $8.0242 \mathrm{E}-02$ & $2.3540 \mathrm{E}-03$ & $2.5702 \mathrm{E}-02$ & $9.0291 \mathrm{E}-02$ & $8.0109 \mathrm{E}-01$ & $3.1508 \mathrm{E}-04$ \\
\hline 2 & 1.1592 & $6.1951 \mathrm{E}-02$ & $1.8174 \mathrm{E}-03$ & $2.4476 \mathrm{E}-02$ & $9.3222 \mathrm{E}-02$ & $8.1833 \mathrm{E}-01$ & $1.9928 \mathrm{E}-04$ \\
\hline 3 & 1.1329 & $4.6761 \mathrm{E}-02$ & $1.3718 \mathrm{E}-03$ & $2.3888 \mathrm{E}-02$ & $9.5456 \mathrm{E}-02$ & $8.3229 \mathrm{E}-01$ & $2.2685 \mathrm{E}-04$ \\
\hline 4 & 1.1329 & $4.6676 \mathrm{E}-02$ & $1.3693 \mathrm{E}-03$ & $2.3928 \mathrm{E}-02$ & $9.5450 \mathrm{E}-02$ & $8.3235 \mathrm{E}-01$ & $2.2685 \mathrm{E}-04$ \\
\hline 5 & 1.1202 & $4.0943 \mathrm{E}-02$ & $1.2011 \mathrm{E}-03$ & $2.3594 \mathrm{E}-02$ & $9.6341 \mathrm{E}-02$ & $8.3768 \mathrm{E}-01$ & $2.4549 \mathrm{E}-04$ \\
\hline 6 & 1.1202 & $4.0943 \mathrm{E}-02$ & $1.2011 \mathrm{E}-03$ & $2.3594 \mathrm{E}-02$ & $9.6341 \mathrm{E}-02$ & $8.3768 \mathrm{E}-01$ & $2.4549 \mathrm{E}-04$ \\
\hline 7 & 1.1604 & $3.4937 \mathrm{E}-02$ & $1.0249 \mathrm{E}-03$ & $4.1854 \mathrm{E}-02$ & $8.9250 \mathrm{E}-02$ & $8.3271 \mathrm{E}-01$ & $2.1975 \mathrm{E}-04$ \\
\hline 8 & 1.2022 & $2.9819 \mathrm{E}-02$ & $8.7477 \mathrm{E}-04$ & $5.6371 \mathrm{E}-02$ & $8.3656 \mathrm{E}-02$ & $8.2906 \mathrm{E}-01$ & $2.1877 \mathrm{E}-04$ \\
\hline 9 & 1.1483 & $5.4110 \mathrm{E}-02$ & $1.6160 \mathrm{E}-03$ & $2.3823 \mathrm{E}-02$ & $9.4517 \mathrm{E}-02$ & $8.2567 \mathrm{E}-01$ & $2.5951 \mathrm{E}-04-$ \\
\hline 10 & 1.1360 & $4.1866 \mathrm{E}-02$ & $1.2504 \mathrm{E}-03$ & $2.7641 \mathrm{E}-02$ & $9.4476 \mathrm{E}-02$ & $8.3456 \mathrm{E}-01$ & $2.0951 \mathrm{E}-04$ \\
\hline 11 & 1.1260 & $4.2039 \mathrm{E}-02$ & $1.2556 \mathrm{E}-03$ & $2.3332 \mathrm{E}-02$ & $9.6313 \mathrm{E}-02$ & $8.3686 \mathrm{E}-01$ & $1.9805 \mathrm{E}-04$ \\
\hline 12 & 1.1152 & $3.6822 \mathrm{E}-02$ & $1.0997 \mathrm{E}-03$ & $2.5644 \mathrm{E}-02$ & $9.6002 \mathrm{E}-02$ & $8.4028 \mathrm{E}-01$ & $1.5603 \mathrm{E}-04$ \\
\hline 13 & 1.1077 & $3.2013 \mathrm{E}-02$ & $9.5611 \mathrm{E}-04$ & $2.1841 \mathrm{E}-02$ & $9.8272 \mathrm{E}-02$ & $8.4677 \mathrm{E}-01$ & $1.4535 \mathrm{E}-04$ \\
\hline 14 & 1.1028 & $2.7418 \mathrm{E}-02$ & $8.1888 \mathrm{E}-04$ & $2.3352 \mathrm{E}-02$ & $9.8222 \mathrm{E}-02$ & $8.5005 \mathrm{E}-01$ & $1.3874 \mathrm{E}-04$ \\
\hline
\end{tabular}

\subsubsection{Reflected Slabs of Plutonium Nitrate $\left(\mathrm{Pu}\left(\mathrm{NO}_{3}\right)_{4}\right)$ Solutions}

Thirteen experiments were conducted in a stainless steel slab tank with a 130-cm square base. Critical solution heights were determined for various plutonium nitrate solution compositions. The tank was either fully reflected by water on all six sides or reflected by water on only five sides. The plutonium concentration ranged in this experiment from 13.2 to $105 \mathrm{~g} / \mathrm{l}$. The $\mathrm{H} / \mathrm{Pu}-239$ ratio varied between 309.08 and 2573.31 . The isotopic distributions of the plutonium are given in Table 42 .

Table 42. Pu Isotopic Distribution for PU-SOL-THERM-0125.

\begin{tabular}{|c|c|}
\hline Isotope & Wt \% \\
\hline${ }^{239} \mathrm{Pu}$ & 74.20 \\
\hline${ }^{240} \mathrm{Pu}$ & 18.88 \\
\hline
\end{tabular}


The geometrical data are listed below:

1) The tank, $130 \times 130 \times 100 \mathrm{~cm}$ inside dimensions, $0.5 \mathrm{~cm}$ wall thickness,

2) The water around the tank, in reflected configurations (calculations indicate that a 25 $\mathrm{cm}$ thickness is enough),

3) The Lucoflex box:

floating on the nitrate solution, full of water, in cases of full water reflection positioned at the top $(80 \mathrm{~cm}$ between the bottom of the tank and the lower Lucoflex face):

empty in cases of water reflection on five sides

empty or full of water in cases of no close water reflection

4) The steel pool wall and concrete room wall, ceiling, and floor (calculations indicate that a $50-\mathrm{cm}$ thickness for the concrete is enough) for configurations without close water reflection. The pool is centered in the room.

The fuel material densities are given in Table 43.

Table 43. Fuel Material Atom Densities (atoms/barn-cm) for PU-SOL-THERM-012.

\begin{tabular}{|c|c|c|c|c|c|c|}
\hline Case & Pu-239 & Pu-240 & N & H & O & Fe \\
\hline 1 & & & & & & \\
\hline 2 & $3.68825 \mathrm{E}-05$ & $9.34548 \mathrm{E}-06$ & $1.41344 \mathrm{E}-03$ & $6.34983 \mathrm{E}-02$ & $3.53933 \mathrm{E}-02$ & $4.96028 \mathrm{E}-06$ \\
\hline 3 & $3.12659 \mathrm{E}-05$ & $7.92231 \mathrm{E}-06$ & $1.38532 \mathrm{E}-03$ & $6.36398 \mathrm{E}-02$ & $3.53767 \mathrm{E}-02$ & $4.09762 \mathrm{E}-06$ \\
\hline 4 & $2.75215 \mathrm{E}-05$ & $6.97353 \mathrm{E}-06$ & $1.37017 \mathrm{E}-03$ & $6.36186 \mathrm{E}-02$ & $3.53176 \mathrm{E}-02$ & $3.88196 \mathrm{E}-06$ \\
\hline 5 & $2.47132 \mathrm{E}-05$ & $6.26195 \mathrm{E}-06$ & $1.37165 \mathrm{E}-03$ & $6.35948 \mathrm{E}-02$ & $3.53011 \mathrm{E}-02$ & $3.55846 \mathrm{E}-06$ \\
\hline 6 & $1.96582 \mathrm{E}-04$ & $4.98109 \mathrm{E}-05$ & $2.51393 \mathrm{E}-03$ & $6.07598 \mathrm{E}-02$ & $3.72502 \mathrm{E}-02$ & $2.48014 \mathrm{E}-05$ \\
\hline 7 & $1.57266 \mathrm{E}-04$ & $3.98488 \mathrm{E}-05$ & $2.07086 \mathrm{E}-03$ & $6.19361 \mathrm{E}-02$ & $3.66145 \mathrm{E}-02$ & $2.02724 \mathrm{E}-05$ \\
\hline 8 & $9.86655 \mathrm{E}-05$ & $2.50004 \mathrm{E}-05$ & $1.78497 \mathrm{E}-03$ & $6.24015 \mathrm{E}-02$ & $3.59564 \mathrm{E}-02$ & $1.21850 \mathrm{E}-05$ \\
\hline 9 & $5.97235 \mathrm{E}-05$ & $1.51330 \mathrm{E}-05$ & $1.56626 \mathrm{E}-03$ & $6.29542 \mathrm{E}-02$ & $3.55707 \mathrm{E}-02$ & $7.54825 \mathrm{E}-06$ \\
\hline 10 & $5.03624 \mathrm{E}-05$ & $1.27611 \mathrm{E}-05$ & $1.52854 \mathrm{E}-03$ & $6.30426 \mathrm{E}-02$ & $3.54927 \mathrm{E}-02$ & $6.36209 \mathrm{E}-06$ \\
\hline 11 & $4.06270 \mathrm{E}-05$ & $1.02943 \mathrm{E}-05$ & $1.41749 \mathrm{E}-03$ & $6.36500 \mathrm{E}-02$ & $3.54903 \mathrm{E}-02$ & $5.39161 \mathrm{E}-06$ \\
\hline 12 & $3.68825 \mathrm{E}-05$ & $9.34548 \mathrm{E}-06$ & $1.41344 \mathrm{E}-03$ & $6.34983 \mathrm{E}-02$ & $3.53933 \mathrm{E}-02$ & $4.96028 \mathrm{E}-06$ \\
\hline 13 & $2.47132 \mathrm{E}-05$ & $6.26195 \mathrm{E}-06$ & $1.37165 \mathrm{E}-03$ & $6.35948 \mathrm{E}-02$ & $3.53011 \mathrm{E}-02$ & $3.55846 \mathrm{E}-06$ \\
\hline
\end{tabular}




\subsubsection{Bias and Uncertainty}

Table 44 gives a summary of the evaluated experiments and the associated average $k_{\text {eff }}$ from each set.

Table 44. Computed $k_{\text {eff }}$ Values for Plutonium Solutions.

\begin{tabular}{|c|c|c|}
\hline Experiment & Description & $\mathbf{A v g} \mathbf{k}_{\text {eff }}$ \\
\hline PU-SOL-THERM-001 & 11.5" Water-reflected Spheres & 1.0107 \\
\hline PU-SOL-THERM-002 & 12" Water-reflected Spheres & 1.0113 \\
\hline PU-SOL-THERM-003 & 13" Water-reflected Spheres & 1.0117 \\
\hline PU-SOL-THERM-004 & 14" Water-reflected Spheres & 1.0094 \\
\hline PU-SOL-THERM-005 & $\begin{array}{l}15 " \text { Water-reflected Spheres of } 4.05 \% \\
\text { and } 4.40 \%{ }^{240} \mathrm{Pu}\end{array}$ & 1.0105 \\
\hline PU-SOL-THERM-006 & 15" Water-reflected Spheres & 1.0092 \\
\hline PU-SOL-THERM-007 & $\begin{array}{c}\text { 11.5" Water-reflected partially-filled } \\
\text { spheres }\end{array}$ & 1.0070 \\
\hline PU-SOL-THERM-009 & $48^{\prime \prime}$ Unreflected Spheres & 1.0224 \\
\hline PU-SOL-THERM-010 & $\begin{array}{c}9,10,11 \text {, and } 12 " \text { Water-reflected } \\
\text { Cylinders }\end{array}$ & 1.0160 \\
\hline PU-SOL-THERM-011 & 16" Unreflected Spheres & 1.0200 \\
\hline PU-SOL-THERM-011 & 18" Unreflected Spheres & 1.0050 \\
\hline PU-SOL-THERM-012 & Pu slabs-reflected & 1.0130 \\
\hline
\end{tabular}

The 48-inch spheres calculate significantly higher results than the other experiments. Slab experiments approaching the $\mathrm{H} / \mathrm{Pu}-239$ ratios represented by the spheres calculate lower, but their higher $\mathrm{Pu}-240$ content may cloud the comparison. The 48 -inch results were used in this validation; however, caution should be used when using bias results with H/Pu-239 greater than 2000 until the number of data points in this region has been increased.

The handbook ${ }^{5}$ recommends not using the 16 -inch spheres for validation if the resulting $\mathrm{k}_{\text {eff }}$ 's are higher than the results of similar experiments. The average values for these cases are approximately $1.5 \%$ higher than the average of the 18 -inch cases. Therefore, the results from the 16-inch spheres are not included in the bias calculations.

Some of the 18-inch cadmium reflected spheres calculate values lower than the results from the other experiments. The average $k_{\text {eff }}$ of 1.0050 for these spheres is 0.0072 lower than the average $k_{\text {eff }}$ for the rest of the experiments. This result does not appear to be the result of the cadmium shell around the spheres. Removal of the shell from the experimental models results in a statistically insignificant change in the $k_{\text {eff }}$. These 
experiments were retained because their net effect would be to reduce the positive bias (conservative). The inclusion of the cadmium reflected spheres in this validation should not be considered an adequate test of the cadmium cross sections (i.e., its presence is not statistically significant).

A computational bias is determined by statistically analyzing the calculated $k_{\text {eff }}$ values from the benchmark experiments. In accordance to Reference 4, a Chi-square test is performed to determine if the data are normally distributed. This distribution is determined to be non-normal. The plot of the $\mathrm{k}_{\mathrm{eff}}$ values versus the $\mathrm{H} / \mathrm{Pu}$ ratio is shown in Figure 2.

\section{PU-SOL-THERM}

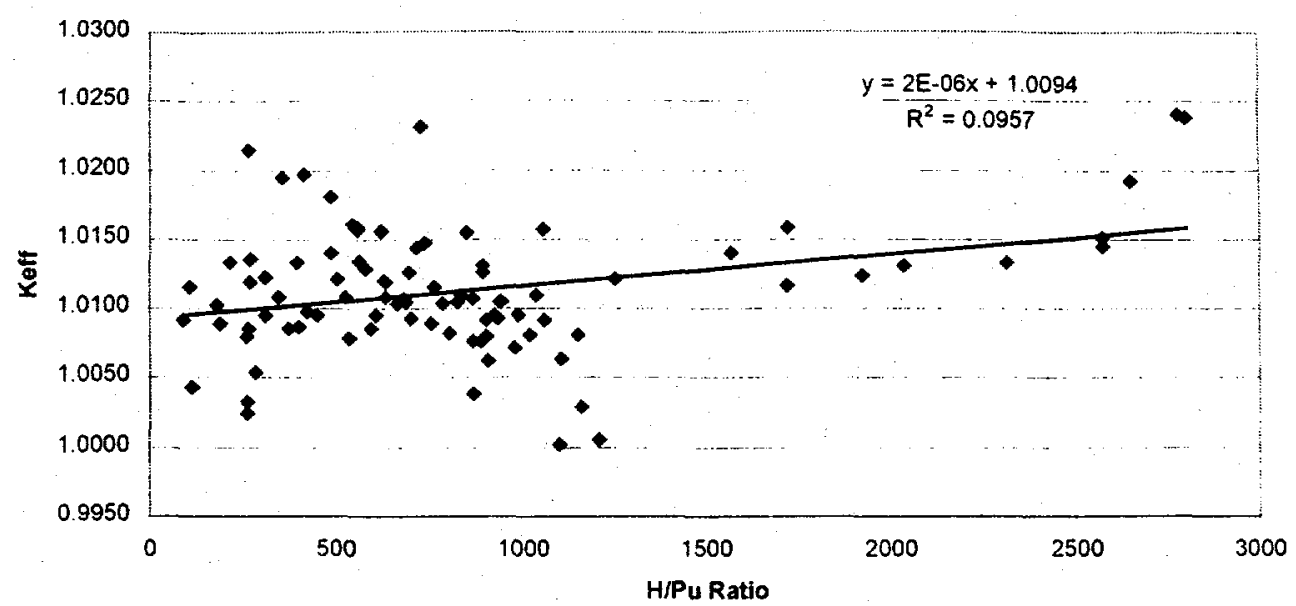

Figure 2. $K_{\text {eff }}$ versus H/Pu Ratio.

A non-parametric upper subcritical limit was calculated due to the non-normal distribution of the data and the poor fit of the trendline to the data series $\left(R^{2}=0.0957\right)$. An attempt to fit this data to the curves specified in Reference 4 also failed. With a data set of 91 , there is a $99.1 \%$ confidence that $95 \%$ of the data lies above the smallest value as suggested by Equation 2 .

$$
\beta=1-(q)^{n}
$$

where $\quad q=$ desired population fraction (normally 0.95 )

$\mathrm{n}=$ number of data samples

The non-parametric margin for this level of confidence is 0.0 (see section 2.9.1 of Reference 4). Therefore, the upper subcritical limit can be calculated from Equation 3 as follows: 


$$
\begin{gathered}
\mathrm{k}_{\text {limit }}=\text { smallest } \mathrm{k}_{\text {eff }} \text { value }- \text { bias uncertainty }- \text { non-parametric margin } \\
=1.0000-\sqrt{(0.0052)^{2}+(0.0012)^{2}}-0.0=0.9947
\end{gathered}
$$

(Note: 1.0 is the maximum acceptable smallest value for $\mathrm{k}_{\text {eff }}$; i.e., positive bias is not allowed)

The upper subcritical limit for the plutonium solution systems is 0.994 . 


\subsubsection{Limitations}

The data used in this validation covers a broad spectrum of materials with various $\mathrm{Pu}-240$ contents. The Pu-240 content ranged from $0.54-18.91 \%$, with the majority of the experiments having $\mathrm{Pu}-240$ content of $2.5-4.7 \%$. Thirteen experiments had a $\mathrm{Pu}-240$ content near $19 \%$.

The upper subcritical limit developed is applicable to unreflected and water reflected systems of plutonium nitrate solutions as evaluated on the WSMS DEC Alpha workstation. These results are not applicable to plutonium metal systems or to plutonium solution systems with significant non-water reflectors. Use of these results with systems containing different reflectors requires additional analysis and justification.

Use of the results with $\mathrm{H} / \mathrm{Pu}-239$ ratios above 2000 is strongly cautioned and requires the use of an area of applicability margin ( $\mathrm{AOA})^{4}$. The results in this region are based on two sets of experiments that span a range of $1.4 \%$ of $\mathrm{k}_{\mathrm{eff}}$. Additional analysis and justification are recommended prior to using the results from this region. 


\subsection{URANIUM SYSTEMS}

\subsection{Uranium Metal (Fast) ${ }^{6}$}

\subsubsection{Area of Applicability}

This section presents the MCNP validation analysis for reflected and unreflected highly enriched uranium metal systems. The result from this analysis is an upper subcritical limit for the MCNP code system with the ENDF/B-V cross section library. The MCNP user should employ the F-4 flux tally to obtain the average energy to assure that the evaluated system is contained within the applicable neutron spectrum. Key areas of applicability for these experiments include:

1. Fuel:

2. Moderation:

3. Enrichment:

4. Moderating Material:

5. Reflector Material:

6. Geometry:

7. Neutron Spectrum ${ }^{\mathrm{H}}$ :
Highly enriched uranium metal

H/U-235: $\sim 0$

$\sim 37 \%$ U-235 for IEU, $\sim 90-97 \%$ U-235 for HEU

Polyethylene, Plexiglas, Teflon, $\mathrm{Ti}, \mathrm{Al}$, and steel

Bare, water, U-238, Polyethylene, Paraffin, Lucite, Tungsten Carbide, Steel, Al, or Tuballoy

Single spherical units, arrays of cylinders, slabs, pseudo-spheres, cylinders, parallelepipeds Intermediate-Fast; $2.0 \mathrm{eV}-1.5 \mathrm{MeV}$

AEG: $4.84-15.81$

\subsubsection{System Description}

One hundred and thirty uranium metal critical experiments were extracted from the International Handbook of Evaluated Criticality Benchmark Experiments for this evaluation. The experiments were divided into two categories: single unit systems, and array systems. The single unit systems used in this report include two experiments from HEU-MET-FAST-00 $1^{5}$, six from HEU-MET-FAST-002 $2^{5}$ eleven from HEU-METFAST- $003^{5}$, one from HEU-MET-FAST-004, and forty-three from HEU-MET-FAST$007^{5}$. Also included are thirteen single unit systems from Russian experiments. The array systems consist of 22 experiments from HEU-MET-FAST-023 ${ }^{5}$ and 32 from HEUMET-FAST- $026^{5}$. The experimental configurations for these experiments are described in the following sections.

\subsubsection{Single Unit Systems}

The single unit experiment sets contain five different configuration systems. Four experiment sets (HEU-MET-FAST-001, -002, -003, and -004) were performed at Los Alamos National Laboratory (LANL). The next experiment set (HEU-MET-FAST-007)

\footnotetext{
${ }^{\mathrm{H}}$ The neutron spectrum represents the average energy of the neutrons causing fission.
} 
was performed at the Oak Ridge National Laboratory (ORNL). The last experimental sets (HEU-MET-FAST $-012^{j},-013^{j},-021^{5},-022^{5},-024^{5},-033^{j},-034^{j},-035^{j}$, and IEU-MET-FAST $-005^{5}$ and $\left.-006^{5}\right)$ were performed at the Russian Federal Nuclear Institutes of Technical Physics (VNIITF and VNIIEF).

\subsection{Unreflected HEU Spheres}

Two experiments involved unreflected uranium spheres. The first, referred to as Godiva, was performed with a bare uranium sphere. The second experiment was a Shell Model involving layers of uranium with gaps of air. Both experiments consisted of two identical sets of nested oralloy hemispheres. In this setup, a 0.015 -inch-thick diaphragm of stainless steel supported the upper hemisphere, while the lower hemisphere rested on a thin-wall aluminum cylinder. A summary of the experimental parameters for these experiments is provided in Table 47.

Table 47. Reported Parameters for HEU-MET-FAST-001.

\begin{tabular}{|c|c|c|c|c|c|}
\hline $\begin{array}{c}\text { Benchmark } \\
\text { Descriptor }\end{array}$ & Composition & \multicolumn{3}{|c|}{ U Isotopic Composition } & Sphere Radius (cm) \\
\hline & & $\mathbf{2 3 4}$ & $\mathbf{2 3 5}$ & $\mathbf{2 3 8}$ & \\
\hline Godiva & HEU & 1.02 & 93.71 & 5.27 & 8.7407 \\
\hline Shell Model: & & & & & \\
\hline Shell 1 & HEU & 1.02 & 93.26 & 5.72 & 1.0216 \\
\hline Shell 2 & Air gap & - & - & - & 1.0541 \\
\hline Shell 3 & HEU & 1.02 & 93.90 & 5.08 & 6.2809 \\
\hline Shell 4 & Air gap & - & - & - & 6.2937 \\
\hline Shell 5 & HEU & 1.02 & 93.95 & 5.03 & 7.7525 \\
\hline Shell 6 & Air gap & - & - & - & 7.7620 \\
\hline Shell 7 & HEU & 1.02 & 93.58 & 5.40 & 8.2527 \\
\hline Shell 8 & Air gap & - & - & - & 8.2610 \\
\hline Shell 9 & HEU & 1.02 & 93.89 & 5.09 & 8.7062 \\
\hline Shell 10 & HEU & 1.02 & 93.86 & 5.12 & 8.7499 \\
\hline
\end{tabular}

\subsection{Natural Uranium-Reflected Pseudosphere, Pseudocylinder, and Parallelepipeds}

Six experiments involving tuballoy-reflected critical assemblies were run on the Topsy machine. This set of oralloy assemblies includes a pseudosphere, a pseudocylinder, and four parallelepipeds. The density of oralloy in all six assemblies is $18.75 \mathrm{~g} / \mathrm{cm}^{3}$, and it is composed of $93.5 \mathrm{wt} \% \mathrm{U}-235,1.02 \mathrm{wt} \% \mathrm{U}-234$, and $5.48 \mathrm{wt} \% \mathrm{U}-238$. The tuballoy reflector has a density of $18.90 \mathrm{~g} / \mathrm{cm}^{3}$, and is composed of 0.0055 at $\% \mathrm{U}-234,0.72$ at $\%$ U-235, and 99.2745 at \% U-238. A summary of the experimental parameters for these experiments is provided in Table 48. 
Table 48. Reported Parameters for HEU-MET-FAST-002.

\begin{tabular}{|c|c|c|c|c|c|c|}
\hline \hline Configuration & Region & $\begin{array}{c}\text { Width } \\
\text { (cm) }\end{array}$ & $\begin{array}{c}\text { Depth } \\
(\mathbf{c m})\end{array}$ & $\begin{array}{c}\text { Height } \\
(\mathbf{c m})\end{array}$ & $\begin{array}{c}\text { Radius } \\
(\mathbf{c m})\end{array}$ & Material \\
\hline Sphere & 1 & - & - & - & 6.0509 & Oralloy \\
\hline & 2 & - & - & - & 26.3709 & Tuballoy \\
\hline Cylinder & 1 & - & - & 11.43 & 5.1706 & Oralloy \\
\hline & 2 & - & - & $52.07^{1}$ & 25.4906 & Tuballoy \\
\hline $\begin{array}{l}4 \times 4 \times 3.66 \text { Inch } \\
\text { Parallelepiped }\end{array}$ & 1 & 10.16 & 10.16 & 9.3 & - & Oralloy \\
\hline & 2 & 50.80 & 50.80 & 49.94 & - & Tuballoy \\
\hline $\begin{array}{l}5 \times 5 \times 2.53 \text { Inch } \\
\text { Parallelepiped }\end{array}$ & 1 & 12.70 & 12.70 & 6.415 & - & Oralloy \\
\hline & 2 & 53.34 & 53.34 & 47.0550 & - & Tuballoy \\
\hline \hline $\begin{array}{l}3 \times 3 \times 7.56 \text { Inch } \\
\text { Parallelepiped }\end{array}$ & 1 & 7.62 & 7.62 & 19.1970 & - & Oralloy \\
\cline { 2 - 7 } & 2 & 48.26 & 48.26 & 59.8370 & - & Tuballoy \\
\hline \hline $\begin{array}{l}3 \times 3.5 \times 6 \text { Inch } \\
\text { Parallelepiped }\end{array}$ & 1 & 7.62 & 8.89 & 15.2344 & - & Oralloy \\
\cline { 2 - 7 } & 2 & 48.26 & 49.53 & 55.8744 & - & Tuballoy \\
\hline
\end{tabular}

Table 49 lists the atom densities for the different isotopes.

Table 49. Atom Densities.

\begin{tabular}{|l|c|c|}
\hline Material & Isotope & $\begin{array}{c}\text { Concentration } \\
\text { (atoms/barn-cm) }\end{array}$ \\
\hline Oralloy & ${ }^{234} \mathrm{U}$ & $4.9210 \times 10^{-4}$ \\
\hline & ${ }^{235} \mathrm{U}$ & $4.4917 \times 10^{-2}$ \\
\hline & ${ }^{238} \mathrm{U}$ & $2.5993 \times 10^{-3}$ \\
\hline Tuballoy & ${ }^{234} \mathrm{U}$ & $2.6299 \times 10^{-6}$ \\
\hline & ${ }^{235} \mathrm{U}$ & $3.4428 \times 10^{-4}$ \\
\hline & ${ }^{238} \mathrm{U}$ & $4.7470 \times 10^{-2}$ \\
\hline
\end{tabular}

' $20.32 \mathrm{~cm}$ above and below region 1. 


\subsection{Unmoderated, Reflected HEU Spheres}

Twelve experiments, taken from HEU-MET-FAST-003, involved unmoderated, reflected spherical assemblies. The setup included seven spherical oralloy assemblies reflected by tuballoy, four spherical oralloy assemblies reflected by tungsten carbide, and one spherical oralloy assembly reflected by nickel. The density of the oralloy was 18.75 $\mathrm{g} / \mathrm{cm}^{3}$, with constituents of 1.02 wt \% U-234, 93.5 wt \% U-235, and 5.48 wt $\%$ U-238. The density of the tuballoy was $18.90 \mathrm{~g} / \mathrm{cm} 3$. Tables 50 and 51 contain the isotopic abundance for the uranium and tungsten reflectors.

Table 50. Isotopic Abundance (at \%) for Uranium Reflector.

\begin{tabular}{|c|c|}
\hline Isotope & Abundance (at \%) \\
\hline${ }^{234} \mathrm{U}$ & 0.0055 \\
\hline${ }^{235} \mathrm{U}$ & 0.72 \\
\hline${ }^{238} \mathrm{U}$ & 99.2745 \\
\hline
\end{tabular}

Table 51. Isotopic Abundance (at \%) for Tungsten Reflector.

\begin{tabular}{|c|c|}
\hline Isotope & Abundance (at \%) \\
\hline${ }^{180} \mathrm{~W}$ & 0.12 \\
\hline${ }^{182} \mathrm{~W}$ & 26.3 \\
\hline${ }^{183} \mathrm{~W}$ & 14.28 \\
\hline${ }^{184} \mathrm{~W}$ & 30.7 \\
\hline${ }^{186} \mathrm{~W}$ & 28.6 \\
\hline
\end{tabular}

A summary of the experimental parameters for these experiments is provided in Table 52. Region 1 refers to the spherical oralloy, while region 2 denotes the reflector. 
Table 52. Reported Parameters for HEU-MET-FAST-003.

\begin{tabular}{|c|c|c|c|}
\hline $\begin{array}{c}\text { Reflector Thickness } \\
\text { (in.) }\end{array}$ & Region & Outer Radius (cm.) & Material \\
\hline 2.0 & 1 & 6.7820 & Oralloy \\
\hline & 2 & 11.8620 & Tuballoy \\
\hline 3.0 & 1 & 6.4423 & Oralloy \\
\hline 4.0 & 2 & 14.0623 & Tuballoy \\
\hline & 1 & 6.2851 & Oralloy \\
\hline 5.0 & 2 & 16.4451 & Tuballoy \\
\hline & 1 & 6.1535 & Oralloy \\
\hline 7.0 & 2 & 18.8535 & Tuballoy \\
\hline & 1 & 6.0740 & Oralloy \\
\hline 8.0 & 2 & 23.8540 & Tuballoy \\
\hline & 1 & 6.0509 & Oralloy \\
\hline 11.0 & 2 & 26.3709 & Tuballoy \\
\hline & 1 & 6.0276 & Oralloy \\
\hline 1.9 & 2 & 33.9676 & Tuballoy \\
\hline & 1 & 6.6020 & Oralloy \\
\hline 2.9 & 2 & 11.4280 & Tungsten Carbide \\
\hline & 1 & 6.2527 & Oralloy \\
\hline 4.5 & 2 & 13.6187 & Tungsten Carbide \\
\hline 6.5 & 1 & 6.0509 & Oralloy \\
\hline & 2 & 17.4809 & Tungsten Carbide \\
\hline 8.0 & 1 & 6.0159 & Oralloy \\
\hline & 2 & 22.5259 & Tungsten Carbide \\
\hline & 1 & 6.4627 & Oralloy \\
\hline & 2 & 26.7827 & Nickel \\
\hline
\end{tabular}

Table 53 gives the atom densities for the four different reflectors. 
Table 53. Atom Densities.

\begin{tabular}{|c|c|c|}
\hline Material & Isotope & $\begin{array}{c}\text { Concentration } \\
\text { (atoms/barn-cm) }\end{array}$ \\
\hline Oralloy & ${ }^{234} \mathrm{U}$ & $4.9210 \times 10^{-4}$ \\
\hline & ${ }^{23} \mathrm{U}$ & $4.4917 \times 10^{-2}$ \\
\hline & ${ }^{238} \mathrm{U}$ & $2.5993 \times 10^{-3}$ \\
\hline Tuballoy & ${ }^{234} \mathrm{U}$ & $2.6299 \times 10^{-6}$ \\
\hline & ${ }^{23} \mathrm{U}$ & $3.4428 \times 10^{-4}$ \\
\hline $\begin{array}{c}\text { Tungsten Carbide } \\
\text { (WC) }\end{array}$ & ${ }^{238} \mathrm{U}$ & $4.7470 \times 10^{-2}$ \\
\hline & ${ }^{182} \mathrm{~W}$ & $1.2697 \times 10^{-2}$ \\
\hline & ${ }^{183} \mathrm{~W}$ & $6.8626 \times 10^{-3}$ \\
\hline & ${ }^{184} \mathrm{~W}$ & $1.4754 \times 10^{-2}$ \\
\hline & ${ }^{18} \mathrm{~W}$ & $1.3744 \times 10^{-2}$ \\
\hline Nickel & $\mathrm{C}$ & $4.8057 \times 10^{-2}$ \\
\hline
\end{tabular}

Seven experiments containing unmoderated, reflected spheres were also performed at the Russian facilities. A description of each is listed below in Table 54.

Table 54. Description of Russian Experiments.

\begin{tabular}{|c|l|}
\hline Handbook I.D. & \multicolumn{1}{|c|}{ Experiment Description } \\
\hline HEU-MET-FAST-012 & $\begin{array}{l}\text { This experiment, conducted at the Russian Federal Nuclear Center Institute of } \\
\text { Technical Physics (VNIITF), was a two-unit assembly consisting of twelve spherical } \\
\text { layers of highly enriched uranium and an aluminum reflector. The bottom reflector } \\
\text { has one shell; the reflector on the top hemisphere has three shells. In the experiment, } \\
\text { top part of the assembly rested on a steel diaphragm while the lower part was raised } \\
\text { into a critical configuration. }\end{array}$ \\
\hline HEU-MET-FAST-013 & $\begin{array}{l}\text { This experiment, conducted at VNIITF, was a two-unit assembly consisting of nine } \\
\text { spherical layers of highly enriched uranium and a four-layer aluminum reflector. The } \\
\text { top part of the assembly rested on a steel diaphragm, while the lower part was raised } \\
\text { into a critical configuration. }\end{array}$ \\
\hline HEU-MET-FAST-021 & $\begin{array}{l}\text { This experiment, conducted at VNIIEF, was a two-unit assembly consisted of seven } \\
\text { spherical layers of highly enriched uranium with a central cavity and steel reflector. } \\
\text { The upper unit consisted of a hemispherical steel shell resting on a steel diaphragm, } \\
\text { and the movable lower unit incorporated the remainder of the core and reflector. }\end{array}$ \\
\hline
\end{tabular}


Table 54. Description of Russian Experiments (continued).

\begin{tabular}{|l|l|}
\hline \multicolumn{1}{|c|}{ Handbook I.D. } & \multicolumn{1}{c|}{ Experiment Description } \\
\hline HEU-MET-FAST-022 & $\begin{array}{l}\text { This experiment, conducted at VNIIEF, consisted of two units: an upper unit } \\
\text { composed of a hemispherical shell of highly enriched uranium and three hemispherical } \\
\text { shells of the Duralumin reflector, and a movable lower unit containing the remainder } \\
\text { of the core and reflector. An aluminum diaphragm supported the upper unit. }\end{array}$ \\
\hline HEU-MET-FAST-024 & $\begin{array}{l}\text { This experiment, performed at VNIITF, was a two-unit assembly consisting of ten } \\
\text { spherical layers of highly enriched uranium, a single-layer steel reflector, and a three- } \\
\text { layer polyethylene reflector. }\end{array}$ \\
\hline IEU-MET-FAST-005 & $\begin{array}{l}\text { This critical experiment, conducted at VNIIEF, consisted of two units: an upper unit } \\
\text { comprised of three hemispherical shells of steel reflector on a steel diaphragm, and the } \\
\text { movable lower unit containing the remainder of the core and reflector. }\end{array}$ \\
\hline IEU-MET-FAST-006 & $\begin{array}{l}\text { This critical experiment, conducted at VNIIEF, consisted of two units: an upper unit } \\
\text { comprised of five hemispherical shells of Duralumin reflector on a steel diaphragm, } \\
\text { and the movable lower unit containing the remainder of the core and reflector. }\end{array}$ \\
\hline
\end{tabular}

Table 55 gives the material composition and dimensions for the evaluated experiments. 
Table 55. Uranium Metal System Compositions and Dimensions.

\begin{tabular}{|c|c|c|c|c|c|c|}
\hline Handbook I.D. & $\begin{array}{c}\text { Core Material } \\
\text { Composition and } \\
\text { Density (wt \%,g/cc) }\end{array}$ & $\begin{array}{l}\text { Uranium Isotopic } \\
\text { Composition(wt \%) }\end{array}$ & $\begin{array}{c}\text { Core } \\
\text { Material }\end{array}$ & $\begin{array}{l}\text { Core } \\
\text { Radius } \\
\text { (cm) }\end{array}$ & $\begin{array}{l}\text { Reflector } \\
\text { Material }\end{array}$ & $\begin{array}{l}\text { Reflector } \\
\text { Thickness } \\
\text { (cm) }\end{array}$ \\
\hline HEU-MET-FAST-012 & $\begin{array}{c}U=99.2626 \\
\mathrm{C}=0.0428 \\
\mathrm{Fe}=0.0698 \\
\mathrm{~W}=0.0211 \\
\mathrm{Cu}=0.4226 \\
\mathrm{Ni}=0.1811 \\
\text { Density }=17.9924\end{array}$ & $\begin{array}{c}{ }^{234} U=1.1369 \\
{ }^{235} U=89.5982 \\
{ }^{236} U=0.1931 \\
{ }^{238} U=9.0772\end{array}$ & $\begin{array}{l}\text { Uranium } \\
\text { Metal }\end{array}$ & 9.15 & Aluminum & $\begin{array}{l}\text { Top }=2.85 \\
\text { Bottom }=1.7\end{array}$ \\
\hline HEU-MET-FAST-013 & $\begin{array}{c}\mathrm{U}=99.2538 \\
\mathrm{C}=0.0443 \\
\mathrm{Fe}=0.0698 \\
\mathrm{~W}=0.0211 \\
\mathrm{Cu}=0.4277 \\
\mathrm{Ni}=0.1833 \\
\text { Density }=17.9924\end{array}$ & $\begin{array}{l}{ }^{234} U=1.1362 \\
{ }^{235} U=89.6324 \\
{ }^{236} U=0.1941 \\
{ }^{238} U=9.0730\end{array}$ & $\begin{array}{c}\text { Uranium } \\
\text { Metal }\end{array}$ & 8.38 & steel & 3.65 \\
\hline $\begin{array}{l}\text { HEU-MET-FAST-021 } \\
\text { (average values used } \\
\text { in the simplified } \\
\text { benchmark model) }\end{array}$ & $\begin{array}{c}\mathrm{U}=99.6921 \\
\mathrm{C}=0.1185 \\
\mathrm{Fe}=0.098 \\
W=0.0914 \\
\text { Density }=18.38\end{array}$ & $\begin{array}{c}{ }^{234} U=1.1045 \\
{ }^{235} U=89.49 \\
{ }^{238} U=9.4064\end{array}$ & $\begin{array}{l}\text { Uranium } \\
\text { Metal }\end{array}$ & 7.55 & steel & $\begin{array}{r}9.7 \\
-\end{array}$ \\
\hline $\begin{array}{l}\text { HEU-MET-FAST-022 } \\
\text { (average values used } \\
\text { in the simplified } \\
\text { benchmark model) }\end{array}$ & $\begin{array}{c}\mathrm{U}=99.7072 \\
\mathrm{C}=.1137 \\
\mathrm{Fe}=.0933 \\
\mathrm{~W}=.0858 \\
\text { Density }=18.4\end{array}$ & $\begin{array}{c}{ }^{234} U=1.104 \\
{ }^{235} U=89.4927 \\
{ }^{238} U=9.403\end{array}$ & $\begin{array}{l}\text { Uranium } \\
\text { Metal }\end{array}$ & 8.35 & Duralumin & 3.9 \\
\hline HEU-MET-FAST-024 & $\begin{array}{c}\mathrm{U}=99.2144 \\
\mathrm{C}=0.0447 \\
\mathrm{Fe}=0.0733 \\
\mathrm{~W}=0.0210 \\
\mathrm{Cu}=0.4525 \\
\mathrm{Ni}=0.1939 \\
\text { Density }=18.0044\end{array}$ & $\begin{array}{l}{ }^{234} U=1.1298 \\
{ }^{235} U=89.5252 \\
{ }^{236} U=0.1970 \\
{ }^{238} U=9.0502\end{array}$ & $\begin{array}{l}\text { Uranium } \\
\text { Metal }\end{array}$ & 7.55 & $\begin{array}{l}\text { Steel and } \\
\mathrm{CH}_{2}\end{array}$ & $\begin{array}{l}0.8 \text { and } 9.65 \text {, } \\
\text { respectively }\end{array}$ \\
\hline $\begin{array}{l}\text { IEU-MET-FAST-005 } \\
\text { (average values used } \\
\text { in the simplified } \\
\text { benchmark model) }\end{array}$ & $\begin{array}{c}\mathrm{U}=99.5429 \\
\mathrm{C}=.0703 \\
\mathrm{Fe}=.062 \\
\mathrm{~W}=.0178 \\
\mathrm{Cu}=.1535 \\
\mathrm{Ni}=.1535 \\
\text { Density }=18.42\end{array}$ & $\begin{array}{l}{ }^{234} U=.3287 \\
{ }^{235} U=36.5129 \\
{ }^{238} U=63.1575\end{array}$ & $\begin{array}{c}\text { Uranium } \\
\text { Metal }\end{array}$ & 13.25 & steel & 8.25 \\
\hline $\begin{array}{l}\text { IEU-MET-FAST-006 } \\
\text { (average values used } \\
\text { in the simplified } \\
\text { benchmark model) }\end{array}$ & $\begin{array}{c}U=99.5435 \\
C=.0702 \\
F e=.0621 \\
W=.0178 \\
C u=.1532 \\
N i=.1532 \\
\text { Density }=18.43\end{array}$ & $\begin{array}{l}{ }^{234} U=.3288 \\
{ }^{235} U=36.5122 \\
{ }^{238} U=63.1586\end{array}$ & $\begin{array}{l}\text { Uranium } \\
\text { Metal }\end{array}$ & 13.25 & Duralumin & 11.75 \\
\hline
\end{tabular}




\subsection{Water-Reflected HEU Sphere}

One experiment involved a water-reflected uranium sphere consisting of two hemispheres of highly enriched uranium. The hemispheres were joined together using a small pin of enriched uranium to form a near-uniform sphere with a radius of $6.5537 \mathrm{~cm}$. The sphere was placed on a plexiglas stand inside a cylindrical aluminum tank. Input files were used to perform calculations for both, one-dimensional and three dimensional, idealizations of the system. The one-dimensional experimental procedure omits the plexiglas stand, and uses a spherical water reflector that preserves the volume of the actual cylindrical reflector. The 1-D idealization was not included in the validation, as there were no experimental results with which to compare it against. The geometrical dimensions and materials and the isotopic concentrations are shown in Tables 56 and 57, respectively.

Table 56. Geometrical Dimensions and Material for HEU-MET-FAST-004.

\begin{tabular}{|c|c|c|c|}
\hline Item & Hemisphere 1 & Hemisphere 2 & Pin \\
\hline Net Mass (kg) & 11.335 & 11.336 & 0.013 \\
\hline Uranium Mass (kg) & 11.328 & 11.331 & 0.013 \\
\hline${ }^{233} \mathrm{U}$ (wt \%) & $<0.01$ & $<0.01$ & $<0.01$ \\
\hline${ }^{234} \mathrm{U}$ (wt \%) & 1.17 & 1.05 & 1.04 \\
\hline${ }^{235} \mathrm{U}$ (wt \%) & 97.67 & 97.68 & 97.67 \\
\hline${ }^{236} \mathrm{U}$ (wt \%) & 0.20 & 0.20 & 0.21 \\
\hline${ }^{238} \mathrm{U}$ (wt \%) & 0.95 & 1.06 & 1.07 \\
\hline
\end{tabular}

Table 57. Isotopic Concentrations for HEU-MET-FAST-004.

\begin{tabular}{|c|c|c|}
\hline Material & Isotope & $\begin{array}{c}\text { Atom Density } \\
\text { (atoms/barn-cm) }\end{array}$ \\
\hline HEU & ${ }^{234} \mathrm{U}$ & $5.3678 \times 10^{-4}$ \\
\hline & ${ }^{235} \mathrm{U}$ & $4.7033 \times 10^{-2}$ \\
\hline & ${ }^{236} \mathrm{U}$ & $9.5896 \times 10^{-5}$ \\
\hline Plexiglas & ${ }^{238} \mathrm{U}$ & $4.7782 \times 10^{-4}$ \\
\hline & ${ }^{1} \mathrm{H}$ & $5.7745 \times 10^{-2}$ \\
\hline & & $3.6090 \times 10^{-2}$ \\
\hline Water & ${ }^{12} \mathrm{C}$ & $1.4435 \times 10^{-2}$ \\
\hline & ${ }^{16} \mathrm{O}$ & $6.6807 \times 10^{-2}$ \\
\hline & ${ }^{1} \mathrm{H}$ & $3.3403 \times 10^{-2}$ \\
\hline
\end{tabular}




\subsection{Moderated, Reflected and Unreflected HEU Slabs}

Forty-three of the experiments involved moderated slabs of highly enriched uranium metal (1.07 wt \% U-234, 93.15 wt \% U-235, $0.68 \mathrm{wt} \% \mathrm{U}-236$, and $5.10 \mathrm{wt} \% \mathrm{U}-238$ ). The unreflected experiments consisted of uranium metal slabs interleaved with polyethylene, Plexiglas, or Teflon. Some of the experiments being moderated by polyethylene also had a six-inch polyethylene reflector. Densities of the three moderator types are shown in Table 58.

Table 58. Densities of Moderators in HEU-MET-FAST-007.

\begin{tabular}{|c|c|}
\hline Moderator & Density $\left(\mathrm{g} / \mathrm{cm}^{3}\right)$ \\
\hline Polyethylene $\left(\mathrm{CH}_{2}\right)$ & 0.92 \\
\hline Plexiglas $\left(\mathrm{C}_{5} \mathrm{O}_{2} \mathrm{H}_{8}\right)$ & 1.18 \\
\hline Teflon $\left(\mathrm{CF}_{2}\right)$ & 2.17 \\
\hline
\end{tabular}

The experiments were performed on the Split Table Apparatus, which consists of two cast iron bench plates, one stationary and one moveable. Table 59 contains the parameters for these forty-three experiments. 
Table 59. Experimental Parameters for HEU-MET-FAST-007.

\begin{tabular}{|c|c|c|c|c|c|c|c|}
\hline \multirow[t]{2}{*}{$\begin{array}{c}\text { Case } \\
\text { Number }\end{array}$} & \multirow[t]{2}{*}{$\begin{array}{l}\text { Height } \\
\text { (cm) }\end{array}$} & \multicolumn{2}{|c|}{$\begin{array}{c}\text { Material } \\
(\mathrm{kg})\end{array}$} & \multirow[t]{2}{*}{$\begin{array}{l}\text { Number } \\
\text { of Cells }\end{array}$} & \multicolumn{2}{|c|}{$\begin{array}{c}\text { Cell Layer Thickness } \\
(\mathrm{cm})\end{array}$} & \multirow[t]{2}{*}{ Basic Assembly Features } \\
\hline & & Uranium & Plastic & & Uranium & Plastic & \\
\hline 1 & 8.722 & 104.001 & - & 1 & 4.3610 & - & \multirow{18}{*}{$\begin{array}{c}\text { Unreflected, } \\
\text { Polyethylene Moderated, } \\
\text { Base Dimensions } 25.4 \mathrm{x} \\
25.4 \mathrm{~cm}\end{array}$} \\
\hline 2 & 9.545 & 99.660 & 0.7142 & 4 & 1.04144 & 0.30340 & \\
\hline 3 & 9.771 & 97.756 & 0.9384 & 3 & 1.36267 & 0.53176 & \\
\hline 4 & 9.898 & 95.929 & 1.1177 & 5 & 0.80032 & 0.37908 & \\
\hline 5 & 10.251 & 93.975 & 1.4073 & 7 & 0.56137 & 0.34174 & \\
\hline 6 & 10.401 & 92.089 & 1.6070 & 3 & 1.27965 & 0.90778 & \\
\hline 7 & 10.401 & 92.089 & 1.6090 & 6 & 0.63962 & 0.45432 & \\
\hline 8 & 10.424 & 92.055 & 1.6083 & 8 & 0.48077 & 0.34146 & \\
\hline 9 & 10.427 & 92.021 & 1.6183 & 4 & 0.96169 & 0.68328 & \\
\hline 10 & 11.689 & 76.687 & 3.0944 & 5 & 0.64219 & 1.05342 & \\
\hline 11 & 12.921 & 64.300 & 4.4132 & $\overline{8}$ & 0.33717 & 0.94076 & \\
\hline 12 & 13.007 & 61.444 & 4.5931 & 8 & 0.32268 & 0.98056 & \\
\hline 13 & 13.000 & 61.444 & 4.5931 & 4 & 0.64497 & 1.95998 & \\
\hline 14 & 13.165 & 61.444 & 4.6831 & 8 & 0.32277 & 1.00006 & \\
\hline 15 & 12.715 & 61.333 & 4.4733 & 4 & 0.64024 & 1.89830 & \\
\hline 16 & 12.758 & 61.333 & 4.4953 & 4 & 0.64050 & 1.90856 & \\
\hline 17 & 14.211 & 46.058 & 6.0803 & 6 & 0.32152 & 1.72550 & \\
\hline 18 & 14.328 & 46.058 & 6.1478 & 6 & 0.32156 & 1.74488 & \\
\hline 19 & 12.355 & 74.095 & - & 1 & 6.1775 & - & \multirow{8}{*}{$\begin{array}{c}\text { Unreflected, } \\
\text { Polyethylene Moderated, } \\
\text { Base Dimensions } 12.7 \mathrm{x} \\
25.4 \mathrm{~cm}\end{array}$} \\
\hline 20 & 15.730 & 71.721 & 1.1121 & 5 & 1.19605 & 0.75392 & \\
\hline 21 & 15.931 & 71.721 & 1.1699 & 5 & 1.19640 & 0.79334 & \\
\hline 22 & 16.132 & 71.721 & 1.2277 & 5 & 1.19675 & 0.83278 & \\
\hline 23 & 17.750 & 68.879 & 1.8390 & 4 & 1.43819 & 1.56098 & \\
\hline 24 & 17.915 & 68.879 & 1.8852 & 4 & 1.43886 & 1.60094 & \\
\hline 25 & 19.759 & 66.959 & 2.5234 & 5 & 1.11882 & 1.71404 & \\
\hline 26 & 19.964 & 66.959 & 2.5812 & 5 & 1.11935 & 1.75414 & \\
\hline 27 & 10.140 & 99.712 & 1.3717 & 4 & 1.04059 & 0.45372 & \multirow{5}{*}{$\begin{array}{c}\text { Unreflected, } \\
\text { Plexiglas Moderated, } \\
\text { Base Dimensions } 25.4 \mathrm{x} \\
25.4 \mathrm{~cm}\end{array}$} \\
\hline 28 & 10.996 & 95.921 & 2.2778 & 5 & 0.79891 & 0.60130 & \\
\hline 29 & 11.831 & 92.063 & 3.1701 & 6 & 0.63780 & 0.69628 & \\
\hline 30 & 14.514 & 76.692 & 6.1834 & 5 & 0.63719 & 1.62832 & \\
\hline 31 & 18.395 & 61.403 & 10.0897 & 8 & 0.31899 & 1.66134 & \\
\hline 32 & 11.908 & 109.189 & 3.881 & 6 & 0.75962 & 0.46534 & \multirow{3}{*}{$\begin{array}{c}\text { Unreflected, } \\
\text { Teflon Moderated, } \\
\text { Base Dimensions } 25.4 \mathrm{x} \\
25.4 \mathrm{~cm}\end{array}$} \\
\hline 33 & 14.709 & 114.991 & 6.963 & 6 & 0.80546 & 0.84060 & \\
\hline 34 & 17.770 & 120.709 & 10.460 & 6 & 0.84775 & 1.26612 & \\
\hline 35 & 5.362 & 31.771 & - & 1 & 2.681 & - & \multirow{9}{*}{$\begin{array}{c}\text { Polyethylene Reflected } \\
\text { and Moderated, Base } \\
\text { Dimensions } 12.7 \times 25.4 \\
\mathrm{~cm}\end{array}$} \\
\hline 36 & 6.307 & 30.664 & 0.3553 & 4 & 0.63837 & 0.30056 & \\
\hline 37 & 7.120 & 28.728 & 0.6716 & 6 & 0.40219 & 0.38222 & \\
\hline$\overline{38}$ & 7.351 & 28.646 & 0.7410 & 12 & 0.20074 & 0.21108 & \\
\hline 39 & 7.427 & 28.646 & 0.7640 & 12 & 0.19982 & 0.21666 & \\
\hline 40 & 7.242 & 28.641 & 0.7240 & 5 & 0.47836 & 0.49158 & \\
\hline 41 & 8.674 & 22.968 & 1.4141 & 6 & 0.32105 & 0.80356 & \\
\hline 42 & 8.809 & 22.968 & 1.4488 & 6 & 0.32165 & 0.82482 & \\
\hline 43 & 10.688 & 15.712 & 2.3558 & 11 & 0.12003 & 0.73160 & \\
\hline
\end{tabular}




\subsubsection{Multiple Unit Systems}

Six critical experiments were evaluated at the Russian experimental facility VNIITF in 1986. These experiments consisted of uranium metal in hemicylinders comprised of alternating materials. In 1962 and 1963 a set of detailed criticality experiments utilizing highly enriched uranium metal cylinders was conducted at the Oak Ridge Critical Experimental Facility (CEF). Critical arrays of uranium metal cylinders were constructed on a split table apparatus. The surface-to-surface spacing (STS) between the units were measured as a function of the number of units and the thickness of a paraffin reflector. These experiments are referred to as Tinkertoy experiments. HEU-MET-FAST-023 (Tinkertoy 1) provides a detailed description of the experimental configuration for 22 evaluated benchmark experiments developed from these experiments. HEU-MET-FAST026 (Tinkertoy 2) provides a detailed description of the experimental configuration for 32 evaluated benchmark experiments developed from these experiments. Table 60 contains the material composition for both experiments.

Table 60. Uranium Metal Composition $\left(18.76 \mathrm{~g} / \mathrm{cm}^{3}\right)$.

\begin{tabular}{|c|c|}
\hline Isotope & Wt \% \\
\hline $\mathrm{U}-234$ & 1.0 \\
\hline $\mathrm{U}-235$ & 93.2 \\
\hline $\mathrm{U}-236$ & 0.2 \\
\hline $\mathrm{U}-238$ & 5.6 \\
\hline
\end{tabular}

Details on the benchmark specifications used in validation model development are provided in the following paragraphs.

\subsection{Hemicylinders}

Six critical experiments involving hemicylinders of uranium metal were performed at the Russian facilities. Tables 61 and 62 provide the experimental descriptions and dimensions, respectively. 
Table 61. Description of Russian Experiments.

\begin{tabular}{|c|l||}
\hline Handbook I.D. & \multicolumn{1}{|c|}{ Experiment Description } \\
\hline HEU-MET-FAST-033 & $\begin{array}{l}\text { These two critical experiments, conducted at VNIITF, consisted of two hemicylinders } \\
\text { of alternating HEU, steel, and polyethylene disks separated by a gap that yielded a } \\
\text { critical configuration. The top hemicylinder rested on a steel diaphragm supported by } \\
\text { a Duralumin tripod and the movable bottom half rested in a Duralumin cone. }\end{array}$ \\
\hline HEU-MET-FAST-034 & $\begin{array}{l}\text { These three critical experiments, conducted at VNIITF, consisted of two } \\
\text { hemicylinders of alternating HEU, polyethylene, and either steel, titanium, or } \\
\text { aluminum disks separated by a gap that yielded a critical configuration. The top } \\
\text { hemicylinder rested on a steel diaphragm supported by a Duralumin tripod and the } \\
\text { movable bottom half rested in a Duralumin cone. }\end{array}$ \\
\hline HEU-MET-FAST-036 & $\begin{array}{l}\text { This critical experiment, conducted at VNIITF, consisted of two hemicylinders of } \\
\text { alternating HEU, polyethylene, and titanium disks, separated by a gap that yielded a } \\
\text { critical configuration, and reflected on all sides by polyethylene. The top } \\
\text { hemicylinder rested on a steel diaphragm and the movable bottom half rested on a } \\
\text { steel disk. }\end{array}$ \\
\hline
\end{tabular}

Table 62. Uranium Metal System Compositions and Dimensions.

\begin{tabular}{|c|c|c|c|c|c|c|}
\hline Handbook I.D. & $\begin{array}{c}\text { Core Material } \\
\text { Composition and } \\
\text { Density }(w t \%, g / c c)\end{array}$ & $\begin{array}{c}\text { Uranium Isotopic } \\
\text { Composition } \\
\text { (wt \%) }\end{array}$ & $\begin{array}{c}\text { Core } \\
\text { Material }\end{array}$ & $\begin{array}{l}\text { Core } \\
\text { Radius } \\
(\mathrm{cm})\end{array}$ & $\begin{array}{l}\text { Reflector } \\
\text { Material }\end{array}$ & $\begin{array}{c}\text { Reflector } \\
\text { Thickness (cm) }\end{array}$ \\
\hline HEU-MET-FAST-033 & $\begin{array}{c}\mathrm{U}=99.9896 \\
\mathrm{C}=.008 \\
\mathrm{Fe}=.009 \\
\mathrm{~W}=.0015 \\
\text { Density }=18.5892\end{array}$ & $\begin{array}{c}{ }^{234} U=1.18 \\
{ }^{235} U=95.95 \\
{ }^{238} U=2.84\end{array}$ & $\begin{array}{l}\text { Uranium } \\
\text { Metal with } \\
\mathrm{CH}_{2} \text { and } \\
\text { steel }\end{array}$ & 9.995 & None & $\mathrm{N} / \mathrm{A}$ \\
\hline HEU-MET-FAST-034 & $\begin{array}{c}\mathrm{U}=99.9815 \\
\mathrm{C}=.008 \\
\mathrm{Fe}=.009 \\
\mathrm{~W}=.021 \\
\text { Density }=18.5887\end{array}$ & $\begin{array}{l}{ }^{234} U=1.18 \\
{ }^{233} U=95.96 \\
{ }^{238} U=2.84\end{array}$ & $\begin{array}{c}\text { Uranium } \\
\text { Metal with } \\
\mathrm{CH}_{2} \text { and } \mathrm{Al} \text {, } \\
\mathrm{Ti} \text {, and steel }\end{array}$ & 9.995 & none & $\mathrm{N} / \mathrm{A}$ \\
\hline HEU-MET-FAST-036 & $\begin{array}{c}\mathrm{U}=99.9815 \\
\mathrm{C}=.008 \\
\mathrm{Fe}=.009 \\
\mathrm{~W}=.021 \\
\text { Density }=18.5887\end{array}$ & $\begin{array}{c}{ }^{234} U=1.1798 \\
{ }^{235} U=95.9603 \\
{ }^{238} U=2.8395\end{array}$ & $\begin{array}{c}\text { Uranium } \\
\text { Metal with } \\
\mathrm{CH}_{2} \text { and } \mathrm{Ti}\end{array}$ & 9.995 & $\mathrm{CH}_{2}$ & $\begin{array}{c}\text { Bottom }=9.94 \\
\text { Top }=9.94 \\
\text { Side }=9.393\end{array}$ \\
\hline
\end{tabular}




\subsection{Tinkertoy 1}

Arrays were built using cylinders of uranium metal with paraffin blocks set up as reflector walls. Two stainless steel rods passed through each cylinder and through the paraffin to support and space the units in the array. The benchmark dimensions are given in Table 63.

Table 63. Benchmark Array Dimensions for HEU-MET-FAST-023.

\begin{tabular}{|c|c|c|c|c|c|}
\hline Case \# & Array & $\begin{array}{c}\text { Cylinder } \\
\text { Diameter, D } \\
(\mathbf{c m})\end{array}$ & $\begin{array}{l}\text { Cylinder } \\
\text { Height, } \\
\text { H (cm) }\end{array}$ & $\begin{array}{l}\text { Cylinder } \\
\text { Spacing, } \\
\text { STS }(\mathbf{c m})\end{array}$ & $\begin{array}{l}\text { Reflector } \\
\text { Thickness, } \\
\text { RTH (cm) }\end{array}$ \\
\hline 2 & $2 \times 2 \times 2$ & 11.506 & 5.382 & 0.229 & 1.3 \\
\hline 3 & $2 \times 2 \times 2$ & 11.506 & 5.382 & 1.981 & $\overline{3.8}$ \\
\hline 4 & $2 \times 2 \times 2$ & 11.506 & 5.382 & 3.416 & 7.6 \\
\hline 5 & $2 \times 2 \times 2$ & 11.506 & 5.382 & 3.696 & 15.2 \\
\hline$\overline{6}$ & $3 \times 3 \times 3$ & 11.509 & 5.382 & 2.007 & 0.0 \\
\hline 7 & $3 \times 3 \times 3$ & 11.509 & 5.382 & 2.992 & 1.3 \\
\hline 8 & $3 \times 3 \times 3$ & 11.509 & 5.382 & 5.872 & 3.8 \\
\hline 9 & $3 \times 3 \times 3$ & 11.509 & 5.382 & 8.258 & 7.6 \\
\hline 10 & $3 \times 3 \times 3$ & 11.509 & 5.382 & 8.689 & 15.2 \\
\hline 12 & $2 \times 2 \times 2$ & 9.116 & 8.641 & 0.602 & 1.3 \\
\hline 13 & $2 \times 2 \times 2$ & 9.116 & 8.641 & 2.362 & 3.8 \\
\hline 14 & $2 \times 2 \times 2$ & 9.116 & 8.641 & 3.97 & 7.6 \\
\hline 15 & $2 \times 2 \times 2$ & 9.116 & 8.641 & 4.308 & 15.2 \\
\hline 16 & $3 \times 3 \times 3$ & 9.116 & 8.641 & 2.436 & 0.0 \\
\hline 17 & $3 \times 3 \times 3$ & 9.116 & 8.641 & 3.426 & 1.3 \\
\hline 18 & $3 \times 3 \times 3$ & 9.116 & 8.641 & 6.579 & 3.8 \\
\hline 19 & $3 \times 3 \times 3$ & 9.116 & 8.641 & 9.017 & 7.6 \\
\hline 20 & $3 \times 3 \times 3$ & 9.116 & 8.641 & 9.434 & 15.2 \\
\hline 21 & $4 \times 4 \times 4$ & 11.481 & 5.382 & 3.952 & 0.0 \\
\hline 22 & $4 \times 4 \times 4$ & 11.481 & 5.382 & 12.36 & 15.2 \\
\hline 28 & $3 \times 3 \times 3$ & 11.506 & 5.382 & 1.349 & 0.0 \\
\hline 29 & $3 \times 3 \times 5$ & 11.494 & 5.382 & 3.442 & 0.0 \\
\hline
\end{tabular}

Several arbitrary materials were used in the validation models. Arbitrary materials for the $0.88 \mathrm{~g} / \mathrm{cm}^{3}$ and $0.93 \mathrm{~g} / \mathrm{cm}^{3}$ paraffin were modeled as compounds $\left(\mathrm{C}_{25} \mathrm{H}_{52}\right)$ with the appropriate density $\left(0.88 \mathrm{~g} / \mathrm{cm}^{3}\right.$ for $1.3 \mathrm{~cm}$ thick paraffin and $0.93 \mathrm{~g} / \mathrm{cm}^{3}$ for all other paraffin thickness).

\footnotetext{
'Surface-to-Surface spacing of uranium units in vertical and horizontal directions.
} 


\subsection{Tinkertoy 2}

These experiments were performed using cylinders in four mass groups and with different height-to-diameter ratios. The experiments reported include cylinders with approximate masses of 15,20 , and $25 \mathrm{~kg}$. Table 64 lists the experimental array parameters.

Table 64. Benchmark Array Parameters for HEU-MET-FAST-026.

\begin{tabular}{|c|c|c|c|c|c|}
\hline Case \# & Array & $\begin{array}{c}\text { Cylinder } \\
\text { Diameter, D } \\
\text { (cm) }\end{array}$ & $\begin{array}{l}\text { Cylinder } \\
\text { Height, } \\
\text { H (cm) }\end{array}$ & $\begin{array}{l}\text { Cylinder } \\
\text { Spacing, } \\
\text { STS }^{\kappa}(\mathbf{c m})\end{array}$ & $\begin{array}{l}\text { Reflector } \\
\text { Thickness, } \\
\text { RTH (cm) }\end{array}$ \\
\hline 1 & $2 \times 2 \times 2$ & 11.494 & 8.077 & 0.902 & 0 \\
\hline 2 & $2 \times 2 \times 2$ & 11.494 & 8.077 & 1.905 & 1.3 \\
\hline 3 & $2 \times 2 \times 2$ & 11.494 & 8.077 & 4.961 & 3.8 \\
\hline 4 & $2 \times 2 \times 2$ & 11.494 & 8.077 & 7.391 & 7.6 \\
\hline 5 & $2 \times 2 \times 2$ & 11.494 & 8.077 & 7.823 & 15.2 \\
\hline 6 & $3 \times 3 \times 3$ & 11.490 & 8.077 & 4.204 & 0 \\
\hline 7 & $3 \times 3 \times 3$ & 11.490 & 8.077 & 5.677 & $1 . \overline{3}$ \\
\hline$\overline{8}$ & $3 \times 3 \times 3$ & 11.490 & 8.077 & 10.190 & 3.8 \\
\hline 9 & $3 \times 3 \times 3$ & 11.490 & 8.077 & 13.693 & 7.6 \\
\hline 10 & $3 \times 3 \times 3$ & 11.490 & 8.077 & 14.194 & 15.2 \\
\hline 11 & $2 \times 2 \times 2$ & 11.464 & 10.765 & 2.217 & 0 \\
\hline 12 & $2 \times 2 \times 2$ & 11.506 & 10.765 & 2.248 & 0 \\
\hline 13 & $2 \times 2 \times 2$ & 11.506 & 10.765 & 3.678 & 1.3 \\
\hline 14 & $2 \times 2 \times 2$ & 11.506 & 10.765 & 5.710 & 2.5 \\
\hline 15 & $2 \times 2 \times 2$ & 11.506 & 10.765 & 8.207 & 3.8 \\
\hline 16 & $2 \times 2 \times 2$ & 11.506 & 10.765 & 11.509 & 7.6 \\
\hline 17 & $2 \times 2 \times 2$ & 11.506 & 10.765 & 11.986 & 15.2 \\
\hline 18 & $3 \times 3 \times 3$ & 11.484 & 10.765 & 6.363 & 0 \\
\hline 19 & $3 \times 3 \times 3$ & 11.484 & 10.765 & 8.574 & 1.3 \\
\hline 20 & $3 \times 3 \times 3$ & 11.484 & 10.765 & 14.764 & 3.8 \\
\hline 21 & $3 \times 3 \times 3$ & 11.484 & 10.765 & 18.720 & 7.6 \\
\hline 22 & $3 \times 3 \times 3$ & 11.484 & 10.765 & 19.147 & 15.2 \\
\hline 23 & $2 \times 2 \times 2$ & 11.509 & 13.459 & 3.543 & 0 \\
\hline 24 & $2 \times 2 \times 2$ & 11.509 & 13.459 & 5.423 & 1.3 \\
\hline 25 & $2 \times 2 \times 2$ & 11.509 & 13.459 & 11.532 & 3.8 \\
\hline 26 & $2 \times 2 \times 2$ & 11.509 & 13.459 & 15.697 & 7.6 \\
\hline 27 & $2 \times 2 \times 2$ & 11.509 & 13.459 & 16.378 & 15.2 \\
\hline 28 & $3 \times 3 \times 3$ & 11.486 & 13.459 & 8.494 & 0 \\
\hline 29 & $3 \times 3 \times 3$ & 11.486 & 13.459 & 11.323 & 1.3 \\
\hline 30 & $3 \times 3 \times 3$ & 11.486 & 13.459 & 19.606 & 3.8 \\
\hline 31 & $3 \times 3 \times 3$ & 11.486 & 13.459 & 24.498 & 7.6 \\
\hline 32 & $3 \times 3 \times 3$ & 11.486 & 13.459 & 24.991 & 15.2 \\
\hline
\end{tabular}

$\mathrm{K}$ Surface-to-Surface spacing of uranium units in vertical and horizontal directions. 


\subsubsection{Bias and Uncertainty}

The distribution of the data for the fast uranium experiments was determined to be nonnormal. Figure 3 provides a plot of the calculated $k_{\text {eff }}$ values versus the average energy groups.

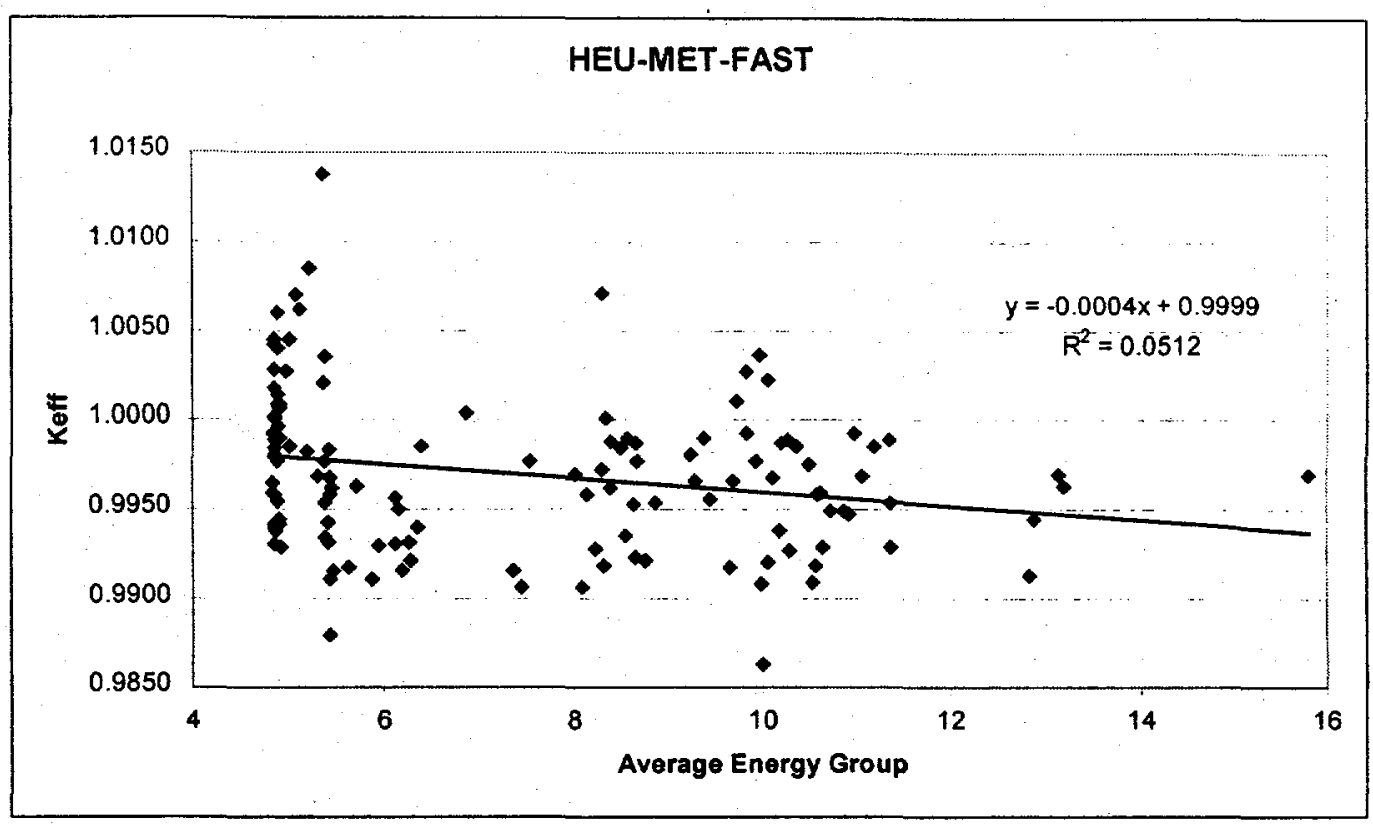

Figure 3. $K_{\mathrm{efr}}$ versus Average Energy Group.

A non-parametric upper subcritical limit was calculated due to the non-normal distribution of the data and the poor fit of the trendline to the data series $\left(R^{2}=0.0512\right)$. An attempt to fit this data to the curves specified in Reference 4 also failed. With a data set of 128 , there is a $99.8 \%$ confidence that $95 \%$ of the data lies above the smallest value (see Equation 2 on page 33).

The non-parametric margin for this level of confidence is 0.0 (see section 2.9.1 of Reference 4). Therefore, the upper subcritical limit can be calculated from Equation 3 on page 34 .

$$
=0.9863-\sqrt{(0.0012)^{2}+(0.0010)^{2}}-0.0=0.9847
$$

The upper subcritical limit for the uranium metal systems is 0.984 . 


\subsubsection{Limitations}

These results were obtained using MCNP version 4B running on the WSMS DEC Alpha Workstation. They are applicable to bare and reflected highly enriched uranium metal systems with the average energy of the fissioning neutrons from $2.0 \mathrm{eV}$ to $1.5 \mathrm{MeV}$. The results cover an intermediate to fast average fission energy range and are not applicable to systems containing significant interstitial moderation (i.e., H/U-235 ratio $\neq 0$ ) or those for which the average energy group is in the thermal range.

As can be seen in the tables in this section, the majority of the evaluated experiments have U-238 content near $5 \%$. A subcritical margin as low as 0.02 may be appropriate for those experiments. Use of this bias with cases having U-238 significantly different from $5 \%$ requires use of the area of applicability margin $(\mathrm{AOA})^{4}$. 


\subsection{Research Reactor Fuel}

\subsection{Area of Applicability}

This section presents the MCNP validation analysis for the SPERT-D fuel element experiment (HEU-MET-THERM-006 ${ }^{5}$ ). It is important to note that the plates and water gaps in the SPERT-D fuel element were modeled explicitly in all experiments. The results of this analysis present a weighted (including statistical and experimental uncertainties), single-sided lower tolerance limit. The MCNP user should employ the F-4 flux tally to obtain the average energy to assure that the evaluated system is contained within the applicable neutron spectrum. Key areas of applicability for these experiments include:

1. Fuel:

2. Moderation:

3. Enrichment:

4. Moderating Material:

5. Reflector Material:

6. Geometry:

7. Neutron Spectrum ${ }^{\text {: }}$

MTR type fuel (uranium-aluminum alloy)

$\mathrm{H} / \mathrm{U}-235 \sim 140$ (fully flooded fuel assembly)

High (93.5 wt \% U-235)

Water

Water

Lattices of SPERT-D fuel elements

Thermal; $0.069-0.146 \mathrm{eV}$

AEG: (18 energy bin structure)12.89-13.31

\subsubsection{System Description}

Twenty-three critical experiments involving lattices of SPERT-D fuel elements were performed at the Oak Ridge National Laboratory (ORNL). The SPERT-D fuel element consists of a 3-inch square aluminum container, 0.062 inches thick and 27.625 inches long. The container holds a maximum of 22 fuel plates; each plate containing an average of 13.93 grams of U-235. The fuel is a uranium-aluminum alloy with $23.8 \mathrm{wt} \%$ uranium and the isotopic mixture contains $93.17 \mathrm{wt} \%$ of U-235. Fourteen of the twenty-three experiments were deemed acceptable for validation purposes.

\subsubsection{Bias and Uncertainty}

The Shapiro-Wilk ${ }^{4}$ test is used to determine if the distribution is normal. This test assumes that the data are normally distributed and calculates the test statistic for normality. If the value of the test statistic falls under a critical value, the distribution of the data is not normal. We applied the Shapiro-Wilk test to 13 out of the 14 data points. For these experiments, the data is determined to be normal from the evaluation of this test. One data point was considered an outliner due to its magnitude and therefore was excluded in the normalcy test calculation. Figure 4 provides a plot of the $k_{\text {eff }}$ values versus the average energy group.

\footnotetext{
${ }^{L}$ The neutron spectrum represents the average energy of the neutrons causing fission.
} 
HEU-MET-THERM

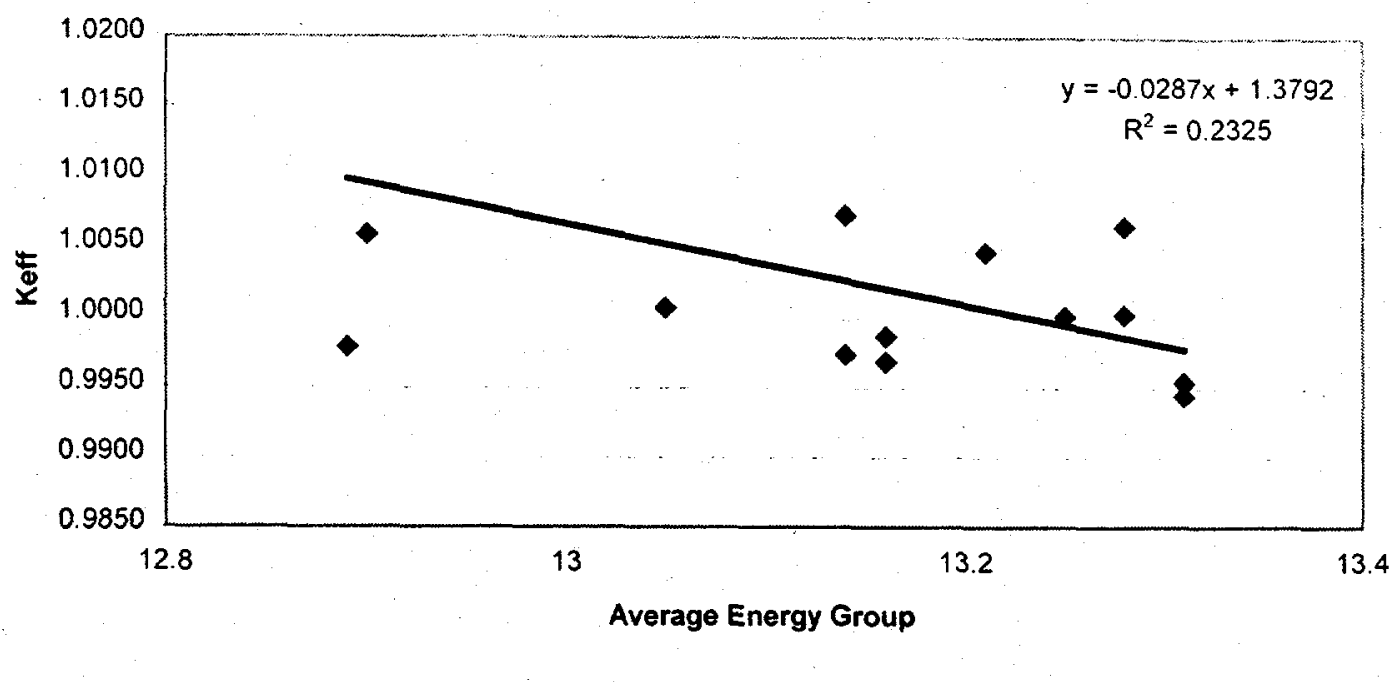

Figure 4. $K_{\text {eff }}$ versus Average Energy Group.

Due to the undesirable fit of the data to the independent variable, a lower tolerance limit was determined for the data set using Equation 1 on page 13. For the lower tolerance limit calculation, all 14 data points were taken into account.

A single-sided lower tolerance limit of 0.976 is calculated for the 14 thermal uranium experiments.

Table 65 lists the results from the statistical analysis of the 14 data points.

Table 65. Results from Statistical Analysis.

\begin{tabular}{|l|c|}
\hline & $\begin{array}{c}\text { All 14 Experiments } \\
\text { (WEIGHTED DATA) }\end{array}$ \\
\hline One-sided Lower Tolerance Factor (U) & 2.614 \\
\hline Sqrt of Pooled Variance (Sp) & $9.901 \mathrm{E}-03$ \\
\hline Variance About the Mean $\left(\mathbf{S}^{2}\right)$ & $7.989 \mathrm{E}-05$ \\
\hline Average Uncertainty $\left(\sigma^{2}\right)$ & $1.814 \mathrm{E}-05$ \\
\hline Average $\mathrm{k}_{\text {off }}$ & 1.0026 \\
\hline Lower Tolerance Limit & 0.976 \\
\hline
\end{tabular}




\subsubsection{Limitations}

Although the parameters of the benchmark experiments do not completely envelop MIT type fuel, the applicability parameters are considered sufficient for analysis of MIT type fuel in flooded conditions. Use of this bias with cases extended outside the area of applicability listed in section 5.2.1 requires the use of an area of applicability margin (AOA). A subcritical margin of 0.05 is to be used unless there is justification to use a smaller safety margin. 


\subsection{Uranium Solution ${ }^{7}$}

\subsubsection{Area of Applicability}

This section presents the MCNP validation analysis for reflected and unreflected highly enriched uranium solutions. The result from this analysis is a lower tolerance limit for the MCNP-4B code system with the ENDF/B-V cross section library. The MCNP user should employ the F-4 flux tally to obtain the average energy to assure that the evaluated system is contained within the applicable neutron spectrum. Key areas of applicability for these experiments include:

1. Fuel:

2. Moderation:

3. Enrichment:

4. Moderating Material:

5. Reflecting Material:

6. Geometry:

7. Neutron Spectrum ${ }^{N}$ :
Highly enriched uranium solutions

H/U-235: 50-1300

High, 80-92.3 wt \% U-235

Water

Concrete, Plexiglas, Water or None (with

$\mathrm{Al}$ or Steel Containers or Sleeves)

Single Unit Spheres, Cylinders, and Arrays

of Cylinders

Thermal; $0.051-0.68 \mathrm{eV}$

AEG: 21.47-24.99

\subsubsection{System Description}

In support of this validation, seventy-four critical uranyl nitrate experiments involving bare and concrete or Plexiglas reflected single cylinders or arrays of cylinders were extracted from the International Handbook of Evaluated Criticality Benchmark Experiments. In addition, eleven critical uranium oxyflouride experiments involving single water reflected spheres were extracted from draft reports issued in Reference 5.

\subsubsection{Single Unit Unreflected Cylinders of Uranyl Nitrate}

Ten of the experiments utilized single bare cylinders of uranyl nitrate. A summary of the experimental parameters from Reference 5 is provided in Table 66. The isotopic composition of the uranium used in the experiments is provided in Table 67.

\footnotetext{
${ }^{\mathrm{M}}$ See limitations (Sect. 5.3.4)

${ }^{N}$ The neutron spectrum represents the average energy of the neutrons causing fission.
} 
Table 66. Reported Single Unit Cylinder Parameters (HEU-SOL-THERM-00155).

\begin{tabular}{|c|c|c|c|c|c|c|}
\hline $\begin{array}{c}\text { Experiment } \\
\text { Descriptor }\end{array}$ & $\begin{array}{c}\text { Tank } \\
\text { Composition }\end{array}$ & $\begin{array}{c}\text { Critical } \\
\text { Height } \\
(\mathbf{c m})\end{array}$ & $\begin{array}{c}\text { Inner } \\
\text { Diameter } \\
(\mathbf{c m})\end{array}$ & $\begin{array}{c}\text { Uranium } \\
\text { Concentration } \\
(\mathbf{g} / \mathbf{l})\end{array}$ & $\begin{array}{c}\text { Molarity (Excess } \\
\text { Nitric Acid - } \\
\text { moles/L) }\end{array}$ & $\begin{array}{c}\text { Solution } \\
\text { Density } \\
\left(\mathbf{g} / \mathbf{c m}^{3}\right)\end{array}$ \\
\hline $\mathbf{1}$ & $304 \mathrm{SS}$ & 31.20 & 27.92 & 145.68 & 0.294 & 1.2038 \\
\hline $\mathbf{2}$ & $304 \mathrm{SS}$ & 28.93 & 27.92 & 346.73 & 0.542 & 1.4800 \\
\hline $\mathbf{3}$ & $6061 \mathrm{Al}$ & 33.55 & 28.01 & 142.92 & 0.283 & 1.2007 \\
\hline $\mathbf{4}$ & $6061 \mathrm{Al}$ & 30.91 & 28.01 & 357.71 & 0.549 & 1.4951 \\
\hline $\mathbf{5}$ & $6061 \mathrm{Al}$ & 39.48 & 33.01 & 54.89 & 0.105 & 1.0758 \\
\hline $\mathbf{6}$ & $6061 \mathrm{Al}$ & 36.67 & 33.01 & 59.65 & 0.114 & 1.0825 \\
\hline $\mathbf{7}$ & $6061 \mathrm{Al}$ & 23.96 & 33.01 & 137.40 & 0.287 & 1.1923 \\
\hline $\mathbf{8}$ & $6061 \mathrm{Al}$ & 23.67 & 33.01 & 145.68 & 0.294 & 1.2038 \\
\hline $\mathbf{9}$ & $6061 \mathrm{Al}$ & 22.53 & 33.01 & 357.71 & 0.549 & 1.4951 \\
\hline $\mathbf{1 0}$ & $6061 \mathrm{Al}$ & 20.48 & 50.69 & 63.95 & 0.111 & 1.0883 \\
\hline
\end{tabular}

Table 67. Uranium Isotopic Composition.

\begin{tabular}{|c|c|}
\hline Isotope & Wt \% \\
\hline${ }^{234} \mathrm{U}$ & 1.022 \\
\hline${ }^{235} \mathrm{U}$ & 93.172 \\
\hline${ }^{236} \mathrm{U}$ & 0.434 \\
\hline${ }^{238} \mathrm{U}$ & 5.372 \\
\hline
\end{tabular}

\subsubsection{Single Unit Concrete-Reflected Cylinders of Uranyl Nitrate}

Fourteen of the experiments utilized single concrete-reflected cylinders of uranyl nitrate. A summary of the experimental parameters from Reference 5 is provided in Table 68 . The isotopic composition of the uranium present matches the composition of that found in Table 67. The composition of the concrete used in the experimental models is provided in Table 69. Cylinder position was varied within a $\sim 10$-inch-thick concrete box. The inside dimensions of this box formed a rough cube $(122 \mathrm{~cm}$ per side).

Table 68. Reported Single Unit Cylinder Parameters (HEU-SOL-THERM-002 ${ }^{5}$ ).

\begin{tabular}{|c|c|c|c|c|c|c|}
\hline $\begin{array}{c}\text { Experiment } \\
\text { Descriptor }\end{array}$ & $\begin{array}{c}\text { Tank } \\
\text { Composition }\end{array}$ & $\begin{array}{c}\text { Critical } \\
\text { Height } \\
(\mathbf{c m})\end{array}$ & $\begin{array}{c}\text { Inner } \\
\text { Diameter } \\
(\mathbf{c m})\end{array}$ & $\begin{array}{c}\text { Uranium } \\
\text { Concentration } \\
(\mathrm{g} / \mathbf{l})\end{array}$ & $\begin{array}{c}\text { Molarity } \\
(\text { Excess Nitric } \\
\text { Acid - moles/L) }\end{array}$ & $\begin{array}{c}\text { Solution } \\
\text { Density } \\
\left(\mathbf{g} / \mathrm{cm}^{3}\right)\end{array}$ \\
\hline $\mathbf{1}$ & $304 \mathrm{SS}$ & 29.79 & 27.92 & 144.38 & 0.272 & 1.2023 \\
\hline $\mathbf{2}$ & $304 \mathrm{SS}$ & 24.19 & 27.92 & 144.38 & 0.272 & 1.2023 \\
\hline 3 & $304 \mathrm{SS}$ & 27.23 & 27.92 & 334.77 & 0.521 & 1.4636 \\
\hline 4 & $304 \mathrm{SS}$ & 21.79 & 27.92 & 334.77 & 0.521 & 1.4636 \\
\hline 5 & $6061 \mathrm{Al}$ & 31.37 & 28.01 & 144.38 & 0.272 & 1.2023 \\
\hline
\end{tabular}




\begin{tabular}{||l|l|l|l|l|l|l|}
\hline $\mathbf{6}$ & $6061 \mathrm{Al}$ & 24.70 & 28.01 & 144.38 & 0.272 & 1.2023 \\
\hline $\mathbf{7}$ & $6061 \mathrm{Al}$ & 28.60 & 28.01 & 334.77 & 0.521 & 1.4636 \\
\hline $\mathbf{8}$ & $6061 \mathrm{Al}$ & 22.33 & 28.01 & 334.77 & 0.521 & 1.4636 \\
\hline $\mathbf{9}$ & $6061 \mathrm{Al}$ & 34.10 & 33.01 & 59.65 & 0.114 & 1.0825 \\
\hline 10 & $6061 \mathrm{Al}$ & 27.27 & 33.01 & 59.65 & 0.114 & 1.0825 \\
\hline 11 & $6061 \mathrm{Al}$ & 22.85 & 33.01 & 144.38 & 0.272 & 1.2023 \\
\hline 12 & $6061 \mathrm{Al}$ & 18.24 & 33.01 & 144.38 & 0.272 & 1.2023 \\
\hline 13 & $6061 \mathrm{Al}$ & 21.50 & 33.01 & 334.77 & 0.521 & 1.4636 \\
\hline 14 & $6061 \mathrm{Al}$ & 16.78 & 33.01 & 334.77 & 0.521 & 1.4636 \\
\hline
\end{tabular}

Table 69. Concrete Composition $\left(\rho=2.321 \mathrm{~g} / \mathrm{cm}^{3}\right)$.

\begin{tabular}{|c|c|}
\hline Isotope & Wt \% \\
\hline $\mathrm{H}$ & 0.75 \\
\hline $\mathrm{K}$ & 1.37 \\
\hline $\mathrm{Si}$ & 15.50 \\
\hline $\mathrm{S}$ & 0.19 \\
\hline $\mathrm{Na}$ & 0.63 \\
\hline $\mathrm{Ti}$ & 0.1 \\
\hline $\mathrm{Ca}$ & 23.0 \\
\hline $\mathrm{C}$ & 5.52 \\
\hline $\mathrm{N}$ & 0.02 \\
\hline $\mathrm{O}$ & 48.49 \\
\hline $\mathrm{Mg}$ & 1.25 \\
\hline $\mathrm{Al}$ & 2.17 \\
\hline $\mathrm{Fe}$ & 1.01 \\
\hline
\end{tabular}

\subsubsection{Single Unit Plexiglas-Reflected Cylinders of Uranyl Nitrate}

Nineteen of the experiments utilized single Plexiglas-reflected cylinders of uranyl nitrate. A summary of the experimental parameters from Reference 5 is provided in Table 70. The isotopic composition of the uranium present matches the composition of that found in Table 67. The composition of the Plexiglas used in the experimental models is

provided in Table 71. Cylinder position was varied within $\sim 8$-inch-thick Plexiglas box. The inside dimensions of this box formed a rough cube $(122 \mathrm{~cm}$ per side). 
Table 70. Reported Single Unit Cylinder Parameters (HEU-SOL-THERM-0035).

\begin{tabular}{|c|c|c|c|c|c|c|}
\hline $\begin{array}{c}\text { Experiment } \\
\text { Descriptor }\end{array}$ & $\begin{array}{c}\text { Tank } \\
\text { Composition }\end{array}$ & $\begin{array}{c}\text { Critical } \\
\text { Height } \\
(\mathbf{c m})\end{array}$ & $\begin{array}{c}\text { Inner } \\
\text { Diameter } \\
(\mathbf{c m})\end{array}$ & $\begin{array}{c}\text { Uranium } \\
\text { Concentration } \\
(\mathbf{g} / \mathbf{l})\end{array}$ & $\begin{array}{c}\text { Molarity } \\
\text { (Excess Nitric } \\
\text { Acid - moles/L) }\end{array}$ & $\begin{array}{c}\text { Solution } \\
\text { Density } \\
\left(\mathbf{g} / \mathrm{cm}^{3}\right)\end{array}$ \\
\hline $\mathbf{I}$ & $304 \mathrm{SS}$ & 50.52 & 27.93 & 60.32 & 0.113 & 1.0837 \\
\hline $\mathbf{2}$ & $304 \mathrm{SS}$ & 67.48 & 27.93 & 60.32 & 0.113 & 1.0837 \\
\hline $\mathbf{3}$ & $304 \mathrm{SS}$ & 29.71 & 27.92 & 147.66 & 0.271 & 1.2069 \\
\hline $\mathbf{4}$ & $304 \mathrm{SS}$ & 25.03 & 27.92 & 147.66 & 0.271 & 1.2069 \\
\hline $\mathbf{5}$ & $304 \mathrm{SS}$ & 27.60 & 27.92 & 345.33 & 0.534 & 1.4779 \\
\hline $\mathbf{6}$ & $304 \mathrm{SS}$ & 22.75 & 27.92 & 345.33 & 0.534 & 1.4779 \\
\hline $\mathbf{7}$ & $6061 \mathrm{Al}$ & 51.67 & 27.88 & 60.32 & 0.133 & 1.0837 \\
\hline $\mathbf{8}$ & $6061 \mathrm{Al}$ & 31.26 & 28.01 & 147.66 & 0.271 & 1.2069 \\
\hline $\mathbf{9}$ & $6061 \mathrm{Al}$ & 25.26 & 28.01 & 147.66 & 0.271 & 1.2069 \\
\hline $\mathbf{1 0}$ & $6061 \mathrm{Al}$ & 28.84 & 28.01 & 345.33 & 0.534 & 1.4779 \\
\hline $\mathbf{1 1}$ & $6061 \mathrm{Al}$ & 22.87 & 28.01 & 345.33 & 0.534 & 1.4779 \\
\hline $\mathbf{1 2}$ & $6061 \mathrm{Al}$ & 34.33 & 33.01 & 60.32 & 0.113 & 1.0837 \\
\hline $\mathbf{1 3}$ & $6061 \mathrm{Al}$ & 27.70 & 33.01 & 60.32 & 0.113 & 1.0837 \\
\hline $\mathbf{1 4}$ & $6061 \mathrm{Al}$ & 31.75 & 33.01 & 60.32 & 0.113 & 1.0837 \\
\hline $\mathbf{1 5}$ & $6061 \mathrm{Al}$ & 25.10 & 33.01 & 66.33 & 0.120 & 1.0920 \\
\hline $\mathbf{1 6}$ & $6061 \mathrm{Al}$ & 22.78 & 33.01 & 147.66 & 0.271 & 1.2069 \\
\hline 17 & $6061 \mathrm{Al}$ & 18.49 & 33.01 & 147.66 & 0.271 & 1.2069 \\
\hline $\mathbf{1 8}$ & $6061 \mathrm{Al}$ & 21.67 & 33.01 & 345.33 & 0.534 & 1.4779 \\
\hline $\mathbf{1 9}$ & $6061 \mathrm{Al}$ & 17.20 & 33.01 & 345.33 & 0.534 & 1.4779 \\
\hline
\end{tabular}

Table 71. Plexiglas Composition, wt $\%$ ( $\rho$ side panels $=1.1863 \mathrm{~g} / \mathrm{cm}^{3}$, $\rho$ top and bottom panels $=1.286 \mathrm{~g} / \mathrm{cm}^{3}$ ).

\begin{tabular}{||c|c|c|}
\hline Element & $\begin{array}{c}\text { Top and Bottom Panels } \\
\text { (Fire Retardant) }\end{array}$ & $\begin{array}{c}\text { Four Side Panels } \\
\text { (Non-Fire Retardant) }\end{array}$ \\
\hline Hydrogen & 7.18 & 8.03 \\
\hline Carbon & 52.68 & 59.72 \\
\hline Nitrogen & 0.10 & Not measured \\
\hline Oxygen & 29.4 & 32.14 \\
\hline Phosphorous & 1.54 & Not measured \\
\hline Chlorine & 1.63 & Not measured \\
\hline Bromine & 6.5 & Not measured \\
\hline Ash & 0.71 & Not measured \\
\hline
\end{tabular}




\subsubsection{Concrete-Reflected Arrays of Uranyl Nitrate Cylinders}

Seventeen of the experiments utilized concrete-reflected arrays of uranyl cylinders. A summary of the experimental parameters from Reference 5 is provided in Table 72 . Arrays of various sizes were placed with a $\sim 10$ inch-thick concrete box that was used for the experiments. The inside dimensions of this box formed a rough cube $(122 \mathrm{~cm}$ per side). The isotopic composition of the uranium matches the composition contained in Table 67. The composition of the concrete used in the experimental models is provided above in Table 69.

Table 72. Reported Concrete-Reflected Array Parameters (HEU-SOL-THERM-0075).

\begin{tabular}{||c|c|c|c|c|c|c||}
\hline $\begin{array}{c}\text { Experiment } \\
\text { Descriptor } \\
\text { (array size) }\end{array}$ & $\begin{array}{c}\text { Tank } \\
\text { Composition }\end{array}$ & $\begin{array}{c}\text { Critical } \\
\text { Height } \\
(\mathbf{c m})\end{array}$ & $\begin{array}{c}\text { Inner } \\
\text { Diameter } \\
(\mathbf{c m})\end{array}$ & $\begin{array}{c}\text { Uranium } \\
\text { Concentration } \\
(\mathrm{g} / \mathbf{l})\end{array}$ & $\begin{array}{c}\text { Molarity } \\
\text { (Excess Nitric } \\
\text { Acid - moles/L) }\end{array}$ & $\begin{array}{c}\text { Solution } \\
\text { Density } \\
\left(\mathrm{g} / \mathrm{cm}^{3}\right)\end{array}$ \\
\hline $1(4 \times 4 \times 1)$ & $6061 \mathrm{Al}$ & 28.63 & 21.12 & 67.28 & 0.128 & 1.0934 \\
\hline $2(4 \times 4 \times 1)-$ & $6061 \mathrm{Al}$ & 17.24 & 21.12 & 369.96 & 0.598 & 1.5120 \\
\hline $3(4 \times 4 \times 1)$ & $6061 \mathrm{Al}$ & 27.15 & 21.12 & 67.28 & 0.128 & 1.0934 \\
\hline $4(4 \times 4 \times 1)$ & $6061 \mathrm{Al}$ & 17.13 & 21.12 & 364.11 & 0.584 & 1.5054 \\
\hline $5(2 \times 2 \times 1)$ & $6061 \mathrm{Al}$ & 60.70 & 21.12 & 76.09 & 0.137 & 1.1057 \\
\hline $6(2 \times 2 \times 1)$ & $6061 \mathrm{Al}$ & 29.49 & 21.12 & 360.37 & 0.585 & 1.4995 \\
\hline $7(2 \times 2 \times 1)$ & $6061 \mathrm{Al}$ & 62.34 & 21.12 & 76.09 & 0.137 & 1.1057 \\
\hline $8(2 \times 2 \times 1)$ & $6061 \mathrm{Al}$ & 31.11 & 21.12 & 364.11 & 0.584 & 1.5054 \\
\hline $9(2 \times 2 \times 1)$ & $6061 \mathrm{Al}$ & 57.88 & 21.12 & 80.72 & 0.143 & 1.1122 \\
\hline $10(4 \times 4 \times 1)$ & $6061 \mathrm{Al}$ & 57.34 & 16.12 & 83.49 & 0.151 & 1.1164 \\
\hline $11(4 \times 4 \times 1)$ & $6061 \mathrm{Al}$ & 32.32 & 16.12 & 360.37 & 0.585 & 1.4995 \\
\hline $12(4 \times 4 \times 1)$ & $6061 \mathrm{Al}$ & 51.21 & 16.12 & 83.49 & 0.151 & 1.1164 \\
\hline $13(4 \times 4 \times 1)$ & $6061 \mathrm{Al}$ & 31.82 & 16.12 & 359.55 & 0.578 & 1.4984 \\
\hline $14(2 \times 4 \times 1)$ & $6061 \mathrm{Al}$ & 51.45 & 16.12 & 359.55 & 0.578 & 1.4984 \\
\hline $15(2 \times 3 \times 1)$ & $6061 \mathrm{Al}$ & 65.49 & 16.12 & 359.55 & 0.578 & 1.4984 \\
\hline $16(2 \times 2 \times 1)$ & $6061 \mathrm{Al}$ & 101.45 & 16.12 & 359.55 & 0.578 & 1.4984 \\
\hline $17(2 \times 2 \times 1)$ & $6061 \mathrm{Al}$ & 104.04 & 16.12 & 359.55 & 0.578 & 1.4984 \\
\hline
\end{tabular}

\subsubsection{Plexiglas-Reflected Arrays of Uranyl Nitrate Cylinders}

Fourteen of the experiments utilized single Plexiglas-reflected cylinders of uranyl nitrate. A summary of the experimental parameters from Reference 5 is provided in Table 73 . The isotopic composition of the uranium matches the composition of that contained in Table 67. The composition of the Plexiglas used in the experimental models is identical to that provided in Table 71 . Arrays of various sizes were placed with a $\sim 8$ inch-thick Plexiglas box that was used for the experiments. The inside dimensions of this box formed a rough cube $(122 \mathrm{~cm}$ per side). 
Table 73. Reported Plexiglas-Reflected Array Parameters (HEU-SOL-THERM-008).

\begin{tabular}{|c|c|c|c|c|c|c||}
\hline $\begin{array}{c}\text { Experiment } \\
\text { Descriptor } \\
\text { (array size) }\end{array}$ & $\begin{array}{c}\text { Tank } \\
\text { Composition }\end{array}$ & $\begin{array}{c}\text { Critical } \\
\text { Height } \\
(\mathbf{c m})\end{array}$ & $\begin{array}{c}\text { Inner } \\
\text { Diameter } \\
(\mathbf{c m})\end{array}$ & $\begin{array}{c}\text { Uranium } \\
\text { Concentration } \\
(\mathbf{g} / \mathbf{l})\end{array}$ & $\begin{array}{c}\text { Molarity } \\
\text { (Excess Nitric } \\
\text { Acid - moles/L) }\end{array}$ & $\begin{array}{c}\text { Solution } \\
\text { Density } \\
\left(\mathbf{g} / \mathbf{c m}^{3}\right)\end{array}$ \\
\hline $1(4 \times 4 \times 1)$ & $6061 \mathrm{Al}$ & 34.82 & 21.12 & 60.32 & 0.113 & 1.0837 \\
\hline $2(4 \times 4 \times 1)$ & $6061 \mathrm{Al}$ & 19.27 & 21.12 & 355.94 & 0.494 & 1.4925 \\
\hline $3(4 \times 4 \times 1)$ & $6061 \mathrm{Al}$ & 31.76 & 21.12 & 60.32 & 0.113 & 1.0837 \\
\hline $4(4 \times 4 \times 1)$ & $6061 \mathrm{Al}$ & 18.82 & 21.12 & 355.94 & 0.494 & 1.4925 \\
\hline $5(2 \times 2 \times 1)$ & $6061 \mathrm{Al}$ & 110.20 & 21.12 & 60.32 & 0.113 & 1.0837 \\
\hline $6(2 \times 2 \times 1)$ & $6061 \mathrm{Al}$ & 31.93 & 21.12 & 355.94 & 0.494 & 1.4925 \\
\hline $7(2 \times 2 \times 1)$ & $6061 \mathrm{Al}$ & 102.29 & 21.12 & 60.32 & 0.113 & 1.0837 \\
\hline $8(2 \times 2 \times 1)$ & $6061 \mathrm{Al}$ & 33.20 & 21.12 & 355.94 & 0.494 & 1.4925 \\
\hline $9(4 \times 4 \times 1)$ & $6061 \mathrm{Al}$ & 105.85 & 16.12 & 60.32 & 0.113 & 1.0837 \\
\hline $10(4 \times 4 \times 1)$ & $6061 \mathrm{Al}$ & 38.10 & 16.12 & 355.94 & 0.494 & 1.4925 \\
\hline $11(4 \times 4 \times 1)$ & $6061 \mathrm{Al}$ & 78.40 & 16.12 & 60.32 & 0.113 & 1.0837 \\
\hline $12(4 \times 4 \times 1)$ & $6061 \mathrm{Al}$ & 35.56 & 16.12 & 355.94 & 0.494 & 1.4925 \\
\hline $13(2 \times 3 \times 1)$ & $6061 \mathrm{Al}$ & 95.20 & 16.12 & 355.94 & 0.494 & 1.4925 \\
\hline $14(2 \times 3 \times 1)$ & $6061 \mathrm{Al}$ & 89.78 & 16.12 & 355.94 & 0.494 & 1.4925 \\
\hline
\end{tabular}

\subsubsection{Uranium Oxyfluoride $\left(\mathrm{UO}_{2} \mathrm{~F}_{2}\right)$ Solution Experiments}

These experiments utilized single water-reflected spheres of uranium oxyfluoride. A summary of the experimental parameters is provided in Table 74. The isotopic composition of the uranium is provided in Table 75 . For all cases the spheres were reflected by at least $15 \mathrm{~cm}$ of water.

Table 74. Reported $\mathrm{UO}_{2} \mathrm{~F}_{2}$ Experiment Parameters.

\begin{tabular}{|c|c|c|c|c|c|}
\hline Descriptor & $\begin{array}{c}\text { Solution } \\
\text { Density }(\mathbf{g} / \mathbf{c c})\end{array}$ & $\begin{array}{c}\text { Uranium } \\
\text { Concentration } \\
(\mathbf{g} / \mathbf{l})\end{array}$ & $\mathbf{H} / \mathbf{U}-235$ & Radius (cm) & $\begin{array}{c}\text { 235 U Mass } \\
(\mathbf{k g})\end{array}$ \\
\hline HEU-SOL-THERM-0095 & & & & & \\
\hline 1 & 1.79495 & 696 & 36 & 11.5177 & 4.15 \\
\hline 2 & 1.62055 & 543 & 47 & 11.4695 & 3.20 \\
\hline 3 & 1.40045 & 349 & 76 & 11.5177 & 2.08 \\
\hline 4 & 1.23955 & 213 & 126 & 11.8442 & 1.37 \\
\hline HEU-SOL-THERM-0115 & & & & & \\
\hline 1 & 1.0597 & 53 & 523 & 15.9572 & 0.84 \\
\hline 2 & 1.0596 & 52 & 533 & 15.9569 & 0.83 \\
\hline HEU-SOL-THERM-0125 & & & & & \\
\hline 1 & 1.0265 & 22 & 1272 & 27.9244 & 1.87 \\
\hline HEU-SOL-THERM-0105 & & & & & \\
\hline 1 & 1.1159 & 102 & 270 & 13.2123 & 0.92 \\
\hline 2 & 1.1136 & 104 & 264 & 13.2187 & 0.94 \\
\hline 3 & 1.1015 & 109 & 246 & 13.2359 & 0.99 \\
\hline 4 & 1.096 & 112 & 239 & 13.2418 & 1.01 \\
\hline
\end{tabular}


Table 75. Uranium Isotopic Composition.

\begin{tabular}{|c|c|c|}
\hline Isotope & $\begin{array}{c}\text { wt \% (HEU-SOL-THERM- } \\
\mathbf{0 0 9 , - 0 1 1 , - 0 1 2})\end{array}$ & $\begin{array}{c}\text { wt \% (HEU-SOL-THERM- } \\
010)\end{array}$ \\
\hline$U-234$ & 0.98 & 1.1 \\
\hline$U-235$ & 93.18 & 93.13 \\
\hline$U-236$ & 0.50 & 0.50 \\
\hline$U-238$ & 5.34 & 5.27 \\
\hline
\end{tabular}

\subsubsection{Bias and Uncertainty}

Figure 5 provides a plot of the calculated $k_{\text {eff }}$ values versus the AEG for this group.

Figure 5. $K_{e f}$ versus Average Energy Group.

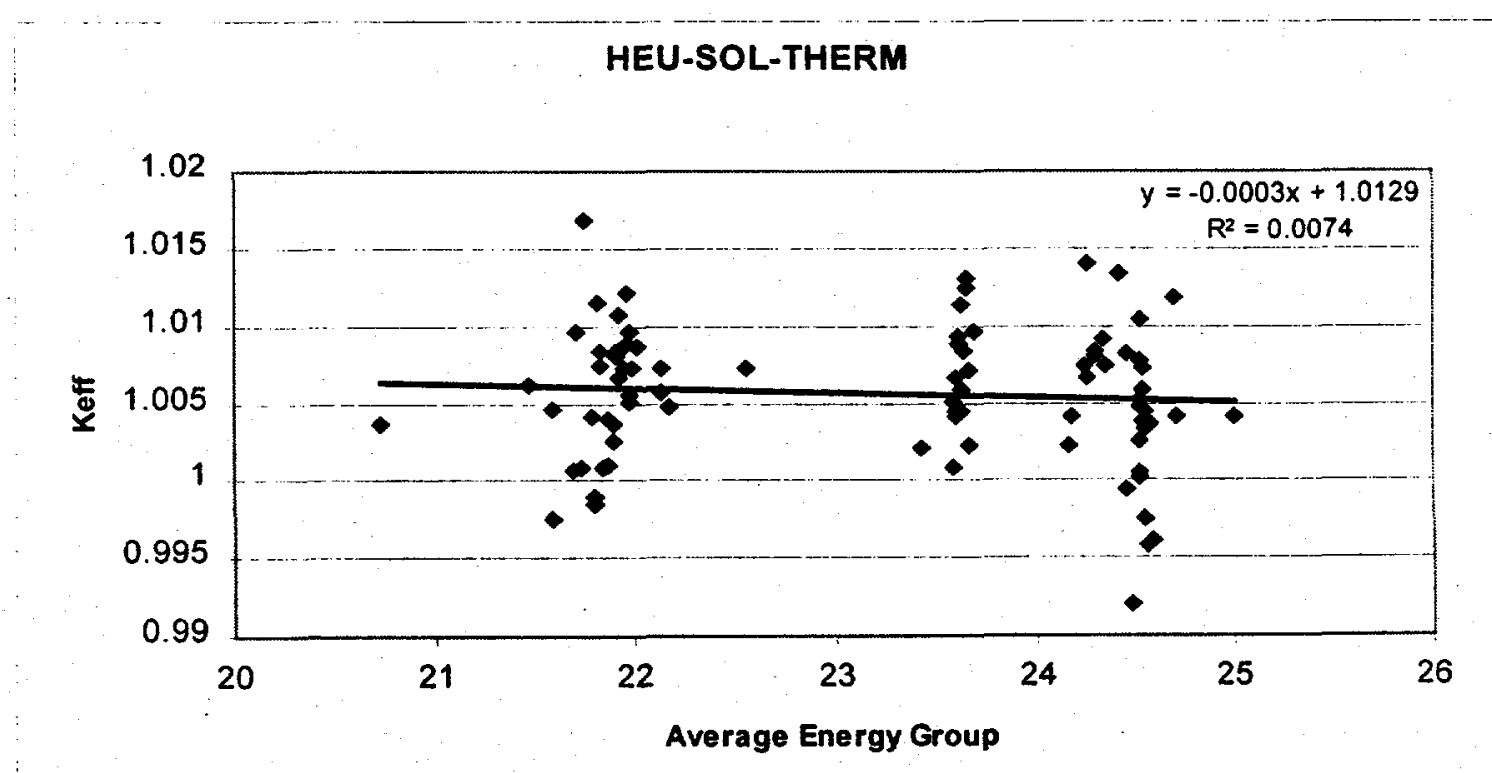

The data was determined to be normal by the Chi-squared test as outlined in Reference 4 . The poor coefficient of fit for the linear regression proves that no trend can be established in the data. An attempt to fit this data to the curves specified in Reference 4 also failed Therefore, a lower tolerance limit was calculated using Equation 1 on page 13.

A single-sided lower tolerance limit of 0.994 was calculated for the 85 experiments.

Table 76 summarizes the results from the statistical analysis for this group. 
Table 76. Results from Statistical Analysis.

\begin{tabular}{|l|c|}
\hline & $\begin{array}{c}\text { All 85 Experiments } \\
\text { (WEIGHTED DATA) }\end{array}$ \\
\hline One-sided Lower Tolerance Factor (U) & 2.065 \\
\hline Sqrt of Pooled Variance $(\mathbf{S p})$ & $5.597 \mathrm{E}-03$ \\
\hline Variance About the Mean $\left(\mathbf{S}^{2}\right)$ & $1.904 \mathrm{E}-05$ \\
\hline Average Uncertainty $\left(\sigma^{2}\right)$ & $1.228 \mathrm{E}-05$ \\
\hline Average $\mathrm{k}_{\text {eff }}$ & 1.0060 \\
\hline Lower Tolerance Limit & 0.994 \\
\hline
\end{tabular}

\subsubsection{Limitations}

The material data of the experiments used in this evaluation are limited in two fashions. First, the experimental data are limited to a small range of uranium enrichment. The majority of the experiments are enriched to $\sim 93 \%$, while six experiments had an enrichment of $80 \%$. Second, the reflector materials are limited to Plexiglas, water, and concrete. The lower tolerance limits developed in this evaluation are applicable to those reflectors and enrichments mentioned. Further justification is necessary if other reflectors or uranium enrichments are to be used.

Care should be used to determine the importance of concrete or Plexiglas to the system being modeled. Concrete and Plexiglas compositions vary. For the concrete, water and iron content can have significant effect on calculated $k_{\text {eff }}$ values. Using different MCNP standard concrete compositions can cause variations of up to 0.005 in $\mathrm{k}_{\text {eff. }}$. For Plexiglas, many older chemical analyses did not measure chlorine, which can also have a major effect. 


\subsection{Uranium Compounds (Low Enrichment) ${ }^{8}$}

\subsubsection{Area of Applicability}

This section presents the MCNP validation analysis for the low enriched uranium fuel experiments: The results of this analysis present a weighted, (including statistical and experimental uncertainties) single-sided lower tolerance limit for the MCNP-4B code system with the ENDF/B-V cross section libraries. The MCNP user should employ the F-4 flux tally to obtain the average energy to assure that the evaluated system is contained within the applicable neutron spectrum. Key areas of applicability for these experiments include:

1. Fuel:

2. Moderation:

3. Enrichment:

4. Moderating Material:

5. Reflecting Material:

6. Geometry:

7. Neutron Spectrum ${ }^{\circ}$ :
Uranium

H/U-235: 100-1400

Low (2-10 wt \% U-235)

Water

Steel, Lead, Water or None

Thin Rod Lattices, Spheres and Cylinders

$22<4 \mathrm{~V} / \mathrm{S}<80$

Thermal; $0.051-0.34 \mathrm{eV}$

AEG: 21.84-23.61

\subsubsection{System Description}

In support of this validation, seventy-one low enriched uranium fuel experiments were marked as acceptable and extracted from the International Handbook of Evaluated Criticality Benchmark Experiments. This validation consisted of low enriched compounds and solutions and is detailed further in the following paragraphs.

\subsubsection{1 $\mathrm{UO}_{2}$ Rods at $2.35 \%$ and $4.31 \% \mathrm{U}-235$}

These critical experiments (described in LEU-COMP-THERM-001 $1^{5}, 002^{5}, 010^{5}$ and $017^{5}$ ) are a series of measurements performed at Pacific Northwest Laboratory (PNL) in the late sixties. They consist of $\mathrm{UO}_{2}$ rod lattices at various pitches, various separations between lattice blocks, and with different reflectors. From the four evaluations 51 measurements were chosen. These include measurements with water, steel and lead reflectors and at lattice pitches of $1.684,1.892,2.032$, and $2.54 \mathrm{~cm}$. The fuel rods were a nominal $1.27 \mathrm{~cm}$ diameter and $92 \mathrm{~cm}$ long and arranged in relatively large arrays, e.g. $13 \times 8$ to $25 \times 18$. LEU-COMP-THERM-017 has 29 benchmark experiments but only 19 are included in

\footnotetext{
${ }^{\circ}$ The neutron spectrum represents the average energy of the neutrons causing fission.
} 
this validation. The other 10 experiments had uranium reflectors and consequently, were not considered for this validation.

\subsubsection{2 $\mathrm{UO}_{2} \mathrm{~F}_{2}$ Solutions at $5 \%$}

Four measurements with $\mathrm{UO}_{2} \mathrm{~F}_{2}$ solutions are reported in LEU-SOL-THERM-00 $1^{5}$ and $002^{5}$. One experiment in LEU-SOL-THERM-001, SHEBA-II at Los Alamos National $\mathrm{Lab}$, consists of an isolated stainless steel cylinder with an empty central steel thimble. The three measurements in LEU-SOL-THERM-002 were done at Oak Ridge National Laboratory and include two water-reflected spheres and one bare sphere.

\subsubsection{Uranium Nitrate Solutions at $10 \%$}

The evaluations LEU-SOL-THERM- $003^{5}$ and $004^{5}$ describe experiments with uranium nitrate solutions at a nominal enrichment of $10 \%$ U-235. In LEU-SOL-THERM-003 there are nine measurements made in bare spherical geometry at the Solution Critical Facility of the Institute of Physics and Power Engineering in Obninsk Russia. The evaluation of LEU-SOL-THERM-004 contains descriptions of seven experiments in water-reflected cylinders performed with the Static Experimental Critical Facility (STACY) at the Nuclear Fuel Cycle Safety Engineering Research Facility in the Tokai Research Establishment of the Japan Atomic Energy Research Institute. 


\subsubsection{Bias and Uncertainty}

In Table 77 , the resulting $k_{\text {eff }}$ values are grouped by the nominal U-235 enrichment.

Table 77. Calculated $k_{\mathrm{eff}}$ Values.

\begin{tabular}{|c|c|c|c|}
\hline & Number & Avg. $_{\text {eff }}$ & $\sigma$ \\
\hline All Cases & 71 & 0.9985 & 0.0042 \\
\hline $2 \%$ & 27 & 0.9971 & 0.0028 \\
\hline $5 \%$ & 28 & 1.0006 & 0.0049 \\
\hline $10 \%$ & 16 & 0.9973 & 0.0036 \\
\hline
\end{tabular}

The data is determined to be normal from the Chi-square test. Figure 6 contains the plot of all 71 data points versus the average energy group.

\section{LEUCompounds}

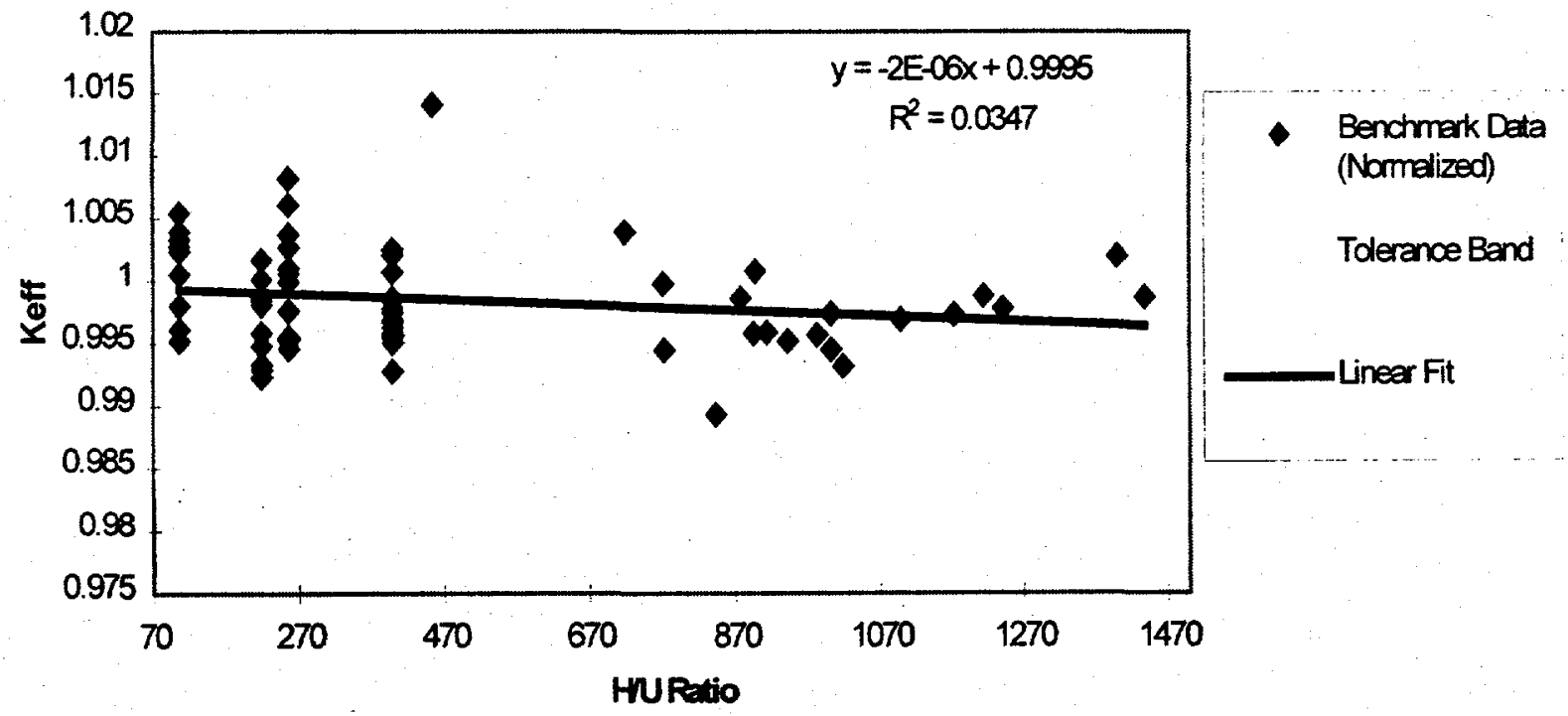

Figure 6. $K_{\text {eff }}$ versus H/U Ratio. 
No trends are apparent, and the coefficient of regression for the fit is poor $\left(R^{2}=0.0347\right)$. Since the data is accepted as normal and the correlation coefficient is close to zero, a single-sided lower tolerance limit is established. Equation 1 on page 13 was used to determine the lower tolerance limit.

A single-sided lower tolerance limit of 0.986 is calculated for the 71 experiments.

Table 78 gives the results from the statistical analysis

Table 78. Results from Statistical Analysis.

\begin{tabular}{|l|c|}
\hline & $\begin{array}{c}\text { All 71 Experiments } \\
\text { (WEIGHTED DATA })\end{array}$ \\
\hline One-sided Lower Tolerance Factor $(\mathbf{U})$ & $2.065^{\mathrm{p}}$ \\
\hline Sqrt. of Pooled Variance $(\mathbf{S p})$ & $5.42 \mathrm{E}-03$ \\
\hline Variance About the Mean $\left(\mathbf{S}^{2}\right)$ & $2.12 \mathrm{E}-05$ \\
\hline Average Uncertainty $\left(\sigma^{2}\right)$ & $8.18 \mathrm{E}-06$ \\
\hline Average $\mathbf{k}_{\text {eff }}$ & 0.9985 \\
\hline Lower Tolerance Limit & 0.986 \\
\hline
\end{tabular}

\subsubsection{Limitations}

Since no clear-cut trend in the average $k_{\text {eff }}$ values appear with respect to enrichment, no extrapolation to higher enrichments is possible even though the data is normally. distributed. The values computed with MCNP (version 4B on the WSMS DEC Alpha workstation) appear to have a downward trend with increasing enrichment. However, extrapolations to higher enrichments would need to be carefully examined and may require the use of an area of applicability margin (AOA $)^{4}$. With this in mind, the lower tolerance band is computed, but its use for extrapolation to higher enrichments can not be conservatively recommended.

\footnotetext{
${ }^{P}$ This is the tolerance factor for $\mathbf{5 0}$ data points; therefore, it is conservative for this data set.
} 


\subsection{REFERENCES}

1. ANSI/ANS 8.1-1983, Nuclear Criticality Safety in Operations with Fissionable Material, 1983.

2. WSMS-CTG-98-0009, "Software Configuration and Control Guidance for MCNP-4B (U)." Nate Jordan, February 1998.

3. EPD-CTG-950030, "Criticality Code Validation Plan (U)", E. F. Trumble, April 1995.

4. WSRC-IM-96-133, WSRC Nuclear Criticality Safety Methods Manual (U), September 1996.

5. NEA/NSC/DOC(95)03, International Handbook of Evaluated Criticality Safety Benchmark Experiments, NEA Nuclear Energy Agency, Organization for Economic Co-operation and Development, September 1998.

6. WSMS-CRT-98-0063, "SCALE 4.3 and MCNP-4B Validation - Criticality Benchmark Evaluation of Uranium Metal Systems", Greg Kessler, September 1998.

7. WSMS-CRT-98-0070, "The Effects of Iron on the Calculated $\mathrm{K}_{\text {eff }}$ of Thermal Uranium Systems (U)", Greg Kessler, September 1998.

8. N-CLC-H-00314, "SCALE and MCNP Validation for Low Enriched Uranium", T.G. Williamson, August 1998.

9. WSRC-RP-99-00564, "Software Configuration and Control Guidance for MCNP4B on the WSRC DFS Workstation System (U)." B.T. Baranko, June 30, 1999.

10. WSRC-RP-99-00563, "WSRC MCNP-4B Test Report (U)." B.T. Baranko, June30, 1999. 
Table A-1. Parameters Used in Pu Metal Validation Calculations.

\begin{tabular}{|c|c|c|c|c|c|}
\hline \multirow[t]{2}{*}{$\begin{array}{l}\text { Experimental Descriptor } \\
\text { Case Number(Input File) }\end{array}$} & \multirow[t]{2}{*}{$\begin{array}{c}\text { Exp. } \\
\mathbf{k}_{\text {efr }}\end{array}$} & \multirow[t]{2}{*}{$\sigma_{\text {exp. }}$} & \multicolumn{3}{|c|}{$\begin{array}{c}\text { Calculated Results } \\
\text { (all } k_{\text {eff }} \text { values normalized to Exp. values) }\end{array}$} \\
\hline & & & $\mathbf{K}_{\text {eff }}$ & $\sigma_{s}$ & AEG (27gr) \\
\hline \multicolumn{6}{|l|}{ PU-MET-FAST-001 } \\
\hline $1(\mathrm{pu}-\mathrm{mt} 001)$ & 1 & 0.0020 & 0.9969 & 0.0006 & 4.22 \\
\hline \multicolumn{6}{|l|}{ PU-MET-FAST-002 } \\
\hline $1(\mathrm{pu}-\mathrm{mt} 002)$ & 1 & 0.0020 & 0.9987 & 0.0006 & 4.22 \\
\hline \multicolumn{6}{|l|}{ PU-MET-FAST-003 } \\
\hline $101(\mathrm{pu}-\mathrm{mt} 003)$ & 1 & 0.0030 & 1.0063 & 0.0006 & 4.25 \\
\hline 102 (pu-mt004) & 1 & 0.0030 & 0.9990 & 0.0007 & 4.82 \\
\hline 103 (pu-mt005) & 1 & 0.0030 & 1.0030 & 0.0007 & 4.26 \\
\hline $105(\mathrm{pu}-\mathrm{mt} 007)$ & 1 & 0.0030 & 1.0022 & 0.0006 & 4.24 \\
\hline \multicolumn{6}{|l|}{ PU-MET-FAST-004 } \\
\hline 207 (pu-mt008) & 1 & 0.0030 & 0.9954 & 0.0013 & 4.51 \\
\hline 208 (pu-mt009) & 1 & 0.0030 & 0.9933 & 0.0012 & 4.55 \\
\hline 209 (pu-mt010) & 1 & 0.0030 & 0.9977 & 0.0012 & 4.56 \\
\hline 210 (pu-mt011) & 1 & 0.0030 & 0.9959 & 0.0012 & 4.55 \\
\hline $211(\mathrm{pu}-\mathrm{mt} 012)$ & 1 & 0.0030 & 0.9949 & 0.0012 & 4.56 \\
\hline 212 (pu-mt013) & 1 & 0.0030 & 0.9924 & 0.0013 & 4.55 \\
\hline 213 (pu-mt014) & 1 & 0.0030 & 0.9935 & 0.0012 & 4.49 \\
\hline 214 (pu-mt015) & 1 & 0.0030 & 0.9935 & 0.0012 & 4.49 \\
\hline 215 (pu-mt016) & 1 & 0.0030 & 0.9933 & 0.0011 & 4.47 \\
\hline \multicolumn{6}{|l|}{ PU-MET-FAST-005 } \\
\hline$I(p u-m t 017)$ & 1 & 0.0013 & 1.0082 & 0.0007 & 4.6 \\
\hline \multicolumn{6}{|l|}{ PU-MET-FAST-006 } \\
\hline $1(\mathrm{pu}-\mathrm{mt} 018)$ & 1 & 0.0030 & 1.0047 & 0.0014 & 4.74 \\
\hline \multicolumn{6}{|l|}{ PU-MET-FAST-008 } \\
\hline $1(\mathrm{pu}-\mathrm{mt} 019)$ & 1 & 0.0006 & 1.0061 & 0.0006 & 4.58 \\
\hline \multicolumn{6}{|l|}{ PU-MET-FAST-009 } \\
\hline $1(\mathrm{pu}-\mathrm{mt} 020)$ & 1 & 0.0027 & 1.0019 & 0.0008 & 4.37 \\
\hline \multicolumn{6}{|l|}{ PU-MET-FAST-010 } \\
\hline $1(\mathrm{pu}-\mathrm{mt} 021)$ & 1 & 0.0018 & 0.9997 & 0.0007 & 4.5 \\
\hline \multicolumn{6}{|l|}{ PU-MET-FAST-011 } \\
\hline $1(\mathrm{pu}-\mathrm{mt} 022)$ & 1 & 0.0010 & 1.0003 & 0.0008 & 6.96 \\
\hline \multicolumn{6}{|l|}{ PU-MET-FAST-016 } \\
\hline $2(\mathrm{pu}-\mathrm{mt} 024)$ & 1 & 0.0038 & 1.0045 & 0.0017 & 5.63 \\
\hline 3 (pu-mt025) & 1 & 0.0033 & 1.0048 & 0.0018 & 6.19 \\
\hline 4 (pu-mt026) & 1 & 0.0030 & 1.0024 & 0.0018 & 5.48 \\
\hline 5 (pu-mt027) & 1 & 0.0034 & 1.0020 & 0.0018 & 7.11 \\
\hline $6(\mathrm{pu}-\mathrm{mt} 028)$ & 1 & 0.0032 & 1.0060 & 0.0018 & 4.22 \\
\hline \multicolumn{6}{|l|}{ PU-MET-FAST-017 } \\
\hline $201(\mathrm{pu}-\mathrm{mt} 029)$ & 1 & 0.0030 & 0.9935 & 0.0012 & 4.22 \\
\hline
\end{tabular}


Table A-1. Parameters Used in Pu Metal Validation Calculations (Continued).

\begin{tabular}{|c|c|c|c|c|c|}
\hline $\begin{array}{c}\text { Experimental Descriptor } \\
\text { Case Number(Input File) }\end{array}$ & $\begin{array}{c}\text { Exp. } \\
\mathbf{k}_{\text {efr }}\end{array}$ & $\sigma_{\text {exp. }}$ & \multicolumn{3}{|c|}{ Calculated Results } \\
\hline & & & $\sigma_{\text {eff }}$ & $\sigma_{\text {s }}$ & AEG (27gr) \\
\hline $\begin{array}{c}\text { PU-MET-FAST-017 } \\
\text { (continued) }\end{array}$ & & & & & \\
\hline 202 (pu-mt030) & 1 & 0.0030 & 0.9983 & 0.0012 & 4.37 \\
\hline 203 (pu-mt031) & 1 & 0.0030 & 0.9994 & 0.0012 & 4.37 \\
\hline 204 (pu-mt032) & 1 & 0.0030 & 0.9974 & 0.0013 & 9.61 \\
\hline 205 (pu-mt033) & 1 & 0.0030 & 1.0054 & 0.0013 & 9.99 \\
\hline PU-MET-FAST-022 & & & & & \\
\hline 1 (pu-mt035) & 1 & 0.0021 & 0.9987 & 0.0006 & 10.04 \\
\hline PU-MET-FAST-023 & & & & & \\
\hline 1 (pu-mt036) & 1 & 0.0020 & 0.9964 & 0.0010 & 10.04 \\
\hline PU-MET-FAST-037 & & & & & \\
\hline 1 (pu-mt037) & 1 & 0.0046 & 0.9990 & 0.0024 & 6.78 \\
\hline 2 (pu-mt038) & 1 & 0.0046 & 1.0016 & 0.0017 & 7.38 \\
\hline 3 (pu-mt039) & 1 & 0.0046 & 1.0025 & 0.0016 & 7.44 \\
\hline 4 (pu-mt040) & 1 & 0.0046 & 1.0031 & 0.0017 & 7.6 \\
\hline 5 (pu-mt041) & 1 & 0.0046 & 1.0010 & 0.0017 & 7.89 \\
\hline 6 (pu-mt042) & 1 & 0.0038 & 1.0027 & 0.0017 & 8.45 \\
\hline 7 (pu-mt043) & 1 & 0.0038 & 1.0031 & 0.0017 & 8.39 \\
\hline 8 (pu-mt044) & 1 & 0.0035 & 1.0008 & 0.0018 & 8.99 \\
\hline 9 (pu-mt045) & 1 & 0.0038 & 1.0020 & 0.0018 & 9.04 \\
\hline 10 (pu-mt046) & 1 & 0.0038 & 1.0025 & 0.0018 & 8.69 \\
\hline 11 (pu-mt047) & 1 & 0.0041 & 0.9978 & 0.0017 & 7.45 \\
\hline 12 (pu-mt048) & 1 & 0.0039 & 1.0010 & 0.0017 & 8.71 \\
\hline 13 (pu-mt049) & 1 & 0.0034 & 0.9995 & 0.0018 & 9.52 \\
\hline 14 (pu-mt050) & 1 & 0.0033 & 1.0047 & 0.0018 & 9.26 \\
\hline 15 (pu-mt051) & 1 & 0.0033 & 1.0077 & 0.0018 & 9.11 \\
\hline 16 (pu-mt052) & 1 & 0.0036 & 1.0078 & 0.0017 & 8.6 \\
\hline
\end{tabular}


Table A-2. Parameters Used in Pu Solutions Validation Calculations.

\begin{tabular}{|c|c|c|c|c|c|}
\hline \multirow[t]{2}{*}{$\begin{array}{l}\text { Experimental Descriptor } \\
\text { Case Number(Input File) }\end{array}$} & \multirow[t]{2}{*}{$\begin{array}{l}\text { Exp. } \\
k_{\text {eff }}\end{array}$} & \multirow[t]{2}{*}{$\sigma_{\text {exp. }}$} & \multicolumn{3}{|c|}{$\begin{array}{c}\text { Calculated Results } \\
\text { (all } k_{\text {eff }} \text { values normalized to Exp. values) }\end{array}$} \\
\hline & & & $k_{\text {eff }}$ & $\sigma_{3}$ & $\mathrm{H} / \mathrm{Pu}$ \\
\hline \multicolumn{6}{|l|}{ PU-SOL-THERM-009 } \\
\hline$I(p u-s \mid 001)$ & 1.0003 & 0.0033 & 1.0192 & 0.0006 & 2648.2 \\
\hline $2(p u-s 1002)$ & 1.0003 & 0.0033 & 1.0241 & 0.0006 & 2778.9 \\
\hline $3(\mathrm{pu}-\mathrm{s} 1003)$ & 1.0003 & 0.0033 & 1.0238 & 0.0006 & 2802.8 \\
\hline \multicolumn{6}{|l|}{ PU-SOL-THERM-011 } \\
\hline $16-1(\mathrm{pu}-\mathrm{s} 1004)$ & $T$ & 0.0052 & 1.0174 & 0.0010 & 765 \\
\hline $16-2(\mathrm{pu}-\mathrm{s} 1005)$ & 1 & 0.0052 & 1.0235 & 0.0014 & 736 \\
\hline $16-3(\mathrm{pu}-\mathrm{s} 1006)$ & 1 & 0.0052 & 1.0233 & 0.0013 & 691 \\
\hline $16-4(\mathrm{pu}-\mathrm{s} 1007)$ & 1 & 0.0052 & 1.0202 & 0.0013 & 682 \\
\hline $16-5$ (pu-s1008) & 1 & 0.0052 & 1.0155 & 0.0011 & 574 \\
\hline $18-1(\mathrm{pu}-\mathrm{s} 1009)$ & 1 & 0.0052 & 1.0006 & 0.0012 & 1208 \\
\hline $18-2(p u-s 1010)$ & 1 & 0.0052 & 1.0081 & 0.0010 & 1151 \\
\hline $18-3(\mathrm{pu}-\mathrm{s} 1011)$ & 1 & 0.0052 & 1.0029 & 0.0012 & 1158 \\
\hline 18-4 (pu-sl012) & 1 & 0.0052 & 1.0002 & 0.0012 & 1100 \\
\hline $18-5(\mathrm{pu}-\mathrm{s} 1013)$ & 1 & 0.0052 & 1.0110 & 0.0010 & 1039 \\
\hline $18-6$ (pu-sl13a) & 1 & 0.0052 & 1.0062 & 0.0010 & 908 \\
\hline $18-7(\mathrm{pu}-\mathrm{s} \mid 13 \mathrm{~b})$ & 1 & 0.0052 & 1.0063 & 0.0010 & 1103 \\
\hline \multicolumn{6}{|l|}{ PU-SOL-THERM-012 } \\
\hline $1(\mathrm{pu}-\mathrm{s} 1014)$ & 1 & 0.0043 & 1.0117 & 0.0007 & 1721.6 \\
\hline 2 (pu-s1015) & 1 & 0.0043 & 1.0124 & 0.0006 & 1920.1 \\
\hline $3(\mathrm{pu}-\mathrm{s} 1016)$ & 1 & 0.0058 & 1.0131 & 0.0006 & 2035.4 \\
\hline $4(\mathrm{pu}-\mathrm{s} 1017)$ & 1 & 0.0058 & 1.0133 & 0.0005 & 2311.6 \\
\hline 5 (pu-s1018) & 1 & 0.0058 & 1.0145 & 0.0005 & 2573.3 \\
\hline $6(\mathrm{pu}-\mathrm{s} 1019)$ & 1 & 0.0007 & 1.0095 & 0.0010 & 309.1 \\
\hline 7 (pu-s1020) & 1 & 0.0013 & 1.0087 & 0.0009 & 398.8 \\
\hline $8(\mathrm{pu}-\mathrm{s} 1021)$ & 1 & 0.0013 & 1.0109 & 0.0007 & 632.5 \\
\hline $9(\mathrm{pu}-\mathrm{s} 1022)$ & 1 & 0.0043 & 1.0157 & 0.0008 & 1054.1 \\
\hline $10(\mathrm{pu}-\mathrm{s} 1023)$ & 1 & 0.0043 & 1.0122 & 0.0006 & 1251.8 \\
\hline $11(\mathrm{pu}-\mathrm{s} 1024)$ & 1 & 0.0043 & 1.0140 & 0.0007 & 1566.7 \\
\hline $12(\mathrm{pu}-\mathrm{s} 1025)$ & 1 & 0.0043 & 1.0158 & 0.0006 & 1721.6 \\
\hline $13(\mathrm{pu}-\mathrm{s} 1026)$ & 1 & 0.0058 & 1.0151 & 0.0004 & 2573.3 \\
\hline \multicolumn{6}{|l|}{ PU-SOL-THERM-001 } \\
\hline $1(\mathrm{pu}-\mathrm{s} 1037)$ & 1 & 0.005 & 1.0086 & 0.0014 & 371.3 \\
\hline $2(\mathrm{pu}-\mathrm{s} 1038)$ & 1 & 0.005 & 1.0136 & 0.0015 & 271.5 \\
\hline $3(\mathrm{pu}-\mathrm{s} 1039)$ & 1 & 0.005 & 1.0133 & 0.0014 & 215.9 \\
\hline 4 (pu-sl040) & 1 & 0.005 & 1.0090 & 0.0015 & 190.4 \\
\hline $5(\mathrm{pu}-\mathrm{s} 1041)$ & 1 & 0.005 & 1.0103 & 0.0014 & 180.2 \\
\hline $6(\mathrm{pu}-\mathrm{sl} 042)$ & 1 & 0.005 & 1.0092 & 0.0015 & 91.2 \\
\hline \multicolumn{6}{|l|}{ PU-SOL-THERM-002 } \\
\hline $1(\mathrm{pu}-\mathrm{sl} 1043)$ & 1 & 0.0047 & 1.0108 & 0.0012 & 524 \\
\hline $2(\mathrm{pu}-\mathrm{s} 1044)$ & 1 & 0.0047 & 1.0122 & 0.0013 & 505 \\
\hline $3(\mathrm{pu}-\mathrm{s} 1045)$ & 1 & 0.0047 & 1.0096 & 0.0013 & 451 \\
\hline 4 (pu-s1046) & 1 & 0.0047 & 1.0098 & 0.0012 & 421 \\
\hline 5 (pu-s1047) & 1 & 0.0047 & 1.0133 & 0.0012 & 393 \\
\hline
\end{tabular}


Table A-2. Parameters Used in Pu Solutions Validation Calculations (Continued).

\begin{tabular}{|c|c|c|c|c|c|}
\hline \multirow[t]{2}{*}{$\begin{array}{l}\text { Experimental Descriptor } \\
\text { Case Number(Input File) }\end{array}$} & \multirow[t]{2}{*}{$\begin{array}{c}\text { Exp. } \\
k_{\text {eff }}\end{array}$} & \multirow[t]{2}{*}{$\sigma_{\text {exp. }}$} & \multicolumn{3}{|c|}{$\begin{array}{c}\text { Calculated Results } \\
\text { (all } k_{\text {eff }} \text { values normalized to Exp. values) }\end{array}$} \\
\hline & & & $\mathbf{k}_{\text {eff }}$ & $\sigma_{\mathrm{s}}$ & $\mathbf{H} / \mathbf{P u}$ \\
\hline \multicolumn{6}{|l|}{$\begin{array}{c}\text { PU-SOL-THERM-002 } \\
\text { (continued) }\end{array}$} \\
\hline $6(\mathrm{pu}-\mathrm{s} 1048)$ & 1 & 0.0047 & 1.0109 & 0.0013 & 344 \\
\hline 7 (pu-sl049) & 1 & 0.0047 & 1.0123 & 0.0013 & 309 \\
\hline \multicolumn{6}{|l|}{ PU-SOL-THERM-003 } \\
\hline $\mathrm{I}(\mathrm{pu}-\mathrm{s} \mid 050)$ & 1 & 0.0047 & 1.0104 & 0.0012 & 788 \\
\hline $2(\mathrm{pu}-\mathrm{s} 1051)$ & 1 & 0.0047 & 1.0089 & 0.0011 & 756 \\
\hline $3(\mathrm{pu}-\mathrm{s} 1052)$ & 1 & 0.0047 & 1.0093 & 0.0012 & 698.9 \\
\hline $4(\mathrm{pu}-\mathrm{s} 1053)$ & 1 & 0.0047 & 1.0107 & 0.0012 & 681.7 \\
\hline 5 (pu-s1054) & 1 & 0.0047 & 1.0120 & 0.0012 & 626.7 \\
\hline 6 (pu-sl055) & 1 & 0.0047 & 1.0135 & 0.0012 & 562.8 \\
\hline 7 (pu-sl056) & 1 & 0.0047 & 1.0148 & 0.0012 & 737.8 \\
\hline $8(\mathrm{pu}-\mathrm{s} 1057)$ & 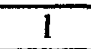 & 0.0047 & 1.0144 & 0.0012 & 714.3 \\
\hline \multicolumn{6}{|l|}{ PU-SOL-THERM-004 } \\
\hline $1(\mathrm{pu}-\mathrm{s} 1058)$ & 1 & 0.0047 & 1.0096 & 0.0013 & 987 \\
\hline $2(\mathrm{pu}-\mathrm{s} 1059)$ & 1 & 0.0047 & 1.0072 & 0.0012 & 977 \\
\hline $3(\mathrm{pu}-\mathrm{s} \mid 060)$ & 1 & 0.0047 & 1.0093 & 0.0013 & 935 \\
\hline $4(\mathrm{pu}-\mathrm{s} 1061)$ & 1 & 0.0047 & 1.0077 & 0.0013 & 889 \\
\hline $5(\mathrm{pu}-\mathrm{sl} 062)$ & l & 0.0047 & 1.0105 & 0.0013 & 942 \\
\hline $6(\mathrm{pu}-\mathrm{s} \mid 063)$ & 1 & 0.0047 & 1.0095 & 0.0012 & 927 \\
\hline 7 (pu-s1064) & 1 & 0.0047 & 1.0126 & 0.0012 & 892 \\
\hline 8 (pu-sl065) & 1 & 0.0047 & 1.0077 & 0.0012 & 869 \\
\hline $9(p u-s \mid 066)$ & 1 & 0.0047 & 1.0082 & 0.0013 & 805 \\
\hline $10(\mathrm{pu}-\mathrm{s} 1067)$ & 1 & 0.0047 & 1.0105 & 0.0013 & 689 \\
\hline $11(\mathrm{pu}-\mathrm{s} 1068)$ & 1 & 0.0047 & 1.0086 & 0.0014 & 592 \\
\hline $12(\mathrm{pu}-\mathrm{s} 1069)$ & 1 & 0.0047 & 1.0131 & 0.0012 & $\overline{893}$ \\
\hline $13(\mathrm{pu}-\mathrm{s} 1070)$ & 1 & 0.0047 & 1.0080 & 0.0013 & 903 \\
\hline \multicolumn{6}{|l|}{ PU-SOL-THERM-005 } \\
\hline $1(\mathrm{pu}-\mathrm{sl} 1071)$ & 1 & 0.0047 & 1.0092 & 0.0012 & 902.8 \\
\hline $2(\mathrm{pu}-\mathrm{s} 1072)$ & 1 & 0.0047 & 1.0107 & 0.0012 & 867.7 \\
\hline $3(\mathrm{pu}-\mathrm{s} 1073)$ & 1 & 0.0047 & 1.0110 & 0.0011 & 834.4 \\
\hline $4(\mathrm{pu}-\mathrm{s} 1074)$ & 1 & 0.0047 & 1.0116 & 0.0012 & 765.2 \\
\hline $5(\mathrm{pu}-\mathrm{s} 1075)$ & 1 & 0.0047 & 1.0126 & 0.0011 & 694.1 \\
\hline $6(\mathrm{pu}-\mathrm{s} 1076)$ & 1 & 0.0047 & 1.0119 & 0.0011 & 633.4 \\
\hline 7 (pu-s1077) & 1 & 0.0047 & 1.0128 & 0.0012 & 580.6 \\
\hline $8(\mathrm{pu}-\mathrm{sl078)}$ & 1 & 0.0047 & 1.0039 & 0.0012 & 868.7 \\
\hline 9 (pu-s1079) & 1 & 0.0047 & 1.0105 & 0.0011 & 825.1 \\
\hline \multicolumn{6}{|l|}{ PU-SOL-THERM-006 } \\
\hline $1(\mathrm{pu}-\mathrm{s} 1080)$ & 1 & 0.0035 & 1.0092 & 0.0011 & 1061 \\
\hline 2 (pu-sl081) & 1 & 0.0035 & 1.0081 & 0.0011 & 1018 \\
\hline $3(\mathrm{pu}-\mathrm{s} 1082)$ & 1 & 0.0035 & 1.0105 & 0.0010 & 940 \\
\hline \multicolumn{6}{|l|}{ PU-SOL-THERM-007 } \\
\hline $1(\mathrm{pu}-\mathrm{s} 1083)$ & 1 & 0.0048 & 1.0116 & 0.0012 & 109.6 \\
\hline 2 (pu-sl084) & 1 & 0.0048 & 1.0044 & 0.0012 & 114 \\
\hline 3 (pu-s1085) & 1 & 0.0048 & 1.0119 & 0.0012 & 267.5 \\
\hline 4 (pu-s1086) & 1 & 0.0048 & 1.0080 & 0.0012 & 262 \\
\hline
\end{tabular}


Table A-2. Parameters Used in Pu Solutions Validation Calculations (Continued).

\begin{tabular}{|c|c|c|c|c|c|}
\hline \multirow[t]{2}{*}{$\begin{array}{l}\text { Experimental Descriptor } \\
\text { Case Number(Input File) }\end{array}$} & \multirow[t]{2}{*}{$\begin{array}{l}\text { Exp. } \\
\mathbf{k}_{\text {eff }}\end{array}$} & \multirow[t]{2}{*}{$\sigma_{\text {exp. }}$} & \multicolumn{3}{|c|}{$\begin{array}{c}\text { Calculated Results } \\
\text { (all } k_{\text {eff }} \text { values normalized to Exp. values) }\end{array}$} \\
\hline & & & $\mathrm{k}_{\mathrm{eff}}$ & $\sigma_{s}$ & $\mathrm{H} / \mathrm{Pu}$ \\
\hline \multicolumn{6}{|l|}{$\begin{array}{l}\text { PU-SOL-THERM-007 } \\
\text { (continued) }\end{array}$} \\
\hline $5(\mathrm{pu}-\mathrm{s} 1087)$ & $\mathrm{I}$ & 0.0048 & 1.0086 & 0.0012 & 265.8 \\
\hline $6(\mathrm{pu}-\mathrm{s} 1088)$ & 1 & 0.0048 & 1.0033 & 0.0012 & 258.5 \\
\hline 7 (pu-sl089) & 1 & 0.0048 & 1.0024 & 0.0012 & 259.7 \\
\hline 8 (pu-s1090) & 1 & 0.0048 & 1.0054 & 0.0012 & 285 \\
\hline \multicolumn{6}{|l|}{ PU-SOL-THERM-010 } \\
\hline $1(\mathrm{pu}-\mathrm{s} \mathbf{1 0 9 1})$ & 1 & 0.0048 & 1.0215 & 0.0011 & 266.9 \\
\hline 2 (pu-sl092) & 1 & 0.0048 & 1.0195 & 0.0011 & 356.9 \\
\hline 3 (pu-sl093) & 1 & 0.0048 & 1.0140 & 0.0010 & 484.2 \\
\hline 4 (pu-sl094) & 1 & 0.0048 & 1.0181 & 0.0010 & 485 \\
\hline 5 (pu-sl095) & 1 & 0.0048 & 1.0158 & 0.0010 & 558.1 \\
\hline 6 (pu-s1096) & 1 & 0.0048 & 1.0157 & 0.0010 & 558.1 \\
\hline 7 (pu-s1097) & 1 & 0.0048 & 1.0096 & 0.0010 & 605.9 \\
\hline 8 (pu-s1098) & 1 & 0.0048 & 1.0104 & 0.0009 & 665.4 \\
\hline 9 (pu-sl099) & 1 & 0.0048 & 1.0197 & 0.0011 & 414.3 \\
\hline $10(\mathrm{pu}-\mathrm{s} 1100)$ & 1 & 0.0048 & 1.0079 & 0.0010 & 535.2 \\
\hline 11 (pu-sl101) & 1 & 0.0048 & 1.0161 & 0.0010 & 543.4 \\
\hline 12 (pu-s1102) & 1 & 0.0048 & 1.0156 & 0.0010 & 618.4 \\
\hline $13(p u-s 1103)$ & 1 & 0.0048 & 1.0231 & 0.0010 & 728.1 \\
\hline $14(\mathrm{pu}-\mathrm{s} \mid \mathrm{l} 04)$ & 1 & 0.0048 & 1.0155 & 0.0010 & 849.7 \\
\hline
\end{tabular}


Table A-3. Parameters Used in Uranium Metal (Fast) Validation Calculations.

\begin{tabular}{|c|c|c|c|c|c|}
\hline \multirow[t]{2}{*}{$\begin{array}{l}\text { Experimental Descriptor } \\
\text { Case Number(Input File) }\end{array}$} & \multirow[t]{2}{*}{$\begin{array}{c}\text { Exp. } \\
k_{\text {efr }}\end{array}$} & \multirow[t]{2}{*}{$\sigma_{\text {exp }}$} & \multicolumn{3}{|c|}{$\begin{array}{l}\text { Calculated Results } \\
\text { (all } k_{\mathrm{eff}} \text { values normalized to Exp. values) }\end{array}$} \\
\hline & & & $\mathbf{k}_{\text {efr }}$ & $\sigma_{\mathrm{s}}$ & AEG (27gr) \\
\hline \multicolumn{6}{|l|}{ HEU-MET-FAST-001 } \\
\hline 1 (heumt002) & 1 & 0.0010 & 0.9993 & 0.0010 & 4.85 \\
\hline 2 (heumt001) & 1 & 0.0010 & 0.9985 & 0.0008 & 4.86 \\
\hline \multicolumn{6}{|l|}{ HEU-MET-FAST-002 } \\
\hline 1 (heumt003) & 1 & 0.0030 & 1.0028 & 0.0011 & 4.87 \\
\hline 2 (heumt004) & 1 & 0.0030 & 1.0060 & 0.0011 & 4.89 \\
\hline 3 (heumt005) & 1 & 0.0030 & 1.0014 & 0.0011 & 4.89 \\
\hline 4 (heumt006) & 1 & 0.0030 & 1.0009 & 0.0010 & 4.91 \\
\hline 5 (heumt007) & 1 & 0.0030 & 1.0007 & 0.0011 & 4.91 \\
\hline 6 (heumt008) & 1 & 0.0030 & 1.0040 & 0.0010 & 4.90 \\
\hline \multicolumn{6}{|l|}{ HEU-MET-FAST-003 } \\
\hline $1($ heumt009) & 1 & 0.0050 & 0.9938 & 0.0010 & 4.88 \\
\hline 2 (heumt010) & 1 & 0.0050 & 0.9931 & 0.0010 & 4.87 \\
\hline 3 (heumt011) & 1 & 0.0050 & 1.0001 & 0.0011 & 4.87 \\
\hline 4 (heumt012) & 1 & 0.0050 & 1.0002 & 0.0010 & 4.86 \\
\hline 5 (heumt013) & 1 & 0.0050 & 1.0045 & 0.0010 & 4.87 \\
\hline 6 (heumt014) & 1 & 0.0050 & 1.0018 & 0.0010 & 4.87 \\
\hline 7.(heumt015) & 1 & 0.0050 & 1.0009 & 0.0012 & 4.89 \\
\hline 8 (heumt016) & 1 & 0.0050 & 0.9983 & 0.0010 & 5.20 \\
\hline 9 (heumt017) & 1 & 0.0050 & 0.9986 & 0.0009 & 5.03 \\
\hline 10 (heumt018) & 1 & 0.0050 & 1.0021 & 0.0009 & 5.37 \\
\hline 11 (heumt019) & 1 & 0.0050 & 1.0036 & 0.0010 & 5.39 \\
\hline \multicolumn{6}{|l|}{ HEU-MET-FAST-004 } \\
\hline 2 (heumt 022) & 1.002 & 0.0020 & 0.9985 & 0.0011 & 8.50 \\
\hline \multicolumn{6}{|l|}{ HEU-MET-FAST-007 } \\
\hline 1 (heumt023) & 0.9971 & 0.0001 & 0.9965 & 0.0009 & 4.84 \\
\hline 2 (heumt024) & 0.9986 & 0.0001 & 0.9954 & 0.0010 & 5.39 \\
\hline 3 (heumt025) & 1.0012 & 0.0001 & 0.9918 & 0.0011 & 5.63 \\
\hline 4 (heumt026) & 0.997 & 0.0001 & 0.9963 & 0.0011 & 5.73 \\
\hline 5 (heumt 027 ) & 1 & 0.0001 & 0.9930 & 0.0011 & 5.96 \\
\hline 6 (heumt028) & 1.0028 & 0.0001 & 0.9986 & 0.0012 & 6.40 \\
\hline 7 (heumt029) & 0.9996 & 0.0001 & 0.9950 & 0.0012 & 6.17 \\
\hline 8 (heumt030) & 0.9992 & 0.0001 & 0.9957 & 0.0011 & 6.14 \\
\hline 9 (heumt 031 ) & 1.0017 & 0.0008 & 0.9932 & 0.0011 & 6.27 \\
\hline 10 (heumt032) & 1 & 0.0001 & 0.9907 & 0.0014 & 8.08 \\
\hline 11 (heumt033) & 0.9982 & 0.0001 & 0.9918 & 0.0013 & 9.65 \\
\hline 12 (heumt034) & 0.9951 & 0.0001 & 0.9909 & 0.0013 & 9.99 \\
\hline 13 (heumt 035 ) & 1.0009 & 0.0001 & 0.9929 & 0.0014 & 10.65 \\
\hline 14 (heumt036) & 0.9983 & 0.0001 & 0.9921 & 0.0015 & 10.07 \\
\hline 15 (heumt037) & 0.9978 & 0.0001 & 0.9910 & 0.0013 & 10.54 \\
\hline 16 (heumt038) & 0.9988 & 0.0001 & 0.9919 & 0.0013 & 10.57 \\
\hline 17 (heumt039) & 0.9972 & 0.0001 & 0.9913 & 0.0014 & 12.83 \\
\hline 18 (heumt040) & 0.9991 & 0.0001 & 0.9945 & 0.0014 & 12.88 \\
\hline
\end{tabular}


Table A-3. Parameters Used in Uranium Metal (Fast) Validation Calculations (Continued).

\begin{tabular}{|c|c|c|c|c|c|}
\hline \multirow[t]{2}{*}{$\begin{array}{l}\text { Experimental Descriptor } \\
\text { Case Number(Input File) }\end{array}$} & \multirow[t]{2}{*}{$\begin{array}{r}\text { Exp. } \\
k_{\text {err }}\end{array}$} & \multirow[t]{2}{*}{$\sigma_{\text {exp. }}$} & \multicolumn{3}{|c|}{$\begin{array}{c}\text { Calculated Results } \\
\text { (all } k_{\mathrm{efr}} \text { values normalized to Exp. values) }\end{array}$} \\
\hline & & & $\mathbf{k}_{\mathrm{efr}}$ & $\sigma_{s}$ & AEG (27gr) \\
\hline \multicolumn{6}{|l|}{$\begin{array}{l}\text { HEU-MET-FAST-007 } \\
\text { (continued) }\end{array}$} \\
\hline 19 (heumt041) & 0.9983 & 0.0001 & 0.9960 & 0.0009 & 4.84 \\
\hline 20 (heumt042) & 0.9981 & 0.0001 & 0.9931 & 0.0011 & 6.13 \\
\hline 21 (heumt043) & 0.9987 & 0.0001 & 0.9916 & 0.0012 & 6.20 \\
\hline 22 (heumt044) & 0.9994 & 0.0001 & 0.9922 & 0.0011 & 6.29 \\
\hline 23 (heumt045) & 0.9993 & 0.0001 & 0.9916 & 0.0012 & 7.37 \\
\hline 24 (heumt046) & 1.0001 & 0.0001 & 0.9907 & 0.0012 & 7.45 \\
\hline 25 (heumt047) & 0.999 & 0.0001 & 0.9928 & 0.0012 & 8.23 \\
\hline 26 (heumt048) & 0.9997 & 0.0001 & 0.9919 & 0.0012 & 8.31 \\
\hline 27 (heumt049) & 0.9965 & 0.0002 & 0.9959 & 0.0012 & 5.44 \\
\hline 28 (heumt050) & 0.9987 & 0.0002 & 0.9911 & 0.0010 & 5.89 \\
\hline 29 (heumt 051$)$ & 0.9978 & 0.0002 & 0.9940 & 0.0012 & 6.36 \\
\hline 30 (heumt052) & 0.9981 & 0.0002 & 0.9936 & 0.0011 & 8.54 \\
\hline 31 (heumt053) & 1.0013 & 0.0002 & 0.9969 & 0.0013 & 11.06 \\
\hline 32 (heumt 054 ) & 0.9959 & 0.0001 & 1.0045 & 0.0010 & 5.02 \\
\hline 33 (heumt055) & 0.9995 & 0.0001 & 1.0062 & 0.0011 & 5.12 \\
\hline 34 (heumt056) & 0.9977 & 0.0001 & 1.0085 & 0.0010 & 5.23 \\
\hline 35 (heumt057) & 1.0011 & 0.0001 & 0.9863 & 0.0012 & 10.01 \\
\hline 36 (heumt058) & 0.9999 & 0.0001 & 0.9960 & 0.0012 & 10.62 \\
\hline 37 (heumt059) & 0.9988 & 0.0001 & 0.9986 & 0.0014 & 11.19 \\
\hline 38 (heumt060) & 1 & 0.0001 & 0.9929 & 0.0012 & 11.36 \\
\hline 39 (heumt061) & 1.0018 & 0.0001 & 0.9954 & 0.0014 & 11.37 \\
\hline 40 (heumt062) & 1.0013 & 0.0001 & 0.9989 & 0.0013 & 11.35 \\
\hline 41 (heumt063) & 0.9994 & 0.0001 & 0.9970 & 0.0014 & 13.15 \\
\hline 42 (heumt064) & 1.0016 & 0.0001 & 0.9963 & 0.0012 & 13.19 \\
\hline 43 (heumt065) & 0.9998 & 0.0001 & 0.9970 & 0.0015 & 15.81 \\
\hline \multicolumn{6}{|l|}{ HEU-MET-FAST-012 } \\
\hline 1 (heumt088) & 0.9992 & 0.0018 & 0.9945 & 0.0005 & 4.92 \\
\hline \multicolumn{6}{|l|}{ HEU-MET-FAST-013 } \\
\hline 1 (heumt089) & 0.9990 & 0.0015 & 1.0027 & 0.0006 & 4.99 \\
\hline \multicolumn{6}{|l|}{ HEU-MET-FAST-021 } \\
\hline 1 (heumt090) & 1 & 0.0024 & 1.0070 & 0.0006 & 5.09 \\
\hline \multicolumn{6}{|l|}{ HEU-MET-FAST-022 } \\
\hline 1 (heumt091) & 1 & 0.0019 & 0.9929 & 0.0006 & 4.94 \\
\hline \multicolumn{6}{|l|}{ HEU-MET-FAST-023 } \\
\hline 2 (heumt066) & 1 & 0.0052 & 0.9943 & 0.0006 & 5.43 \\
\hline 3 (heumt067) & 1 & 0.0052 & 1.0001 & 0.0007 & 8.33 \\
\hline 4 (heumt068) & 1 & 0.0052 & 1.0023 & 0.0007 & 10.06 \\
\hline 5 (heumt069) & 1 & 0.0052 & 0.9989 & 0.0007 & 10.28 \\
\hline 6 (heumt070) & 1 & 0.0052 & 0.9942 & 0.0006 & 4.87 \\
\hline 7 (heumt07l) & 1 & 0.0052 & 0.9916 & 0.0007 & 5.48 \\
\hline 8 (heumt072) & 1 & 0.0052 & 0.9987 & 0.0007 & 8.66 \\
\hline 9 (heumt 073 ) & 1 & 0.0052 & 0.9975 & 0.0007 & 10.50 \\
\hline
\end{tabular}


Page 76 of 87

$$
10 \text { (heumt074) }
$$

12(heumt075)

\begin{tabular}{|l|l|}
\hline 1 & 0.0052 \\
\hline 1 & 0.0052 \\
\hline
\end{tabular}

\begin{tabular}{|l|l|}
\hline & 0.9949 \\
\hline & 0.9932 \\
\hline
\end{tabular}

\begin{tabular}{|l|l|}
\hline 0.0005 \\
\hline 0.0007 \\
\hline
\end{tabular}

10.74

5.42

Table A-3. Parameters Used in Uranium Metal (Fast) Validation Calculations (Continued).

\begin{tabular}{|c|c|c|c|c|c|}
\hline \multirow[t]{2}{*}{$\begin{array}{l}\text { Experimental Descriptor } \\
\text { Case Number(Input File) }\end{array}$} & \multirow[t]{2}{*}{$\begin{array}{l}\text { Exp. } \\
k_{\text {eff }}\end{array}$} & \multirow[t]{2}{*}{$\sigma_{\text {exp. }}$} & \multicolumn{3}{|c|}{$\begin{array}{c}\text { Calculated Results } \\
\text { (all } k_{\text {eff }} \text { values normalized to Exp. values) }\end{array}$} \\
\hline & & & $\mathbf{k}_{\mathrm{eff}}$ & $\sigma_{\mathrm{s}}$ & AEG (27gr) \\
\hline \multicolumn{6}{|l|}{$\begin{array}{l}\text { HEU-MET-FAST-023 } \\
\text { (continued) }\end{array}$} \\
\hline 13 (heumt076) & 1 & 0.0052 & 1.0071 & 0.0007 & 8.30 \\
\hline 14 (heumt077) & 1 & 0.0052 & 1.0037 & 0.0007 & 9.97 \\
\hline 15 (heumt078) & 1 & 0.0052 & 0.9987 & 0.0006 & 10.21 \\
\hline 16 (heumt079) & 1 & 0.0052 & 0.9980 & 0.0005 & 4.87 \\
\hline 17 (heumt080) & 1 & 0.0052 & 0.9962 & 0.0005 & 5.46 \\
\hline 18 (heumt081) & 1 & 0.0052 & 0.9977 & 0.0006 & 8.67 \\
\hline 19 (heumt082) & 1 & 0.0052 & 0.9986 & 0.0005 & 10.37 \\
\hline 20 (heumt083) & 1 & 0.0052 & 0.9959 & 0.0005 & 10.59 \\
\hline 21 (heumt 084 ) & 1 & 0.0057 & 0.9942 & 0.0005 & 4.91 \\
\hline 22 (heumt085) & 1 & 0.0052 & 0.9949 & 0.0006 & 10.88 \\
\hline 28 (heumt086) & 1 & 0.0052 & 0.9940 & 0.0005 & 4.86 \\
\hline 29 (heumt087) & 1 & 0.0052 & 0.9955 & 0.0006 & 4.89 \\
\hline \multicolumn{6}{|l|}{ HEU-MET-FAST-024 } \\
\hline 1 (heumt092) & 0.9990 & 0.0015 & 0.9977 & 0.0011 & 7.55 \\
\hline \multicolumn{6}{|l|}{ HEU-MET-FAST-026 } \\
\hline b-1 (heumt099) & 0.9982 & 0.0042 & 1.0042 & 0.0014 & 4.86 \\
\hline b-2 (heumt100) & 0.9982 & 0.0042 & 0.9984 & 0.0014 & 5.42 \\
\hline$b-3$ (heumt 101 ) & 1 & 0.0038 & 0.9988 & 0.0016 & 8.39 \\
\hline b-4 (heumt 102) & 1 & 0.0038 & 0.9977 & 0.0019 & 9.94 \\
\hline b-5 (heumt 103) & 1 & 0.0038 & 0.9938 & 0.0016 & 10.18 \\
\hline b-6 (heumt 104) & 0.9982 & 0.0042 & 0.9977 & 0.0014 & 4.89 \\
\hline b-7 (heumt 105) & 0.9982 & 0.0042 & 0.9968 & 0.0016 & 5.44 \\
\hline b-8 (heumt 106) & 1 & 0.0038 & 0.9990 & 0.0018 & 8.56 \\
\hline b-9 (heumt 107) & 1 & 0.0038 & 0.9968 & 0.0017 & 10.12 \\
\hline $\mathrm{b}-10$ (heumt 108) & 1 & 0.0038 & 0.9927 & 0.0018 & 10.29 \\
\hline $\mathrm{c}-1$ (heumt 109) & 0.9982 & 0.0042 & 0.9981 & 0.0013 & 4.86 \\
\hline$c-2$ (heumtl 10) & 0.9982 & 0.0042 & 0.9959 & 0.0013 & 4.86 \\
\hline $\mathrm{c}-3$ (heumt111) & 0.9982 & 0.0042 & 0.9977 & 0.0015 & 5.39 \\
\hline $\mathrm{c}-4$ (heumt 112 ) & 1 & 0.0038 & 1.0004 & 0.0017 & 6.88 \\
\hline c-5 (heumt113) & 1 & 0.0038 & 0.9973 & 0.0018 & 8.30 \\
\hline c-6 (heumt114) & 1 & 0.0038 & 0.9966 & 0.0016 & 9.69 \\
\hline $\mathrm{c}-7$ (heumt 115) & 1 & 0.0038 & 0.9993 & 0.0017 & 9.83 \\
\hline c-8 (heumt 116) & 0.9982 & 0.0042 & 0.9997 & 0.0014 & 4.90 \\
\hline c-9 (heumt I 17) & 0.9982 & 0.0042 & 0.9880 & 0.0015 & 5.45 \\
\hline$c-10$ (heumt 118$)$ & 1 & 0.0038 & 0.9962 & 0.0017 & 8.39 \\
\hline$c-11$ (heumt 119$)$ & 1 & 0.0038 & 1.0011 & 0.0018 & 9.72 \\
\hline $\mathrm{c}-12$ (heumt 120$)$ & 1 & 0.0038 & 1.0027 & 0.0017 & 9.84 \\
\hline$d-1$ (heumt 121) & 0.9982 & 0.0042 & 0.9989 & 0.0013 & 4.87 \\
\hline$d-2$ (heumt 122) & 0.9982 & 0.0042 & 0.9935 & 0.0015 & 5.40 \\
\hline d-3 (heumt123) & 1 & 0.0038 & 0.9959 & 0.0019 & 8.14 \\
\hline
\end{tabular}




\begin{tabular}{|c|c|c|c|c|c|}
\hline $\mathrm{d}-4$ (heumt124) & 1 & 0.0038 & 0.9966 & 0.0018 & 9.28 \\
\hline $\mathrm{d}-5$ (heumt 125) & 1 & 0.0038 & 0.9956 & 0.0018 & 9.44 \\
\hline $\mathrm{d}-6$ (heumt 126) & 0.9982 & 0.0042 & 0.9990 & 0.0015 & 4.92 \\
\hline $\mathrm{d}-7$ (heumt 127) & 0.9982 & 0.0042 & 0.9911 & 0.0014 & 5.44 \\
\hline
\end{tabular}

Table A-3. Parameters Used in Uranium Metal (Fast) Validation Calculations (Continued).

\begin{tabular}{|c|c|c|c|c|c|}
\hline $\begin{array}{c}\text { Experimental Descriptor } \\
\text { Case Number(Input File) }\end{array}$ & $\begin{array}{c}\text { Exp. } \\
\mathbf{k}_{\text {efr }}\end{array}$ & $\sigma_{\text {exp. }}$ & \multicolumn{3}{|c|}{ Calculated Results } \\
\hline & & & $\mathbf{k}_{\text {eff }}$ & $\sigma_{\mathrm{s}}$ & AEG (27gr) \\
\hline $\begin{array}{c}\text { HEU-MET-FAST-026 } \\
\text { (continued) }\end{array}$ & & & & & \\
\hline $\mathrm{d}-8$ (heumt128) & 1 & 0.0038 & 0.9970 & 0.0017 & 8.02 \\
\hline d-9 (heumt129) & 1 & 0.0038 & 0.9981 & 0.0017 & 9.23 \\
\hline d-10 (heumt130) & 1 & 0.0038 & 0.9990 & 0.0017 & 9.38 \\
\hline HEU-MET-FAST-033 & & & & & \\
\hline l (heumt93) & 0.9991 & 0.0014 & 0.9953 & 0.0004 & 8.63 \\
\hline 2(heumt94) & 0.9991 & 0.0014 & 0.9948 & 0.0004 & 10.93 \\
\hline HEU-MET-FAST-034 & & & & & \\
\hline I (heumt95) & 0.9990 & 0.0012 & 0.9923 & 0.0004 & 8.65 \\
\hline 2 (heumt96) & 0.9990 & 0.0012 & 0.9922 & 0.0004 & 8.75 \\
\hline 3 (heumt97) & 0.9990 & 0.0012 & 0.9954 & 0.0004 & 8.87 \\
\hline HEU-MET-FAST-036 & & & & & \\
\hline I (heumt98) & 0.9995 & 0.0013 & 0.9993 & 0.0004 & 10.97 \\
\hline IEU-MET-FAST-005 & & & & & \\
\hline I (ieumt001) & 1 & 0.0021 & 1.0138 & 0.0006 & 5.38 \\
\hline IEU-MET-FAST-006 & & & & & \\
\hline I (ieumt002) & 1 & 0.0023 & 0.9969 & 0.0006 & 5.32 \\
\hline
\end{tabular}


Page 78 of 87

Table A-4. Parameters Used in Uranium Metal (Thermal) Validation Calculations.

\begin{tabular}{|c|c|c|c|c|c|c|}
\hline $\begin{array}{c}\text { Experimental Descriptor } \\
\text { Case Number(Input File) }\end{array}$ & $\begin{array}{c}\text { Exp. } \\
k_{\text {eff }}\end{array}$ & $\sigma_{\text {exp. }}$ & \multicolumn{5}{|c|}{ Calculated Results } \\
\hline & & & $k_{\text {efr }}$ & $\sigma_{s}$ & AEG (18gr) & E (eV) \\
\hline $\begin{array}{c}\text { Research Reactor Fuel } \\
\text { HEU-MET-THERM-006 }\end{array}$ & & & & & & \\
\hline $1(1)$ & 1 & 0.0040 & 0.9979 & 0.0017 & 12.89 & 0.146 \\
\hline $2(2)$ & 1 & 0.0040 & 1.0007 & 0.0014 & 13.05 & 0.098 \\
\hline $3(3)$ & 1 & 0.0040 & 1.0074 & 0.0013 & 13.14 & 0.093 \\
\hline $4(4)$ & 1 & 0.0040 & 0.9969 & 0.0014 & 13.16 & 0.092 \\
\hline $5(5)$ & 1 & 0.0040 & 1.0047 & 0.0014 & 13.21 & 0.090 \\
\hline $6(6)$ & 1 & 0.0040 & 1.0002 & 0.0014 & 13.25 & 0.088 \\
\hline $7(7)$ & 1 & 0.0040 & 1.0003 & 0.0014 & 13.28 & 0.086 \\
\hline $8(8)$ & 1 & 0.0040 & 0.9945 & 0.0013 & 13.31 & 0.085 \\
\hline $9(9)$ & 1 & 0.0040 & 0.9955 & 0.0014 & 13.31 & 0.084 \\
\hline $10(10)$ & 1 & 0.0040 & 1.0059 & 0.0016 & 12.90 & 0.135 \\
\hline $11(11)$ & 1 & 0.0040 & 0.9987 & 0.0015 & 13.16 & 0.092 \\
\hline $12(12)$ & 1 & 0.0040 & 1.0066 & 0.0014 & 13.28 & 0.086 \\
\hline $13(13)$ & 1 & 0.0040 & 1.0302 & 0.0015 & 12.91 & 0.138 \\
\hline $16(16)$ & 1 & 0.0040 & 0.9974 & 0.0018 & 13.14 & 0.069 \\
\hline
\end{tabular}


Table A-5. Parameters Used in Uranium Solutions (HEU) Validation Calculations.

\begin{tabular}{|c|c|c|c|c|c|}
\hline \multirow[t]{2}{*}{$\begin{array}{l}\text { Experimental Descriptor } \\
\text { Case Number(Input File) }\end{array}$} & \multirow[t]{2}{*}{$\begin{array}{r}\text { Exp. } \\
k_{\text {efr }}\end{array}$} & \multirow[t]{2}{*}{$\sigma_{\text {exp. }}$} & \multicolumn{3}{|c|}{$\begin{array}{l}\text { Calculated Results } \\
\text { (all } k_{\text {eff }} \text { values normalized to Exp. values) }\end{array}$} \\
\hline & & & $\mathbf{k}_{\text {eff }}$ & $\sigma_{\mathrm{s}}$ & AEG (27gr) \\
\hline \multicolumn{6}{|l|}{ HEU-SOL-THERM-001 } \\
\hline 1 (heusl001) & $\mathrm{T}$ & 0.0025 & 1.0008 & 0.0020 & 23.58 \\
\hline 2 (heusl002) & 1 & 0.0025 & 1.0007 & 0.0020 & 21.69 \\
\hline 3 (heus1003) & 1 & 0.0025 & 1.0089 & 0.0020 & 23.61 \\
\hline 4 (heusl004) & 1 & 0.0025 & 1.0046 & 0.0022 & 21.58 \\
\hline 5 (heusl005) & 1 & 0.0025 & 1.0036 & 0.0017 & 24.57 \\
\hline 6 (heus1006) & 1 & 0.0025 & 1.0104 & 0.0019 & 24.52 \\
\hline 7 (heus1007) & 1 & 0.0025 & 1.0023 & 0.0020 & 23.66 \\
\hline 8 (heusl008) & 1 & 0.0025 & 1.0051 & 0.0021 & 23.58 \\
\hline 9 (heusl009) & 1 & 0.0025 & 0.9976 & 0.0022 & 21.59 \\
\hline 10 (heus1010) & 1 & 0.0025 & 0.9995 & 0.0018 & 24.46 \\
\hline \multicolumn{6}{|l|}{ HEU-SOL-THERM-002 } \\
\hline 1 (heusl011) & 1 & 0.0020 & 1.0093 & 0.0022 & 23.61 \\
\hline 2 (heusl012) & 1 & 0.0020 & 1.0113 & 0.0020 & 23.62 \\
\hline 3 (heusl013) & 1 & 0.0020 & 1.0008 & 0.0019 & 21.84 \\
\hline 4 (heus1014) & 1 & 0.0020 & 1.0083 & 0.0020 & 21.90 \\
\hline 5 (heusl015) & 1 & 0.0020 & 1.0058 & 0.0021 & 23.62 \\
\hline 6 (heusl016) & 1 & 0.0020 & 1.0125 & 0.0019 & 23.65 \\
\hline 7 (heus1017) & 1 & 0.0020 & 1.0040 & 0.0021 & 21.86 \\
\hline 8 (heus 1018 ) & 1 & 0.0020 & 1.0073 & 0.0020 & 21.94 \\
\hline 9 (heusl019) & 1 & 0.0020 & 1.0053 & 0.0019 & 24.52 \\
\hline 10 (heusl020) & 1 & 0.0020 & 1.0072 & 0.0016 & 24.53 \\
\hline I1 (heus1021) & 1 & 0.0020 & 1.0044 & 0.0020 & 23.62 \\
\hline 12 (heus 1022 ) & 1 & 0.0020 & 1.0131 & 0.0021 & 23.65 \\
\hline 13 (heus 1023 & 1 & 0.0020 & 1.0010 & 0.0021 & 21.86 \\
\hline 14 (heusl024) & 1 & 0.0020 & 1.0051 & 0.0022 & 21.97 \\
\hline \multicolumn{6}{|l|}{ HEU-SOL-THERM-003 } \\
\hline l(heus1025) & 1 & 0.0050 & 1.0039 & 0.0017 & 24.53 \\
\hline 2 (heus1026) & 1 & 0.0050 & 1.0047 & 0.0018 & 24.52 \\
\hline 3 (heus1027) & 1 & 0.0050 & $\$ .0041$ & 0.0019 & 23.59 \\
\hline 4 (heus1028) & 1 & 0.0050 & 1.0084 & 0.0020 & 23.63 \\
\hline 5 (heus1029) & 1 & 0.0050 & 1.0041 & 0.0021 & 21.78 \\
\hline 6 (heus1030) & 1 & 0.0050 & 1.0036 & 0.0021 & 21.89 \\
\hline 7 (heus1031) & 1 & 0.0050 & 1.0044 & 0.0016 & 24.54 \\
\hline 8 (heus1032) & 1 & 0.0050 & 1.0066 & 0.0021 & 23.60 \\
\hline 9 (heusl033) & 1 & 0.0050 & 1.0071 & 0.0020 & 23.66 \\
\hline 10 (heusl034) & 1 & 0.0050 & 0.9989 & 0.0022 & 21.80 \\
\hline 11 (heusl035) & $T$ & 0.0050 & 1.0055 & 0.0021 & 21.97 \\
\hline 12 (heusl036) & 1 & 0.0050 & 1.0077 & 0.0018 & 24.52 \\
\hline 13 (heus1037) & 1 & 0.0050 & 1.0033 & 0.0017 & 24.55 \\
\hline 14 (heusl038) & 1 & 0.0050 & 1.0058 & 0.0018 & 24.53 \\
\hline 15 (heus1039) & 1 & 0.0050 & 0.9921 & 0.0017 & 24.48 \\
\hline 16 (heusl040) & 1 & 0.0050 & 1.0044 & 0.0021 & 23.60 \\
\hline 17 (heusl041) & 1 & 0.0050 & 1.0096 & 0.0019 & 23.69 \\
\hline 18 (heusl042) & 1 & 0.0050 & 0.9985 & 0.0021 & 21.80 \\
\hline 19 (heus1043) & 1 & 0.0050 & 1.0087 & 0.0020 & 22.01 \\
\hline
\end{tabular}


Table A-5. Parameters Used in Uranium Solutions (HEU) Validation Calculations (Continued).

\begin{tabular}{|c|c|c|c|c|c|}
\hline \multirow[t]{2}{*}{$\begin{array}{l}\text { Experimental Descriptor } \\
\text { Case Number(Input File) }\end{array}$} & \multirow[t]{2}{*}{$\begin{array}{l}\text { Exp. } \\
k_{\text {eff }}\end{array}$} & \multirow[t]{2}{*}{$\sigma_{\text {exp. }}$} & \multicolumn{3}{|c|}{$\begin{array}{c}\text { Calculated Results } \\
\text { (all } k_{\text {eff }} \text { values normalized to Exp. values) }\end{array}$} \\
\hline & & & $k_{\text {eff }}$ & $\sigma_{\mathrm{s}}$ & AEG (27gr) \\
\hline \multicolumn{6}{|l|}{ HEU-SOL-THERM-007 } \\
\hline I (heusl044) & 1 & 0.0030 & 1.0134 & 0.0015 & 24.42 \\
\hline 2 (heus1045) & 1 & 0.0030 & 1.0168 & 0.0017 & 21.74 \\
\hline 3 (heus1046) & 1 & 0.0030 & 1.0082 & 0.0015 & 24.46 \\
\hline 4 (heus1047) & 1 & 0.0030 & 1.0108 & 0.0018 & 21.92 \\
\hline 5 (heus1048) & 1 & 0.0030 & 1.0092 & 0.0017 & 24.33 \\
\hline 6 (heus1049) & 1 & 0.0030 & 1.0096 & 0.0019 & 21.71 \\
\hline 7 (heus1050) & 1 & 0.0030 & 1.0075 & 0.0017 & 24.35 \\
\hline 8 (heusl051) & 1 & 0.0030 & 1.0008 & 0.0020 & 21.73 \\
\hline 9 (heusl052) & 1 & 0.0030 & 1.0084 & 0.0018 & 24.30 \\
\hline 10 (heusl053) & 1 & 0.0030 & 1.0141 & 0.0016 & 24.25 \\
\hline 11 (heus1054) & 1 & 0.0030 & 1.0115 & 0.0018 & 21.81 \\
\hline 12 (heus 1055 ) & 1 & 0.0030 & 1.0080 & 0.0015 & 24.30 \\
\hline 13 (heusl056) & 1 & 0.0030 & 1.0096 & 0.0019 & 21.97 \\
\hline 14 (heus 1057 ) & 1 & 0.0030 & 1.0067 & 0.0019 & 21.92 \\
\hline 15 (heusl058) & $T$ & 0.0035 & 1.0080 & 0.0018 & 21.90 \\
\hline 16 (heus 1059 ) & 1 & 0.0035 & 1.0075 & 0.0019 & 21.82 \\
\hline 17 (heusl060) & 1 & 0.0035 & 1.0083 & 0.0018 & 21.91 \\
\hline \multicolumn{6}{|l|}{ HEU-SOL-THERM-008 } \\
\hline 1 (heusl061) & 1 & 0.0035 & 1.0026 & 0.0016 & 24.52 \\
\hline 2 (heus1062) & 1 & 0.0035 & 1.0122 & 0.0019 & 21.95 \\
\hline 3 (heusl063) & 1 & 0.0035 & 0.9958 & 0.0016 & 24.56 \\
\hline 4 (heus1064) & 1 & 0.0035 & 1.0072 & 0.0017 & 22.13 \\
\hline 5 (heus 1065 ) & 1 & 0.0035 & 1.0002 & 0.0016 & 24.52 \\
\hline 6 (heus1066) & 1 & 0.0035 & 1.0084 & 0.0018 & 21.82 \\
\hline 7 (heus1067) & 1 & 0.0035 & 0.9975 & 0.0017 & 24.55 \\
\hline 8 (heusi068) & 1 & 0.0035 & 1.0026 & 0.0018 & 21.89 \\
\hline 9 (heusl069) & 1 & 0.0035 & 1.0006 & 0.0015 & 24.52 \\
\hline 10 (heusl070) & 1 & 0.0035 & 1.0088 & 0.0019 & 21.96 \\
\hline 11 (heus1071) & 1 & 0.0035 & 0.9961 & 0.0015 & 24.58 \\
\hline 12 (heusi072) & 1 & 0.0035 & 1.0048 & 0.0018 & 22.17 \\
\hline 13 (heusl073) & 1 & 0.0035 & 1.0073 & 0.0018 & 21.98 \\
\hline 14 (heus1074) & 1 & 0.0035 & 1.0057 & 0.0017 & 22.13 \\
\hline \multicolumn{6}{|l|}{ HEU-SOL-THERM-009 } \\
\hline 1 (heus1075) & 1 & 0.0057 & 1.0037 & 0.0017 & 20.73 \\
\hline 2 (heus1076) & 1 & 0.0057 & 1.0061 & 0.0016 & 21.47 \\
\hline 3 (heus1078) & 1 & 0.0057 & 1.0072 & 0.0016 & 22.55 \\
\hline $4($ heus 1079$)$ & 1 & 0.0057 & 1.0021 & 0.0016 & 23.42 \\
\hline \multicolumn{6}{|l|}{ HEU-SOL-THERM-011 } \\
\hline $1($ heusl080) & 1 & 0.0019 & 1.0119 & 0.0013 & 24.69 \\
\hline 2 (heus1081) & 1 & 0.0019 & 1.0042 & 0.0014 & 24.70 \\
\hline
\end{tabular}


Table A-5. Parameters Used in Uranium Solutions (HEU) Validation Calculations (Continued).

\begin{tabular}{|c|c|c|c|c|c|}
\hline $\begin{array}{c}\text { Experimental Descriptor } \\
\text { Case Number(Input File) }\end{array}$ & $\begin{array}{c}\text { Exp. } \\
\mathbf{k}_{\text {eff }}\end{array}$ & $\sigma_{\text {exp. }}$ & \multicolumn{3}{|c|}{$\begin{array}{c}\text { Calculated Results } \\
\text { (all } \mathbf{k}_{\text {eff }} \text { values normalized to Exp. values) }\end{array}$} \\
\hline HEU-SOL-THERM-012 & & & $\mathbf{k}_{\text {eff }}$ & $\sigma_{\mathrm{s}}$ & AEG (27gr) \\
\hline I (heus1082) & 0.9999 & 0.0058 & 1.0042 & 0.0009 & 24.99 \\
\hline HEU-SOL-THERM-010 & & & & & \\
\hline 1 (heus1083) & 1 & 0.0018 & 1.0066 & 0.0015 & 24.26 \\
\hline 2 (heus1084) & 1 & 0.0018 & 1.0074 & 0.0014 & 24.24 \\
\hline 3 (heus1085) & 1 & 0.0018 & 1.0041 & 0.0015 & 24.18 \\
\hline 4 (heus1086) & 1 & 0.0018 & 1.0022 & 0.0015 & 24.16 \\
\hline
\end{tabular}


Table A-6. Parameters Used in Uranium Compounds Validation Calculations.

\begin{tabular}{|c|c|c|c|c|c|c|}
\hline \multirow[t]{2}{*}{$\begin{array}{l}\text { Experimental Descriptor } \\
\text { Case Number(Input File) }\end{array}$} & \multirow[t]{2}{*}{$\begin{array}{l}\text { Exp. } \\
k_{\text {err }}\end{array}$} & \multirow[t]{2}{*}{$\sigma_{\text {exp. }}$} & \multicolumn{4}{|c|}{$\begin{array}{l}\text { Calculated Results } \\
\text { (all } k_{\mathrm{eff}} \text { values normalized to Exp. values) }\end{array}$} \\
\hline & & & $k_{\text {eff }}$ & $\sigma_{s}$ & AEG (27 gr) & $\mathrm{H} / \mathrm{U}$ \\
\hline \multicolumn{7}{|l|}{ LEU-COMP-THERM-001 } \\
\hline$I($ Leum0101) & 0.9998 & 0.0030 & 0.9975 & 0.0017 & 23.56 & 399 \\
\hline 2 (Leum0102) & 0.9998 & 0.0030 & 0.9984 & 0.0016 & 23.57 & 399 \\
\hline $3($ Leum0103) & 0.9998 & 0.0030 & 0.9963 & 0.0016 & 23.57 & 399 \\
\hline 4 (Leum0104) & 0.9998 & 0.0030 & 0.9967 & 0.0017 & 23.57 & 399 \\
\hline 5 (Leum0105) & 0.9998 & 0.0030 & 0.9928 & 0.0015 & 23.58 & 399 \\
\hline 6 (Leum0106) & 0.9998 & 0.0030 & 0.9985 & 0.0017 & 23.57 & 399 \\
\hline 7 (Leum0107) & 0.9998 & 0.0031 & 0.9955 & 0.0015 & 23.61 & 399 \\
\hline $8($ Leum0108) & 0.9998 & 0.0030 & 0.9951 & 0.0015 & 23.59 & 399 \\
\hline \multicolumn{7}{|l|}{ LEU-COMP-THERM-002 } \\
\hline 1 (Leum0201) & 0.9997 & 0.0020 & 0.9954 & 0.0018 & 23.3 & 256 \\
\hline 2 (Leum 0202) & 0.9997 & 0.0020 & 1.0010 & 0.0016 & 23.31 & 256 \\
\hline 3 (Leum0203) & 0.9997 & 0.0020 & 0.9953 & 0.0019 & 23.31 & 256 \\
\hline 4 (Leum0204) & 0.9997 & 0.0018 & 0.9946 & 0.0017 & 23.33 & 256 \\
\hline 5 (Leum0205) & 0.9997 & 0.0019 & 0.9955 & 0.0020 & 23.34 & 256 \\
\hline \multicolumn{7}{|l|}{ LEU-COMP-THERM-010 } \\
\hline 1 (Leum 1001) & 1.0000 & 0.0021 & 1.0061 & 0.0020 & 23.23 & 256 \\
\hline 2 (Leum 1002) & 1.0000 & 0.0021 & 1.0082 & 0.0017 & 23.27 & 256 \\
\hline 3 (Leum I003) & 1.0000 & 0.0021 & 1.0037 & 0.0017 & 23.30 & 256 \\
\hline 4 (Leum 1004) & 1.0000 & 0.0021 & 0.9954 & 0.0016 & 23.35 & 256 \\
\hline 9 (Leum 1009) & 1.0000 & 0.0021 & 1.0006 & 0.0018 & 23.19 & 256 \\
\hline $10($ Leum 1010$)$ & 1.0000 & 0.0021 & 0.9999 & 0.0018 & 23.24 & 256 \\
\hline 11 (Leum 1011) & 1.0000 & 0.0021 & 1.0027 & 0.0019 & 23.27 & 256 \\
\hline 12 (Leum 1012$)$ & 1.0000 & 0.0021 & 1.0037 & 0.0019 & 23.31 & 256 \\
\hline 13 (Leum 1013) & 1.0000 & 0.0021 & 0.9976 & 0.0020 & 23.35 & 256 \\
\hline 14 (Leum 1014) & 1.0000 & 0.0028 & 0.9980 & 0.0018 & 21.84 & 106 \\
\hline 15 (Leum 1015) & 1.0000 & 0.0028 & 1.0005 & 0.0020 & 21.91 & 106 \\
\hline 16 (Leum 1016) & 1.0000 & 0.0028 & 1.0054 & 0.0019 & 21.95 & 106 \\
\hline $17($ Leum 1017) & 1.0000 & 0.0028 & 1.0054 & 0.0019 & 21.98 & 106 \\
\hline 18 (Leum 1018) & 1.0000 & 0.0028 & 1.0033 & 0.0021 & 22.00 & 106 \\
\hline 19 (Leum 1019) & 1.0000 & 0.0028 & 0.9952 & 0.0021 & 22.05 & 106 \\
\hline 20 (Leum 1020) & 1.0000 & 0.0028 & 1.0024 & 0.0019 & 21.89 & 106 \\
\hline 21 (Leum 1021) & 1.0000 & 0.0028 & 1.0028 & 0.0021 & 21.96 & 106 \\
\hline 22 (Leum 1022) & 1.0000 & 0.0028 & 1.0039 & 0.0021 & 22.03 & 106 \\
\hline 23 (Leum 1023) & 1.0000 & 0.0028 & 0.9961 & 0.0020 & 22.05 & 106 \\
\hline \multicolumn{7}{|l|}{ LEU-COMP-THERM-017 } \\
\hline 1 (Leum 1701) & 1.0000 & 0.0031 & 1.0025 & 0.0017 & 23.53 & 399 \\
\hline 2 (Leum 1702) & 1.0000 & 0.0031 & 1.0021 & 0.0018 & 23.56 & 399 \\
\hline 3 (Leum1703) & 1.0000 & 0.0031 & 1.0007 & 0.0016 & 23.56 & 399 \\
\hline $10($ Leum 1710) & 1.0000 & 0.0031 & 0.9957 & 0.0016 & 23.50 & 399 \\
\hline 11 (Leum 1711) & 1.0000 & 0.0031 & 0.9986 & 0.0016 & 23.54 & 399 \\
\hline 12 (Leum 1712) & 1.0000 & 0.0031 & 0.9958 & 0.0013 & 23.56 & 399 \\
\hline 13 (Leum 1713) & 1.0000 & 0.0031 & 0.9969 & 0.0015 & 23.57 & 399 \\
\hline 14 (Leum1714) & 1.0000 & 0.0031 & 0.9978 & 0.0016 & 23.58 & 399 \\
\hline 15 (Leum 1715) & 1.0000 & 0.0028 & 0.9923 & 0.0017 & 22.69 & 219 \\
\hline $16($ Leum 1716) & 1.0000 & 0.0028 & 0.9929 & 0.0017 & 22.74 & 219 \\
\hline 17 (Leum 1717) & 1.0000 & 0.0028 & 0.9984 & 0.0015 & 22.79 & 219 \\
\hline
\end{tabular}


Table A-6. Parameters Used in Uranium Compounds Validation Calculations (Continued).

\begin{tabular}{|c|c|c|c|c|c|c|}
\hline \multirow[t]{2}{*}{$\begin{array}{l}\text { Experimental Descriptor } \\
\text { Case Number(Input File) }\end{array}$} & \multirow[t]{2}{*}{$\begin{array}{l}\text { Exp. } \\
k_{\text {err }}\end{array}$} & \multirow[t]{2}{*}{$\sigma_{\text {exp. }}$} & \multicolumn{4}{|c|}{$\begin{array}{l}\text { Calculated Results } \\
\text { (all } k_{\text {eff }} \text { values normalized to Exp. values) }\end{array}$} \\
\hline & & & $k_{\text {eff }}$ & $\sigma_{s}$ & AEG (27 gr) & $\mathrm{H} / \mathrm{U}$ \\
\hline $\begin{array}{l}\text { LEU-COMP-THERM-017 } \\
\text { (continued) }\end{array}$ & & & & & & \\
\hline $18($ Leum 1718) & 1.0000 & 0.0028 & 0.9987 & 0.0016 & 22.79 & 219 \\
\hline 19 (Leum 1719) & 1.0000 & 0.0028 & 1.0001 & 0.0018 & 22.82 & 219 \\
\hline $20($ Leum 1720$)$ & 1.0000 & 0.0028 & 0.9948 & 0.0017 & 22.83 & 219 \\
\hline 21 (Leum 1721) & 1.0000 & 0.0028 & 0.9958 & 0.0017 & 22.85 & 219 \\
\hline 22 (Leum 1722) & 1.0000 & 0.0028 & 0.9933 & 0.0016 & 22.85 & 219 \\
\hline 23 (Leum 1723) & 1.0000 & 0.0028 & 0.9981 & 0.0016 & 22.75 & 219 \\
\hline 24 (Leum 1724) & 1.0000 & 0.0028 & 1.0017 & 0.0016 & 22.80 & 219 \\
\hline 25 (Leum 1725) & 1.0000 & 0.0028 & 0.9948 & 0.0017 & 22.87 & 219 \\
\hline
\end{tabular}


Table A-7. Parameters Used in Uranium Solutions (LEU) Validation Calculations.

\begin{tabular}{|c|c|c|c|c|c|c|}
\hline \multirow[t]{2}{*}{$\begin{array}{l}\text { Experimental Descriptor } \\
\text { case Number(Input File) }\end{array}$} & \multirow[t]{2}{*}{$\begin{array}{l}\text { Exp. } \\
k_{\text {efr }}\end{array}$} & \multirow[t]{2}{*}{$\sigma_{\text {exp }}$} & \multicolumn{4}{|c|}{$\begin{array}{l}\text { Calculated Results } \\
\text { (all } k_{\text {eff }} \text { values normalized to Exp. values) }\end{array}$} \\
\hline & & & $\mathbf{k}_{\text {eff }}$ & $\sigma_{\mathrm{s}}$ & AEG (27 gr) & $\mathrm{H} / \mathrm{U}$ \\
\hline \multicolumn{7}{|l|}{ LEU-SOL-THERM-001 } \\
\hline $1($ Solm 101$)$ & 0.9991 & 0.0029 & 1.0141 & 0.0010 & 24.15 & 454 \\
\hline \multicolumn{7}{|l|}{ LEU-SOL-THERM-002 } \\
\hline $1($ Solm201) & 1.0038 & 0.0040 & 0.9969 & 0.0011 & 24.78 & 1098 \\
\hline $2($ Solm202) & 1.0024 & 0.0037 & 0.9945 & 0.0013 & 24.72 & 1002 \\
\hline $3($ Solm 203$)$ & 1.0024 & 0.0044 & 0.9974 & 0.0012 & 24.75 & 1002 \\
\hline \multicolumn{7}{|l|}{ LEU-SOL-THERM-003 } \\
\hline $1($ Solm301) & 0.9997 & 0.0039 & 0.9998 & 0.0014 & 24.67 & 771 \\
\hline 2 (Solm302) & 0.9993 & 0.0042 & 0.9986 & 0.0013 & 24.74 & 878 \\
\hline $3($ Solm 303$)$ & 0.9995 & 0.0042 & 1.0008 & 0.0013 & 24.75 & 898 \\
\hline 4 (Solm 304) & 0.9995 & 0.0042 & 0.9959 & 0.0013 & 24.76 & 914 \\
\hline 5 (Solm305) & 0.9997 & 0.0048 & 0.9973 & 0.0011 & 24.86 & 1173 \\
\hline $6($ Solm306) & 0.9999 & 0.0049 & 0.9988 & 0.0010 & 24.87 & 1214 \\
\hline 7 (Solm307) & 0.9994 & 0.0049 & 0.9978 & 0.0010 & 24.88 & 1241 \\
\hline 8 (Solm308) & 0.9993 & 0.0052 & 1.0020 & 0.0009 & 24.93 & 1400 \\
\hline $9($ Solm309) & 0.9996 & 0.0052 & 0.9987 & 0.0009 & 24.93 & 1438 \\
\hline \multicolumn{7}{|l|}{ LEU-SOL-THERM-004 } \\
\hline 1 (Leu401) & 0.9994 & 0.0008 & 1.0039 & 0.0013 & 24.64 & 719 \\
\hline 29 (Leu402) & 0.9999 & 0.0009 & 0.9945 & 0.0013 & 24.68 & 772 \\
\hline 33 (Leu403) & 0.9999 & 0.0009 & 0.9893 & 0.0012 & 24.72 & 843 \\
\hline 34 (Leu404) & 0.9999 & 0.0010 & 0.9958 & 0.0012 & 24.75 & 896 \\
\hline 46 (Leu405) & 0.9999 & 0.0010 & 0.9952 & 0.0013 & 24.77 & 942 \\
\hline 51 (Leu406) & 0.9993 & 0.0010 & 0.9957 & 0.0012 & 24.79 & 983 \\
\hline 54 (Leu407) & 0.9996 & 0.0011 & 0.9932 & 0.0011 & 24.81 & 1018 \\
\hline
\end{tabular}




\section{APPENDIX B: Comparison of WSRC and WSMS MCNP-4B Validation Results}

MCNP-4B has been validated on the WSMS DEC Alpha machines in the Centennial Complex. Since this same version of the code will be run at WSRC on their RS/ 6000 workstations, it was desirable to determine if the validation that was performed for MCNP-4B on the WSMS platform could be used for the WSRC platform as well. In order to determine if this comparison could be used in support of the SRS MCNP-4B validation, a representative sample of input files from each of the major fissile types and forms were run under the SRS certified MCNP-4B code and subsequently compared to the validated WSMS certified MCNP-4B code. The results of these comparisons are shown in Table B.1, and demonstrate that the two platforms provide statistically similar $\mathrm{k}_{\mathrm{eff}}$ values; therefore, this appendix gives sufficient certification that the validation for MCNP-4B under the WSMS system is directly compatible as the MCNP-4B validation for the WSRC system. The results are listed in the following table (DFS signifies the WSRC platform).

Table B-1. Results From SRS and WSMS MCNP-4B Comparison.

\begin{tabular}{|c|c|c|c|c|c|c|}
\hline & file & DFS & DFS & WSMS & WSMS & \\
\hline & & $\mathbf{k}_{\text {eff }}$ & $\sigma$ & $\mathbf{k}_{\text {eff }}$ & $\sigma$ & $\Delta \mathbf{k}$ \\
\hline & & & & & & \\
\hline 1 & heumt034.out & 0.9860 & 0.0013 & 0.9860 & 0.0013 & 0.0000 \\
\hline 2 & heumt037.out & 0.9877 & 0.0013 & 0.9888 & 0.0013 & -0.0011 \\
\hline 3 & heumt039.out & 0.9885 & 0.0014 & 0.9885 & 0.0014 & 0.0000 \\
\hline 4 & heumt043.out & 0.9903 & 0.0012 & 0.9903 & 0.0012 & 0.0000 \\
\hline 5 & heumt045.out & 0.9909 & 0.0012 & 0.9909 & 0.0012 & 0.0000 \\
\hline 6 & heumt046.out & 0.9908 & 0.0012 & 0.9908 & 0.0012 & 0.0000 \\
\hline 7 & heumt050.out & 0.9898 & 0.0010 & 0.9898 & 0.0010 & 0.0000 \\
\hline 8 & heumt057.out & 0.9878 & 0.0013 & 0.9874 & 0.0012 & 0.0004 \\
\hline 9 & heumt071.out & 0.9921 & 0.0006 & 0.9916 & 0.0006 & 0.0004 \\
\hline 10 & heumt117.out & 0.9854 & 0.0015 & 0.9862 & 0.0015 & -0.0008 \\
\hline 11 & heumt127.out & 0.9888 & 0.0015 & 0.9893 & 0.0014 & -0.0005 \\
\hline 12 & heus1004.out & 1.0046 & 0.0022 & 1.0046 & 0.0022 & 0.0000 \\
\hline 13 & heus1014.out & 1.0063 & 0.0020 & 1.0083 & 0.002 & -0.0020 \\
\hline 14 & heus1039.out & 0.9946 & 0.0017 & 0.9921 & 0.0017 & 0.0025 \\
\hline 15 & heusl050.out & 1.0057 & 0.0016 & 1.0075 & 0.0017 & -0.0019 \\
\hline 16 & heus1063.out & 0.9982 & 0.0016 & 0.9958 & 0.0016 & 0.0024 \\
\hline 17 & heusl071.out & 0.9957 & 0.0015 & 0.9961 & 0.0015 & -0.0004 \\
\hline 18 & heus1078.out & 1.0060 & 0.0016 & 1.0072 & 0.0016 & -0.0012 \\
\hline 19 & heus1084.out & 1.0074 & 0.0014 & 1.0074 & 0.0014 & 0.0000 \\
\hline 20 & heus1087.out & 0.9990 & 0.0013 & 0.9990 & 0.0013 & 0.0000 \\
\hline 21 & heus1088.out & 0.9914 & 0.0013 & 0.9911 & 0.0014 & 0.0003 \\
\hline 22 & heus1089.out & 0.9934 & 0.0010 & 0.9951 & 0.0010 & -0.0017 \\
\hline 23 & heus1090.out & 0.9841 & 0.0010 & 0.9840 & 0.0010 & 0.0001 \\
\hline 24 & heus1091.out & 0.9983 & 0.0010 & 0.9972 & 0.0010 & 0.0011 \\
\hline 25 & heus1094.out & 0.9997 & 0.0009 & 0.9975 & 0.0009 & 0.0022 \\
\hline 26 & pu-mt006.out & 0.9802 & 0.0007 & 0.9817 & 0.0007 & -0.0015 \\
\hline & & & & & & \\
\hline
\end{tabular}


Table B-1. Results From SRS and WSMS MCNP-4B Comparison (Continued).

\begin{tabular}{|c|c|c|c|c|c|c|}
\hline & file & DFS & DFS & WSMS & WSMS & \\
\hline & & $k_{\text {efr }}$ & $\sigma$ & $\mathbf{k}_{\text {eff }}$ & $\sigma$ & $\Delta k$ \\
\hline & & & & & & \\
\hline 27 & pu-mt008.out & 0.9951 & 0.0013 & 0.9954 & 0.0013 & -0.0003 \\
\hline 28 & pu-mt009.out & 0.9951 & 0.0013 & 0.9933 & 0.0012 & 0.0018 \\
\hline 29 & pu-mt01 l.out & 1.0003 & 0.0008 & 1.0003 & 0.0008 & 0.0000 \\
\hline 30 & pu-mt012.out & 0.9949 & 0.0012 & 0.9949 & 0.0012 & 0.0000 \\
\hline 31 & pu-mt013.out & 0.9932 & 0.0012 & 0.9924 & 0.0013 & 0.0008 \\
\hline 32 & pu-mt014.out & 0.9935 & 0.0012 & 0.9935 & 0.0012 & 0.0000 \\
\hline 33 & pu-mt015.out & 0.9929 & 0.0012 & 0.9935 & 0.0012 & -0.0006 \\
\hline 34 & pu-mt016.out & 0.9933 & 0.0011 & 0.9933 & 0.0011 & 0.0000 \\
\hline 35 & pu-mt029.out & 0.9939 & 0.0013 & 0.9935 & 0.0012 & 0.0004 \\
\hline 36 & pu-s1078.out & 1.0039 & 0.0012 & 1.0039 & 0.0012 & -0.0001 \\
\hline 37 & pu-s1084.out & 1.0046 & 0.0012 & 1.0044 & 0.0012 & 0.0002 \\
\hline 38 & pu-s1088.out & 1.0020 & 0.0012 & 1.0033 & 0.0012 & -0.0014 \\
\hline 39 & pu-s1089.out & 1.0024 & 0.0012 & 1.0024 & 0.0012 & 0.0000 \\
\hline 40 & pu-sl090.out & 1.0060 & 0.0012 & 1.0054 & 0.0012 & 0.0005 \\
\hline 41 & pu_s1009.out & 1.0015 & 0.0011 & 1.0006 & 0.0012 & 0.0009 \\
\hline 42 & pu_sl011.out & 1.0029 & 0.0012 & 1.0029 & 0.0012 & 0.0000 \\
\hline 43 & pu sl012.out & 1.0002 & 0.0012 & 1.0002 & 0.0012 & 0.0000 \\
\hline 44 & pu_slo13.out & 1.0110 & 0.0010 & 1.0110 & 0.0010 & 0.0000 \\
\hline 45 & pu_s1059.out & 1.0057 & 0.0019 & 1.0072 & 0.0012 & -0.0015 \\
\hline 46 & l.out (MTR) & 0.9982 & 0.0015 & 0.9979 & 0.0017 & 0.0003 \\
\hline 47 & 2.out (MTR) & 1.0044 & 0.0016 & 1.0007 & 0.0014 & 0.0037 \\
\hline 48 & 4.out (MTR) & 0.9964 & 0.0016 & 0.9969 & 0.0014 & -0.0005 \\
\hline 49 & 5.out (MTR) & 1.0055 & 0.0015 & 1.0047 & 0.0014 & 0.0008 \\
\hline 50 & 6.out (MTR) & 1.0007 & 0.0014 & 1.0002 & 0.0014 & 0.0006 \\
\hline 51 & 7.out (MTR) & 0.9987 & 0.0014 & 1.0003 & 0.0014 & -0.0016 \\
\hline 52 & 8.out (MTR) & 0.9959 & 0.0015 & 0.9945 & 0.0013 & 0.0014 \\
\hline & Mean & 0.9968 & 0.0013 & 0.9967 & 0.0013 & \\
\hline & $\begin{array}{l}\text { Std. Deviation } \\
\text { About Mean }\end{array}$ & 0.0070 & 0.0003 & 0.0070 & 0.0003 & \\
\hline
\end{tabular}

Given that the means and the standard deviations are so close (small differences in the $4^{\text {th }}$ decimal place), and that the bias/bias uncertainties determined in the WSMS validation documents are only reported to three decimal places, the WSMS validation results and the WSRC validation results would be the same. This is due to the fact that a lower tolerance limit is calculated by the equation :

$K_{L}=\left(\right.$ Mean $\left.K_{e f f}\right)-U S_{P}$

where $U$ is a constant (one-sided lower tolerance factor) and $S_{p}$ is the square root of the pooled variance. $\mathrm{S}_{\mathrm{p}}$ is given by:

$\mathrm{S}_{\mathrm{p}}=\sqrt{(s)^{2}+(\sigma)^{2}}$ 
where $\mathrm{s}^{2}$ is the variance (standard deviation) about the mean squared, and $\sigma^{2}$ is the average uncertainty squared. As seen in Table B-1, all of these values are the same between the WSRC and WSMS data, except for the mean $\mathrm{K}_{\mathrm{eff}}$, which is within one unit of the fourth decimal place. This insignificant difference would vanish due to the truncation of the fourth decimal place when LTL values are reported, yielding the same result.

In conclusion, the above results of the subset comparisons prove that the WSMS MCNP$4 B$ validation serves as an effective validation of the WSRC certified MCNP-4B code, in addition to providing correct and accurate bias and bias uncertainty. 